QK
541.5 - G72 


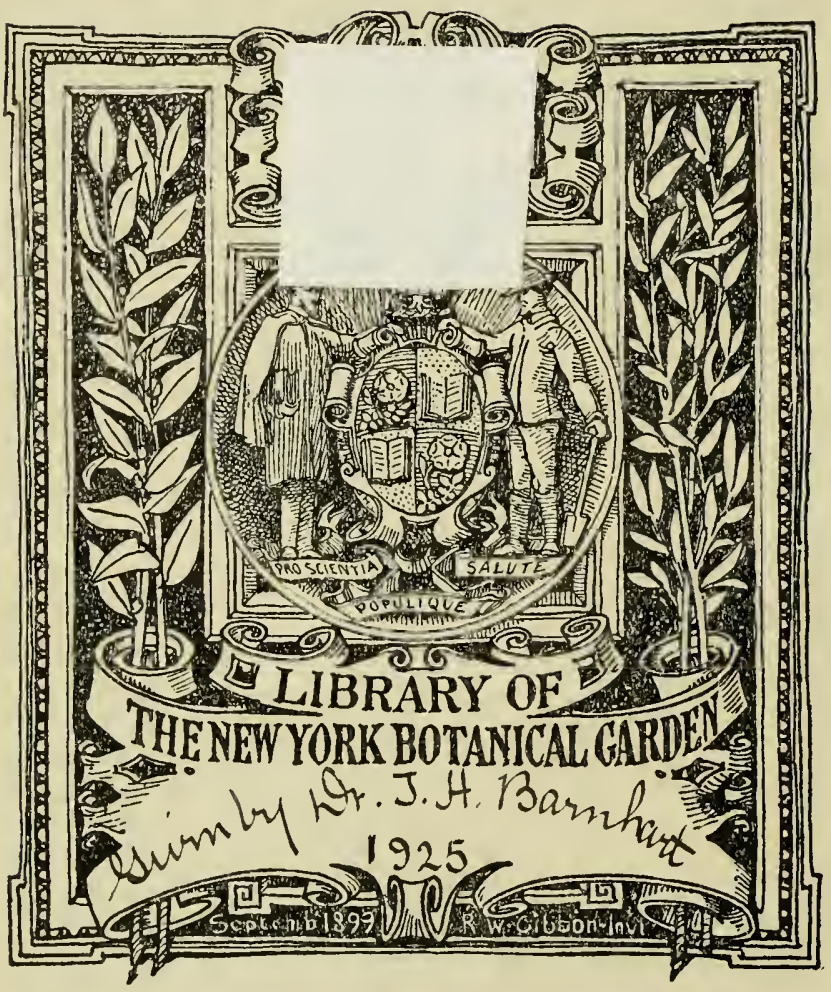






\section{The Moss Flora of New York City and Vicinity \\ GROUT}



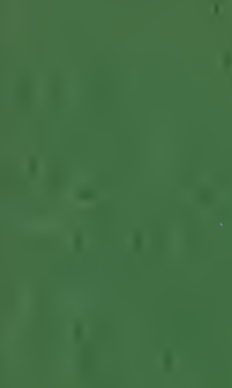

(1)
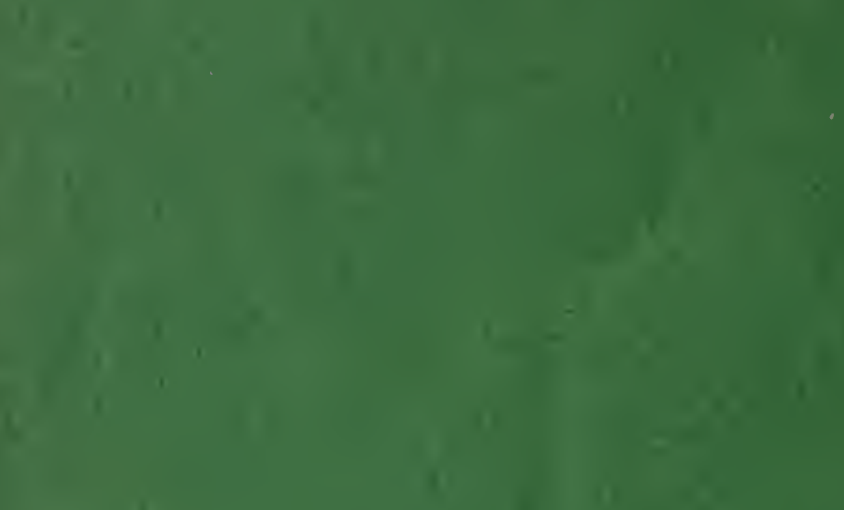

\section{2.}
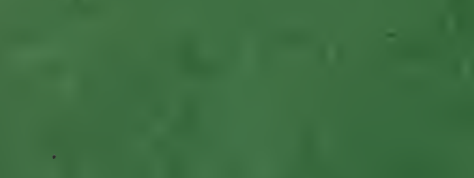

$=$

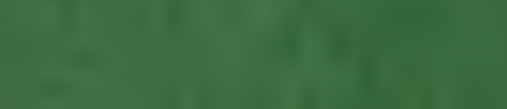

1
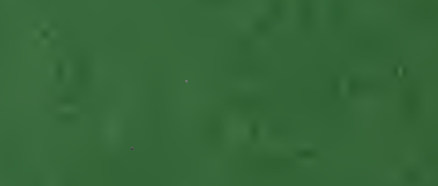

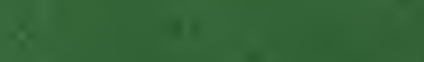

104 1.

1

(1)
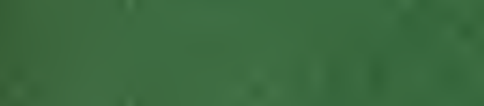

1

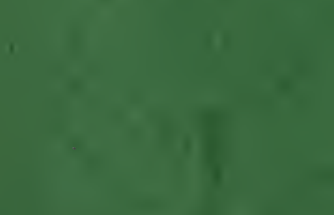

n

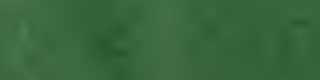




\title{
The Moss Flora of New York City and Vicinity
}

BY

\author{
A. J. GROUT, Ph.D.
}

CHAIRMAN DEPARTMENT OF NATURAL SCIENCES, CURTIS HIGH SCHOOL, BOROUGH OF RICHMOND, NEW YORK CITY

\author{
1.MMREY \\ NEW YORK \\ BOTANICAL \\ (IAR?ZIN
}

F UBLISHED BY THE AUTHOR

NEW DORP, N. Y.

OCT. 1916 


$$
\begin{aligned}
& 6 \pi 5 \% 1, \\
& \begin{array}{l}
111 \\
4+2=
\end{array}
\end{aligned}
$$

PRESS OH

STEINMAN \& FOLTZ,

LANCASTER, PA. 


\section{PREFACE}

Although New York City is one of the principal botanical centers of the United States and of the world and has an institution within its borders that has paid special attention to bryophytes, I know of no formal list of its moss flora; I believe none has been published.

On the other hand, materials for such a list are abundant and the large number of people in the city interested in science, either as a profession or diversion, will certainly give a wide field of usefulness to a carefully prepared list arranged in a helpful manner. Such a list will also stimulate investigation into our rapidly vanishing moss flora, and put on scientific record facts of natural history that will soon have vanished beyond the possibility of record or recall.

Probably no other region in the country has had so careful a bryological survey as the late C. F. Austin made of that part of New Jersey lying around Closter. In New Jersey the mosses of the North and those of the South meet, and it seems to one who scans Austin's work with care that he found there almost all the mosses of Eastern North America. Any one who can now duplicate ninety fer cent. of his collections in this region may reckon himself a past master in collecting, and one who discovers a moss in this region that Austin overlooked can congratulate himself on his luck.

The area to be included in this list is not to be defined clearly and definitely. All counties of New York and New Jersey lying adjacent to the city are of course included. In the main, localities outsicle this will te given only for rare or unusual mosses that do not occur within these limits or are very infrequent. An exception will be mace in the case of Long Island, as all available information concerning that area will be included.

For fifteen years the author has made a careful study, in the field, of the mosses of eastern Long Island and of Staten Island, in addition to the work already done by others whose names are 
given in the body of the text. Most of the data from the Bronx northward have been obtained from the collections of the New York Botanical Garden.

The author hopes that collectors and others who have or acquire additional information concerning the moss flora of New York City and vicinity will communicate it to him in order to have all available facts collated for scientific record and use.

In many ways it would have been preferable to have a work of this kind published and distributed by some one of the local scientific societies, but as insufficient funds were reported available the author has undertaken both the labor and expense of this issue.

The author knows very little about the Sphagna and the list of that genus is frankly a compilation.

Curtis High School, Staten Island, N. Y., Oct. IgI6. 


\section{INTRODUCTION}

As stated in the preface, in and around New York City the moss flora of the North and of the South meet and mingle, and the number of species occurring is large, varied, and interesting. Along the coast we find such species as Pogonatum brachyphyllum, Raphidostegium adnatum, and Plagiothecium micans, which seem to reach their maximum development in the South Atlantic States. In northern Long Island and in the Palisades and mountains of New Jersey we find species like Hypnum Crista-castrensis, Thamnium alleghaniense, Sciaromium Lescurii, and Andreaea petrophila, which are characteristic of the mountains and deep cool woods of the North.

A very noticeable fact about the moss flora of this region is the lack of tree-growing forms such as Orthotrichum and Pylaisia in the immediate vicinity of the city, Thelia being almost the only moss found on tree trunks above a few inches from the base. Mrs. Britton reports four species of Orthotrichum from New Dorp, but in seven years' careful search I have been unable to discover a single specimen.

As one gets away from the city these mosses begin to appear in normal quantities. For this reason the author is inclined to believe that the gases produced in the city are the cause of this marked absence of arboreal mosses.

No attempt is made to give a full list of localities from which the more common species have been collected. It would add materially to the labor and expense of the work and little to its practical usefulness. In the case of rare or infrequent species not only the locality of collection but the location of authentic specimens is given.

! means that the author has seen the specimen.

!! means that the author has a specimen in his collection and unless otherwise stated the specimen has been collected by him.

Numbers in parenthesis indicate specimens in the collections of the Brooklyn Institute Museum. 
H. S. indicates specimens in the herbarium of the Long Island Historical Society, now in charge of the Brooklyn Botanic Garden.

To save space the following abbreviations have been used:

"E. G. B.," for Mrs. E. G. Britton.

"R. S. W.," for R. S. Williams.

"Sanial," for Miss Marie L. Sanial.

"Hulst," for the late Rev. Geo. D. Hulst.

"Latham," for citations from the list of mosses published in the Flora of Southold and Gardiner's Island by S. H. Burnham and Roy A. Latham in Torreya for November, I9I4.

"N. Am. Flora," for North American Flora, vol. I5, published by the New York Botanical Gardens.

"Bx!" means that the specimen is in the collections of the New York Botanical Gardens at Bronx Park.

"Flora N. J.," refers to Britton's Preliminary Catalogue of the Flora of New Jersey, Rutgers College, I88r. The mosses were listed almost exclusively from the collections of C. F. Austin.

"Flora L. Id.," refers to The Flora of Long Island by Smith Ely Jelliffe. Lancaster, Pa. $\mathbf{1 8 9 9 .}$

"Mosses S. Id.," refers to a Preliminary List of the Mosses of Staten Island by Elizabeth G. Britton. Proceedings of the Natural Science Association of Staten Island, Special No. Io, July, I 890 .

"Bry. Ct.," refers to the Bryophytes of Connecticut by Evans and Nichols.

"Geol. Survey, N. J.," refers to a list of mosses by E. A. Rau and E. G. Britton, published in the Geological Survey of New Jersey in 1889 . This also is founded on Austin's collections but differs in some respects from the earlier list by Britton.

The keys and descriptions are mostly taken from the author's two manuals, "Mosses with a Hand-lens," and "Mosses with Hand-lens and Microscope." The photographs are selected from a large number which are to appear in the third edition of "Mosses with a Hand-lens" now in preparation. The season when the spores mature is indicated in most cases by a word denoting the season. 


\section{CLASSIFIC ATION AND NOMENCLATURE}

$I$ have made as few changes in nomenclature as is consistent with clearness and a moderate interpretation of the necessities of the situation. The principle of priority has been allowed great weight, but usage also has its claims and a name long in common use has not been discarded unless convenience and clearness seemed to demand it.

The following is a synopsis of the system of classification followed:

\section{CLASS MUSCI}

ORDER I. SPHAGNALES

Family I. Sphagnaceae.
ORDER I1. ANDREAEALES

Family 2. Andrzaeaceae.

\section{ORDER 1II. BRYALES}

Suborder I. Nematodonteae

Family 3. Georgiaceae.

Family 4. Polytrichaceae.

Family 5. Buxbaumiaceae.

Suborder II. Arthrodonteae

Group 1. Apiolepidea-

Family 6. Archidiaceae.

Family 7. Dicranaceae.

Family 8. Leucobryaceae.

Family 9. Fissidentaceae.

Family ro. Grimmiaceae.

Family I . Tortulaceae.

Family 12. Encalyptaceae.

\section{Group 2. Diplolepide}

Subgroup Acrocarpae-

Family I3. Orthotrichaceae.

Family If. Splachnaceae.

Family 15. Funariaceae.

Family i6. Meesiaceae.

Family 17. Timmiaceae.

Family i8. Aulacomniaceae.

Family 19. Bartramiaceae.

Family 20. Bryaceae.

Subgroup Pleurocarpae-

Family 21 . Leskeaceae.

Family 22. Hypnaceae.

Family 23. Fabroniaceae.

Family 24. Neckeraceae.

Family 25. Leucodontaceae.

Family 26. Fontinalaceae.

Key to THE Fanilies of Mosses

I-Plants whitish or light gray, scarcely appearing green ........ 2

Plants green, yellow-green, or dark green to almost black....... 3

2-Plants of bogs; leaves with large colorless cells surrounded by narrow green cells; capsules nearly globular, ovoid when dry and

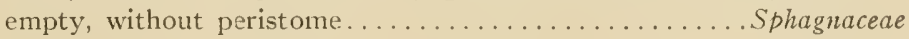


Plants of moist shady places, growing in dense tufts or cushions; leaves showing but one kind of cells (except in section); capsules

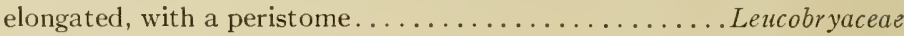

3-Leaves in two rows, with edges apparently towards the stem..... 4

Leaves in more than two rows, or if apparently two-ranked the edges of the leaves are not toward the stem ........... 5

4-Leaves apparently split on the inner edge and sheathing each other and the stem, costate; peristome present...........Fissidentaceae

Leaves ecostate, not split at base, but forming a continuous wing. margin along the stem in the sterile plants; peristome lacking.

Schistostegaceae*

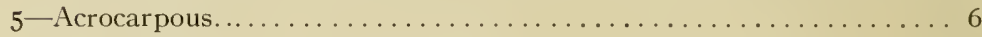

Pleurocarpous. . . . . . . . . . . . . . . . . .

6-Plants black or blackish green, except at top of growing stems; leaves with very thick cell-walls; growing on trees or rocks........7

Planțs green to light yellow-green, sometimes hoary, or, if blackish,

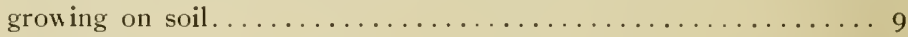

7-Capsule dehiscing by four valves, as in the Hepaticae, almost exclusively alpine or subalpine............... Andreaeaceae

Capsule dehiscing by an operculum; peristome of 16 jointed teeth... 8

8-Peristome single (very rarely lacking), with teeth not united in pairs, but usually perforate or bifid, richly colored and rarely reflexed when dry. Plants often hoary with colorless leaf apices, nearly all

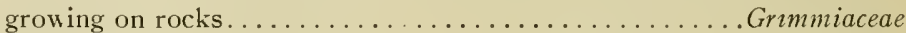

Peristome double (with one or two exceptions), teeth often united in pairs, rarely perforate, usually reflexed when dry, inner peristome of linear erect segments. Plants very rarely hoary, mostly tree-

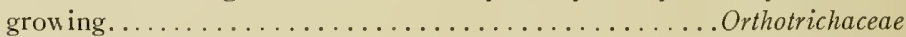

9-Peristome of four large distinct un;ointed teeth.......... Georgiaceae

Peristome having an inner plaited cone; outer peristome of shorter jointed teeth often present. Odd plants, best recognized by a

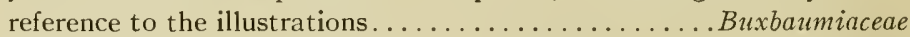

Peristome lacking, or of more than four teeth..............

10-Peristome of 32 to 64 non-articulate teeth; calyptra densely hairy with long whitish hairs (except Catharnea); leaves with numerous vertica: lamellae on the upper surface of the costa. Plants large and very often dark colored, growing on soil.........Polytrichaceae

Peristome when present consisting of I 6 to 32 plainly articulate teeth, frequently lacking. . . . . . . . . . . I

I I-Minute stemless plants with cleistocarpous capsules and usually persistent protonema............... Ephemereae of Funariaceae

Plants with stems, a few cleistocarpous or gymnostomous but mostly peristomate; protonema usually evanescent.............. I2

* Not listed. 
I2-Leaves papillose, at least above (except A ulacomnium); capsules strongly plicate or furrowed when dry; peristome double....... I3

Plants not possessing all three of these characters........... I4

13-Capsules nearly as broad as long, subglobose; inner peristome without cilia or with cilia little developed...........Bartramiaceae

Capsules longer than broad, subcylindric; cilia of inner peristome well

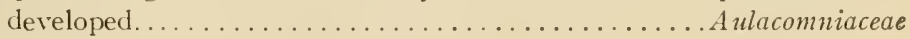

I4-Capsules cleistocarpous; leaves not papillose.

Archidiaceae ard Brucha in Dicranaceae

Capsules cleistocarpous; leaves papillose......Astomum in Tortulaceae

Capsules gymnostomous; leaf cells small, papillose.

Pottieae and Weiseae in Tortulaceae

Capsules gymnostomous, leaf cells large, smooth.

Physcomitrium in Funariaceae

Capsules peristomate.......................... I5

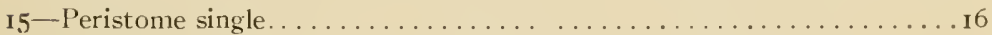

Peristome double...................... 8

I6-Capsules with a large swollen hypophysis, which is usually larger and more conspicuous than the spore-bearing part; leaves not papillose; growing on decaying animal matter....... Splachnaceae

Capsules without hypophysis (some with slender necks) ........ I7

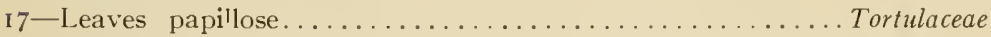

Leaves not papillose (except in Oncophoreae, one or two species of $D$. cranum, and slightly so in Ceratodon). See descriptions and il lustrations of these forms.................. Dicranaceae

I 8-Inner peristome of cilia only; plants with the habit of Polvtrichum.

Timmiaceae

Inner peristome of keeled segments, with intermediate cilia often present............................

I9-Segments opposite the teeth; capsules very strongly unsymmetric

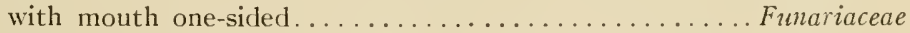

Segments alternate with the teeth; capsules less strongly unsyn-

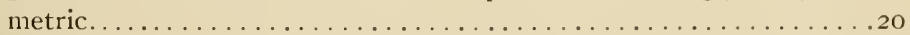

20-Capsules arcuate and unsymmetric, long-necked; inner peristome of sixteen rather narrow segments as long as the teeth or longer, without intermediate cilia; leaf cells small................eesiaceae

Capsules often pendent and symmetric, sometimes sligntly unsymmetric; inner peristome with well developed cilia (except in a few rare species) leaves often bordered by a margin of narrow elongated

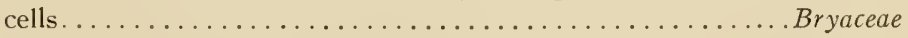

2I-Aquatic, long and floating, with leaves straight, or plants shorter with faicate-secund leaves; capsules immersed or emergent,

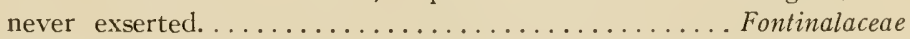

Terrestrial (or a few aquatic), seldom slender or floating, with capsules exserted on long setae....................... 22

22-Leaves papillose (except species of Mryurella, Leskea, and Thuidium); leaf cells short, rhomboidal or subcircular. ............ Leskeaceae 
Leaves not papillose, (slightly so in species of Leptodon, Cryphea, and Bryhnia)

23-Basal joints of peristome teeth marked with very fine transverse lines; segments of inner peristome well developed, keeled; cilia present (inner peristome without cilia and with narrow segments in many species with erect or suberect capsules. The transverse lines, even, are lacking in most of the species of the Climaceae and Entodonteae); leaf-cells elongated, sometimes rhomboidal but never rounded in the main portion of the leaf (except Porotrichum)

Hypnaceae

Basal joints of teeth without fine transverse lines; capsules symmetric, usually erect on straight setae; cilia of inner peristome lacking; segments usually narrowly linear, occasionally the inner peristome almost lacking. Practically all growing on the bark of

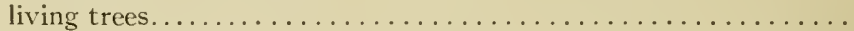

24-Leaf cells elongated as in the Hypnaceae; peristome teeth of ten united in pairs. Rare, mostly minute mosses..........Fabroniaceae

Leaf cells short and rounded; larger plants, many very common...25 25-Stems and branches flattened; leaves appearing two-ranked. Neckeraceae Stems and branches nearly terete; leaves not appearing two-ranked. 


\section{ORDER I. SPHAGNALES}

Famlit i. SPHAGNACEAE. The Peat Mosses

The Peat Mosses are so different from the other mosses that many bryologists do not consider them as mosses at all, but would put them in a separate class. Their protonema is much like the prothallium of a fern, and the stalk upon which the capsule is borne is not at all homologous with the seta of the other mosses, as it is an outgrowth from the gametophyte and not the lower portion of the sporophyte, i. e., it is developed from the moss plant instead of from the fertilized egg-cell. The capsules are globose with a well marked operculum but no peristome. The structure of the leaves is also very different from that of the other mosses. The cells of the branch leaves are of two sorts, very large hyaline rhomboidal or elliptical cells with the walls spirally thickened and often perforated by round pores, and the true chlorophyllose cells, which are narrow and elongated and lie between the others. While most forms are grayish green the leaves of some species are pink or deep red and furnish microscopic mounts of very great beauty.

Although the Sphagnaceae consist of but one genus, the number of species is very large and the distinctions are very puzzling. They all grow in bogs, swamps, moist mountain summits, etc.

Economically, the peat mosses are of more value than any others. In many portions of Ireland and Scotland peat is almost the only fuel supply of the peasantry. In the United States there is an abundant supply of peat. Dana estimates that there are $15,000,000,000$ cubic feet in Massachusetts alone. Peat has been taken out of the excavations for the N. Y. City subways.

\section{SPHAGNUM (Dill.) L.}

KEY

(Adapted from N. Am. Flora)

I-Cortical cells of the stem and branches reinforced by spiral fibril-bands 2 Cortical cells of the stem and branches without fibril-bands.......6 6 
2-Chlorophyll cells of the branch leaves entirely included, or exposed about equally on both surfaces.......................

Chlorophyll cells of the branch leaves usually triangular in section, with the base exposed on the inner surface of the leaf.........

3-Chlorophyll cells of the branch leaves exposed about equally on both surfaces, with a central lumen................papillosum

Chlorophyll cells of the branch leaves short-elliptic in section, central and usually entirely included................magellanicum

4-Chlorophyll cells of the branch leaves usually isosceles-triangular in

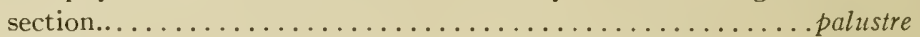

Chlorophyll cells of the branch leaves equilateral-triangular in sec-

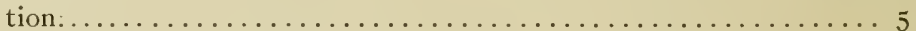

5-Cortical cells of the branches with their bases plane or nearly so.

imbricatum

Cortical cells of the branches each communicating by a saccate to funnelshaped extension with the next cell underneath.........portoricense

6-Cortical cells of the branches uniform, each with a pore at the upper

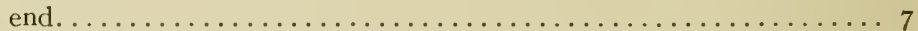

Cortical cells of the branches of two kinds, the larger retort cells with a neck and a pore in the axils of the leaves; or, if uniform, with-

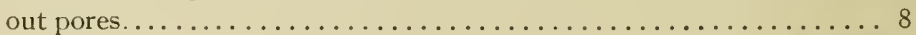

7-Chlorophyll cells of the branch leaves included............ compactum

Chlorophyll cells of the branch leaves exposed on the outer surface.

strictum

8 - Stem leaves with the membrane of the hyaline cells mostly resorbed on the outer surface, on the inner with membrane-gaps only in the

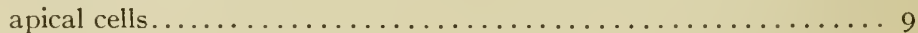

Stem leaves with the membrane of the hyaline cells usually not greatly resorbed on the outer surface, or if so, resorbed on both surfaces, producing a very lacerate leaf apex.............. Io

9-Plant large; branch leaves ovate-hastate, mostly squarrose.. squarrosum

Plant smaller; branch leaves ovate-lanceolate, usually imbricate..teres

Io-Chlorophyll cells of the branch leaves exposed exclusively or more broadly on the outer surface; or, if with central lumen and approximately equal exposure, the pigment brown............ I

Chlorophyll cells of the branch leaves exposed exclusively or more broadly on the inner surface; or, if with central lumen and approximately equal exposure, the pigment red........... 8

I I-Cortical cells of the stem small, thick-walled ............ I 2

Cortical cells of the stem larger, thin-walled, in $\mathbf{I}-3$ layers......... I3

I2-Chlorophyll cells of the branch leaves isosceles-triangular in section, the apex of the triangle reaching the inner surface of the leaf.recurvum

Chlorophyll cells of the branch leaves equilateral-triangular in section, the apex of the triangle not reaching the inner surface of the leaf....................................

13-Chlorophyll cells of the branch leaves broadly triangular in section, exposed only on the outer surface................ tenellum 
Chlorophyll cells of the branch leaves mostly exposed on both surfaces; if exposed only on the outer surface, narrowly triangular in

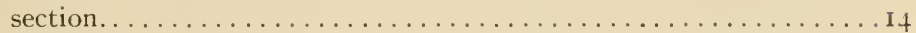

I4-Chlorophyll cells of the branch leaves triangular to rhomboidal in section, with broader exposure on the outer surface, the lumen

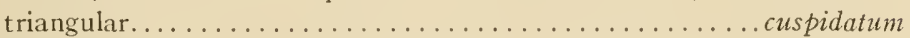

Chlorophyll cells of the branch leaves truncately elliptic or rectangular to trapezoidal in section, with equal exposure on both surfaces or slightly broader on the inner surface; or, if with broader exposure on the outer surface, the lumen lenticular and central or nearly so. . . . . . . . . . . . . . . . . . . . . . 5

I5-Hyaline cells of the branch leaves without fibrils ........ macrophyllum

Hyaline cells of the branch leaves fibrillose.............. 6

I6-Chlorophyll cells of the branch leaves exposed equally on both surfaces or more broadly on the outer one............ subsecundum

Chlorophyll cells of the branch leaves usually exposed a little more broadly on the inner surface................... 7

I7-Pores on the outer surface of the branch leaves if present, never more than 2 to each cell.............................

Pores on the outer surface of the branch or stem leaves always more than two to each cell.................cyclophyllum

I 8 - Stem leaves fimbriate-lacerate in the apical part . . . . . . . . . I9

Stem leaves not notably lacerate in the apical part ............

I9-Lacerate at both sides and apex................ fimbriatum

Lacerate only across the broad truncate apex.......... Girgensohnii

20-Hyaline cells of the branch leaves smaller, their free convexity on the outer surface mostly less than $1 / 2$ their diameter......... I

Hyaline cells of the branch leaves large in section, their free convexity on the outer surface usually more than half their diameter. .23

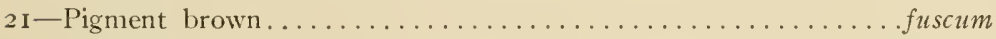

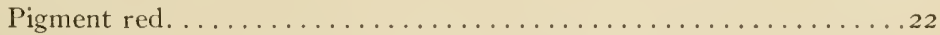

22-Outer surface of the branch leaves with very small round strongly ringed pores in the apical part................... Warnstorfii

Outer surface of the branch leaves with much larger elliptic pores.

capillaceum

23-Pigment brown, sometimes passing to purplish......... plumulosum

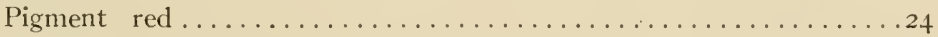

24 -Margin of the branch leaves entire...........................

Margin of the branch leaves denticulate..............tabulare

S. erythrocalyx Hampe is reported from New Jersey in N. Am. Flora. It is distinguishable from $S$. papillosum by not having papillae on the chlorophyll cells of the branch leaves.

S. quinquefarium (Lindb.) Warnst. should be found. It is distinguished from $S$. capillaceum by having its leaves mostly as broad as long instead of $\mathrm{I} 1 / 2$ or more times as long as broad. 
S. capillaceum (Weiss) Schrank. (S. acutifolium Ehrh.) Common.

Var. tenellum (Schimp.) A. L. Andrews. "Labrador to New Jersey," N. Am. Flora.

S. compactum DC. (S. rigidum Sch.) "Closter, N. J.," Musc. App. 8 (as var. humile). The same, No. 7 , is from Pine Barrens of N. J.; Beacon Falls, Ct., Nichols, Bx!

S. cuspidatum Ehrh. Frequent.

Var. Torreyi (Sull.) Braith. "Manchester Pond, Ocean Co.," Flora N. J.; New Haven, Bry. Ct.; Greenport, Latham.

S. cyclophyllum Sull. \& Lesq. "Stagnant pools and marshes on bog ore beds in Southern N. J.," Musc. App. 25; near Manchester, N. J., Aust., Bx!

S. fimbriatum Wils. "Swamps on the Palisades near Closter, N. J.," Musc. App. I9; swamp, S. Id., Clarke, Bx!

S. fuscum (Sch.) H. Klinggr. New Haven, Bry. Ct.

S. Girgensohnii Russow. In wet woods, Yonkers, E. C. Howe, Bx!; Closter, Austin, Bx!; Hampden, Bry. Ct.

S. imbricatum Hornsch. (S. Austinii Sull.). "Swamps near Farrango and Manchester, Ocean Co., N. J.," Musc. App. 2; New Haven, Bry. Ct.

Var. affine (R. \& C.) Warnst. Hempstead, L. Id., E. G. B., Bx! (as S. affine compactum); Orange, etc., Bry. Ct.

S. macrophyllum Bernh. Southampton, L.Id., Clute, Bx!; pines of N. J., Austin, Bx!; Fonds, Ocean, Cumberland, and Gloucester Co's., N. J., Rau, Bx!

S. magellanicum Brid. (S. medium Limpr.) New Haven, etc., Bry. Ct.

S. palustre L. (S. cymbifolium Ehrh.) Frequent.

S. papillosum Lindb. "Bogs near Batsto," Flora N. J.; N. J. Musc. App. Suppl. 45I ; East Haven, Bry. Ct.

S. plumulosum Roell. "Labrador to N. J.," N. Am. Flora; New Haven, etc., Bry. Ct. (as S. subnitens). 
Var. flavicomans (Card.) A. L. Andrews. "Southward along the coast to N. J.," N. Am. Flora; New Haren, Bry. Ct.

S. portoricense Hampe. "Ponds and pools of Southern N. J.," Musc. App. I. "Manchester Pond, Ocean Co.," Flora N. J.

S. pulchrum (Lindb.) Warnst. "Labrador to N. J.," N. Am. Flora.

S. Pylaesii Brid. Border of Pond, Manchester, Ocean Co., N. J., Austin, Bx!

S. recurvum Beauv. Orient, Latham; East Haven, etc., Bry. Ct.

S. squarrosum Crome. "Southward to N. J.," N. Am. Flora.

S. strictum Sull. "Swamps and bogs, Northern N. J.," Musc. App. 20. Fide label on this number in the N. Y. Bot. Gardens collection (issued as S. Girgensohnii).

S. subsecundum Nees. Common. A synonym of S. laricinum Spruce and of $S$. neglectum Angstr.

S. tabulare Sull. (S. molle Sull.) "Southern N. J. to Florida," Musc. App. 9; "Northport, Sanial," Flora L. Id.

S. tenellum Pers. (S. molluscum Bruch) "Peat bogs in water an inch or less in depth in Pine Barrens," Flora N.J.

S. tenerum Sull. \& Lesq. New Haren, Bry. Ct. [as S. tenerum (Aust.) Marnst.]

S. teres (Schimp.) Ångstr. "Low grounds, Closter and Southern N. J.," Musc. App. 2 I and Suppl. 452; "Budds Lake," Flora N. J.

S. Warnstorfii Russow. Hampden, etc., Bry. Ct.

\section{ORDER II. ANDREAEALES}

Characterized chiefly by the dehiscence of the capsule, which splits into four valves after the manner of the Hepaticae, the valves remaining coherent at the apex; also by the absence of any air cavity between the capsule walls and the spore sac. 


\section{FAMILY 2. ANDREAEACEAE.}

The only family of the order. Mosses of alpine or subalpine habitat, growing upon granitic or slaty rocks; with the habit and color of Grimmia. The appearance is always dark, sometimes black, and the leaves are very brittle and so dense that they need to be soaked in a solution of caustic potash for a few moments, in order to make their structure apparent under the microscope. The presence of chlorophyll in the leaves is not apparent except in very young leaves. Leaf cells small, very thick walled. There is very little difference in the sporophyte in the different species.

ANDREAEA Ehrh.

L.eaves without costa . petrophila Leaves costat Rothii

A. petrophila Ehrh. "Steep dry rocks and boulders near Closter, N. J.," Musc. App. 42. "On boulders near Sparta," Geol. Survey N. J. Summer.

A. Rothii W. \& M. (A. rupestris of many authors.) "Rocks by the Hudson River, Yonkers," Musc. App. 43 and E. C. Howe, Bx! Summer.

\section{ORDER III. BRYALES}

\section{Suborder I. Nematodonteae}

Peristome teeth solid, not transversely barred (very faintly so in Buxbaumia), derived from several concentric series of cells of the sporogonium.

\section{FAMILY 3. GEORGIACEAE}

All of our mosses belonging to this family are distinct in the four-parted peristome, each of the four teeth being composed of a solid mass of cellular tissue. The leaves are ovate or lanceolate, smooth, costate, leaf-cells rounded-hexagonal. 
GEORGIA Ehrh.

G. pellucida (L.) Rabenh. (Tetraphis pellucida Hedw.) Common in moist woods on humus, less frequently on rotten wood than farther north. Autumn-spring.

\section{FAMILY 4. POLY'TRICHACEAE}

Plants usually of a large size, the simple or slightly branched stems growing from a creeping underground stem (except Pogonatum brevicaule and $P$. brachyphyllum). Stems with a central woody strand, which is the nearest approach to a vascular bundle in the non-vascular cryptogams Leaves usually narrow, with the base sheathing or at least with the basal part of the leaf hyaline with larger cells. The costa bears on its upper surface, except at the hyaline base, longitudinal strips of tissue (lamellae) one cell thick and attached to the upper surface of the costa by one edge; the upper cell of the lamella is often of a different shape from the others, and seen in cross-section is of great value in determining species. The upper leaf cells are usually hexagonal. The plants are usually dioicous with the antheridia borne in conspicuous terminal rosettes. Capsule on a long smooth seta, large, cylindrical or prismatic, with $4^{-6}$ angles. Calyptra cucullate, covered with a dense felt of hairs, or at least roughened at apex with short spinose projections. Peristome of 32 or 64 teeth, short, without joints, triangular in cross-section. Columella expanded at the top into a circular membrane, the epiphragm, which is attached to the tips of the teeth, and helps control spore distribution.

Key to the GeNera

I-Capsules square or six-angled................ Polytrichum

Capsules cylindric.............................

2-Calyptra hairy; leaves not crisped when dry ........... Pogonatum

Calyptra not hairy; leaves crisped when dry ............. Catharinea

POLYTRICHUM Dill. The HAIR-CAP Mosses.

(Plate II, Fig. I.)

The leaves are large, not bordered, with a sheathing membranous base and very numerous straight lamellae occupying 
the greater part of the width of the leaf above the base; upper cell of the lamellae differentiated.*

Capsules prismatic, four-to six-angled, of ten nearly cubical. Peristome teeth generally sixty-four. Calyptra densely hairy.

\section{KEY}

I - Leaf margins serrate, not infolded $\ldots \ldots \ldots \ldots \ldots \ldots \ldots \ldots \ldots \ldots \ldots$

Leaf margins entire, thin and infolded.................... 3

2-Capsules cubical, beak short........................mmune

Capsules much longer than broad, beak long, neck tapering. Ohooense 3-Plants of dry situations, small ( $\mathrm{I} \mathrm{cm}$. to $2 \mathrm{~cm}$.), leaves with long white awns.............................. piliferum

Plants larger, leaves without white awns................. 4 4-Plants of lowlands without felted radicles; capsules $3 \mathrm{~mm}$. to $5 \mathrm{~mm}$.

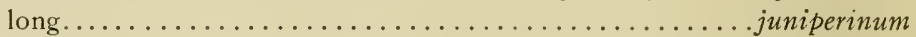

Plants of pine barrens or subalpine regions; stems covered with a dense felt of radicles, capsules $2 \mathrm{~mm}$. to $3 \mathrm{~mm}$. long....... strictum

Our species are readily divided into two groups, as shown in the key. One with serrate plane margins and the other with margins thin and infolded, not serrate except at the extreme apex. These species are all earth-growing.

P. commune L. Very common. A nuisance in old fields where it often crowds out the grass. According to Prof. J. F. Collins most of our material from Long Island and probably elsewhere is var. perigonale (Mx.) B. \& S. June-July.

P. Ohioense R. \& C. Common, more frequent in wooded places. June.

P. juniperinum Willd. Orient, Latham; Hempstead, Hulst (25288)!; High Bridge, Denslow; Huntington, L. Id., J. E. Rogers; Garretstons, S. Id., E. G. B.; Forked River, N. J., Lighthipe; Closter, N. J., Austin. All but the first two localities are represented at the Bronx.

P. piliferum Screb. Dry barren soil, frequent. June-July.

P. strictum Banks. "Pine barrens, common," Flora N. J.; Lakehurst, N. J., in and around bog!!; New Haven, Bry. Ct.

* In making cross-sections of the leaves to determine the nature of the terminal cells of the lamellae, the upper portion of the leaf should be used, as these cells are not characteristic near the base. 


\section{POGONATUM BeaUv.}

The Pogonatums differ from the Hair-caps mainly in the cylindrical capsules, not square or angular in section. The teeth are thirty-two and the capsules are straight or curved. The spores mature in autumn or winter, except in P. alpinum, in which they mature about July. Our species are small plants from persistent protonema.

Leaves lanceclate-subulate, serrate; capsules erect. ...

brevicaule Leaves lingulate, blunt, entire; capsules inclined when fresh. .brachyphyllum

P. brevicaule (Brid.) P. B. [P. tenue (Menz.) E. G. B.] Frequent on bare soil.

P. brachyphyllum (Mx.) P. B. Grassy hills, Orient, Latham!! "Sandy loam, Toms River, N. J.," Musc. App. 234.

\section{CATHARINEA Ehrh.}

Leaves not sheathing and but slightly embracing the stem, lingulate or ovate-oblong, crisped when dry, with a few $(I-\gamma)$ narrow lamellae; margins bordered, serrate, teeth often in pairs. Calyptra merely roughened with a few vestigial hairs. Capsule cylindric, of ten somewhat curved; operculum long rostrate; peristome of thirty-two teeth.

The sporophyte of the Catharineae is in good condition from late autumn to early spring.

\section{KEY}

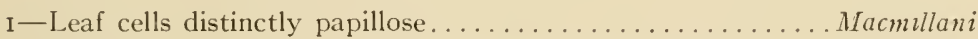

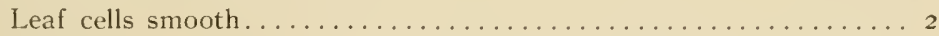

2-Capsule 4: I; leaves not at all wavy on the margins when moist,

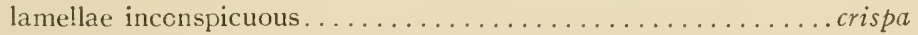

Capsule $6-8$ : I; leaf margins wavy when moist........... 3

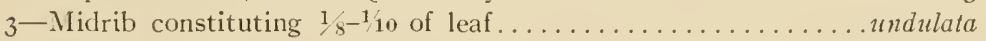

Midrib constituting $1 / 3-1 / 4$ of leaf $\ldots \ldots \ldots \ldots \ldots \ldots \ldots \ldots \ldots$ angustata

C. crispa James. Frequent in fresh water marshes and along moist banks of streams, especially along the south shore of L. Id.

C. angustata Brid. Very common on rather dry sandy soil, particularly if somewhat shaded. Mr. Geo. S. Bryan, of the Univ. of IVisconsin, has made studies showing that we have another species or that this is frequently monoicous. 
C. Macmillani Holzinger. "In dry exposed situations," New Haven and Orange, Bry. Ct.

C. undulata (L.) NW. \& M. Moist soil in woods. Infrequent except in N. J. Orient, Latham, Prospect Park, Jelliffe, Bx!; Rosedale, L. Id.!!; Banks of the Bronx River, Bronx Park, E. G. B. Bx!!; New Dorp, Princes Bay and Richmond, S. Id., E. G. B. Bx!

\section{FAMILY 5. BUXBAUMIACEAE}

Plants very small, almost or quite stemless; growing on earth or rotten wood; leaves few or none; perichaetial leaves present but often disappearing long before the maturity of the capsule. Capsule very large in proportion to the size of the plant, oblique and asymmetric. Calyptra small, conical. Peristome single or double.

A most peculiar and fantastic family, the members of which will be readily recognized by a comparison of the photographs given in $\mathrm{Pl}$. $\mathrm{I}$.

\section{KEY}

Leaves large and conspicuous

Webera

Leaves absent when sporophyte is mature...

Buxbaumia

\section{BUXBAUMIA Haller}

B. aphylla L. Closter, Flora N. J.; Five collections from Bronx Park by E. G. B. and R. S. W., Bx!; Yonkers, Mrs. Northrop, Bx!; Lawrence, L. Id., Brainerd, also Jamaica and Cold Spring!! Autumn to spring.

WEBERA Ehrh. (Diphyscium Mohr.)

W. sessilis (Schmid.) Lindb. Frequent!! July.

\section{Suborder II. Arthrodonteae}

Peristome teeth thin, derived from the cell-walls of a single layer of cells of the sporogonium, transversely barred, sometimes entirely lacking. 


\section{GROUP I. APLOLEPIDEAE}

Peristome single, composed of two layers of plates made by a deposit on the inner and outer side of the original cell-wall. In the outer layer a single undivided plate forms the entire width of the tooth, but the inner plate is divided by a median line into two parts. The teeth are of ten partially split along this median line as in Dicramum, or entirely cleft to the base as in Barbula. Ceratodon represents an intermediate condition. With the exception of some species of Fissidens, our Aplolepideae are acrocarpous.

\section{FAMILY 6. ARCHIDIACEAE}

Small terrestrial mosses, mostly perennial; $0.5-1.5 \mathrm{~cm}$. high; branching by innovations below apex. Central strand present. Leaves lanceolate, costate. Capsule apparently sessile, spherical, cleistocarpous, of a single layer of cells, producing about 16 very large polyhedral spores, the largest known in the mosses.

Except for the peculiarities of the capsule wall and spores this family is close to the cleistocarpous Dicranaceae. The capsules often appear lateral, either by successive innovations or by developing on a short branch. The only genus is

\section{ARCHIDIUM Brid.}

A. Ohioense Schimp. "Flat rocks, Palisades, Bergen Co., N. J.," Austin, Bx! Autumn to spring.

A. alternifolium (Dicks.) Schimp. "Old fields near N. Y. City," Austin, Bx! (As Phascum alternifolium.)

A. alternifolium is paroicous with leaf cells up to 27 by $\mathrm{I} 35 \mu$, while $A$. Ohioense is autoicous, leaf cells 13 by $54 \mu$.

\section{FAMILY 7. DICRANACEAE}

Plants varying in size from exceedingly minute to several inches in height, dichotomously branched. Leaves broadly lanceolate to subulate, often sheathing at base, costate, occasionally papillose; leaf cells quadrate or rectangular to linear, chlorophyllose above, more elongated and with little or no 
chlorophyll toward the base, often special inflated cells at the basal angles. Calyptra smooth, narrow, cucullate. Capsule on an elongated seta, narrow, oval to cylindrical, frequently cernuous; operculum usually long-beaked; peristome of I6 teeth which are cleft half-way to the base or further into two lanceolate or subulate divisions, usually of a reddish color, transversely barred, with fine vertical striae between the bars. There are a few cleistocarpous species with capsules rounded and immersed or elongated and exserted.

The leaf character and the peristome when present will usually indicate the family to one who is at all familiar with it, but in some genera it is closely related to the Tortulaceae [e. g., Ditrichum and Trichostomum; Barbula (Didymodon) and Ceratodon]. The plants of this family are inhabitants of soil and rocks, rarely growing on trees, frequently on decaying wood.

For convenience our genera may be grouped into eight tribes or subfamilies.

Key to Subfamilies of the Dicranaceae

I-Cleistocarpous; capsules spherical and immersed or pear-shaped and

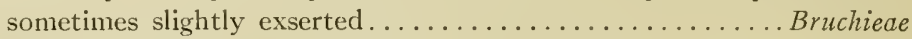

Capsules operculate and peristomes well developed ........... 2

2-Plants large (with few exceptions); leaves witl much enlarged and

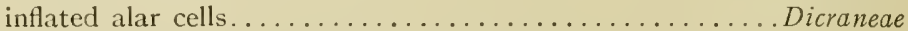

Plants smaller; leaves without enlarged and inflated angular cells... 3 3-Capsules with a long slender neck, sometimes longer than the urn

Trematodonteae

Capsules without a long neck................... 4-Rare minute plants of high altitudes or cool cliffs; teeth variable but not cleft to base................................

Peristome teeth cleft to the base into two filiform legs (except

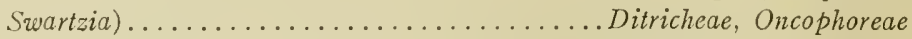

Peristome dicranoid; plants like small Dicrana in appearance.

Dicranelleae

Peristome various; upper leaf-cells minute, often papillose... Oncophoreae

\section{Subfamily BrucimeaE}

Small ( $8 \mathrm{~mm}$. or less) yellowish- or brownish-green mosses, growing upon soil in extensive tufts. Protonema often persistent. Leaf cells not papillose and mostly elongated-rectangular; alar cells not enlarged or inflated. Capsules cleistocarpous, subglobose and immersed, or pear-shaped and immersed to fully exserted. 
We have only two genera of this subfamily, Bruchia and Pleuridium. Bruchia has capsules with a conspicuously developed neck, so that the capsules are pear-shaped. Because of this long neck the genus is often put in the Trematodonteae, but it seems most convenient to follow Limpricht in this matter and certainly no violence is done to natural relationships.

\section{BRUCHIA Schwaegr.}

With the characters of the subfamily. Distinguished from Pleuridium (except P.palustre) by the pear-shaped capsules and mitrate calyptra; often growing with it, but distinguished easily by a hand-lens by the characters given. Our species catch the eye when growing with Pleuridium by reason of the partially exserted capsules.

Paroicous; capsule ovoid; stems up to I $\mathrm{cm}$. long; leaves nearly smooth.

flexuosa

Autoicous; capsule pyrif srm; st `ms up to $3 \mathrm{~mm}$. long; leaves subpapillos?.

Sullivantii

B. Sullivantii Aust. Lawrence and Woodhaven, L. Id.!!; West Farms, Sanial, Bx! May. Probably frequent in rather dry fields, of ten occurring with Pleuridium subulatum which matures its spores at least two weeks earlier.

B. flexuosa (Sw.) C. Muell. Mrs. Britton's garden and old fields, New Dorp, S. Id., E. G. B., Bx!; "Wet meadows about Closter and Camden, N. J.," Musc. App. 56.

\section{PLEURIDIUM}

Plants annual or perennial, in dense cushions; stems very short, simple or branching; upper leaves longer than the lower; more crowded, erect-spreading (except in P. Sullivantii) or secund, not crisped; costa excurrent or percurrent and forming most of the apex; capsules ovoid-globose, apiculate; calyptra cucullate (except in $P$. palustre). Growing in light sandy soil, of ten among grass. Spores in spring.

Besides Bruchia the other genera most likely to be confused with Pleuridium are: Archiaium, differentiated by having only about sixteen very large $(25 \mathrm{~mm}$.) smooth spores and capsule 
not apiculate; Phascum cuspidatum with a round smooth excurrent costa and upper leaf cells rounded hexagonal and papillose on the back; some other small species of the Tortulaceae which also have papillose cell walls, or have ovate or ovoid leaves with costa vanishing or slightly percurrent; Ephemerum, in which the plants are stemless, being scarcely more than buds on a persistent protonema.

\section{KEY (adapted from N. Am. Flora)}

I-Calyptra mitrate; stomata of the capsule wall median.......palustre

Calyptra cucullate; stomata of the capsule wall basal. .......... 2

2-Leaves erect-appressed, imbricate, ovate or mucronate..... Sullivantii

Leaves spreading or secund, lanceolate-subulate............ 3

3-Antheridial buds usually axillary to the lower leaves; perichaetial leaves abruptly subulate, the awn long and roughly serrate.

alternifolium

Antheridia in the perichaetium; perichaetial leaves tapering into the awn............................. 4

4-Perichaetial leaves entire at base, awn rough............. subulatum

Perichaetial leaves toothed at base, awn nearly smooth..... Ravenelii

P. subulatum (L.) Rabenh. Frequent on sandy banks and in old fields. April-June.

P. alternifolium (Kaulf.) Rabenh. New Dorp, S. Id., E. G. B., Bx!; Staten Id.!!; "Old fields, Closter, N. J.," Austin, Bx!; "Glen Cove, L. Id., Sanial," Flora, L. Id. May-June.

P. Ravenelii Aust. "On light sandy soil. New Jersey," Musc. App. Suppl. 457. March-June.

P. Sullivantii Aust. "Light sandy soil in fields. Spores in spring. Orange," Bry. Ct.

P. palustre Br. \& Sch. "Old fields, N. J., James," Musc. App. 55; Flushing, I. Id.!! Spring.

\section{Subfamily Ditricheaf}

Plants short or tall; leaves lanceolate-subulate without enlarged alar cells; capsule oval to cylindric, erect or nearly so; peristome of sixteen narrow teeth, which are often cleft to the base into thirty-two filiform cilia. 
I-Leaves glossy, not glaucous....................

Leaves glaucous, with a waxy bloom.......................... 2-Upper leaf cells more or less elongated; capsules usually erect and smooth but sometimes inclined and somewhat wrinkled...Ditrichum

Upper leaf cells roundish-quadrate, sometimes slightly papillose; capsules inclined and deeply furrowed when dry.......... Ceratodon

\section{DITRICHUM Timm.}

Plants tufted, slender, growing on soil or rocks; upper leafcells narrowly rectangular to quadrate; capsule on a slender straight seta, oval to cylindric, erect or slightly inclined, with an annulus; peristome erect, of sixteen long teeth, cleft into two filiform papillose divisions, which are sometimes more or less united.

I-Monoicous; seta yellow; costa long excurrent............pallidum

Dioicous; seta orange, red or brownish; costa short excurrent..... 2 2-Leaves secund. subulate; perichaetium not sheathing........ pusillum

Leaves erect appressed, lanceolate; perichaetium sheathing...... lineare

D. pusillum (Hedw.) Timm. [D. tortile (Schrad.) Hampe.] Very common on bare, rather moist soil. Autumn-spring.

D. lineare (Sw.) Lindb. [D. tortile vaginans (Sulliv.) Grout.] With the same habitat as the last but less common. Autumn. Immature sporophyte (in early August) is sometimes bright yellow.

D. pallidum (Schreb.) Hampe. Common in rather dry sandy places. June.

SAELANIA Lindb.

Leaves linear-lanceolate, serrate, costate to apex. Differing from Ditrichum chiefly in the granular or filamentous "bloom" on the dorsal surface of the leaves, and the minute quadrate to somewhat oblong leaf cells.

S. glaucescens (Hedw.) Broth. "Crevices of rocks, Little Falls, N. J., and Haverstraw, N. Y.," Musc. App. I2 I.

CERATODON Brid. (Plate II, Fig. 2.)

Plants short (sometimes reaching two or three inches in damp shaded places); in dense cushions matted together with radi- 
cles. Leaves small, ovate-lanceolate, acuminate or subulate; cells roundish to quadrate, sometimes slightly papillose dorsally, somewhat elongated at the base. Capsule usually inclined and deeply furrowed when dry. Peristome from a narrow basal membrane, of 16 teeth, bifid nearly to the base.

C. purpureus (L.) Brid., our only species, is one of the commonest of all our mosses. It is found on the edges of paths, roofs of old buildings, sand by the seashore, and in general any barren compact soil is its favorite habitat.

Var. aristatus Aust. "Plants taller, often paler; seta yellow"; leaves acute or acuminate, costa excurrent; xerophytic." "Sandy barrens of N. J.," Musc. App. I I 7 .

\section{Subfamily Seligerieae}

Plants minute, scarcely branched; leaves narrowly lanceolatesubulate, without distinct alar cells; capsule exserted, erect or nearly so. Peristome of 16 short teeth, cleft or perforate or nearly entire (lacking in S. Doniana).

\section{SELIGERIA B. \& S.}

S. Doniana (Smith) C. Muell. "In pockets and hollows of rocks, rare; Sparta \& Ogdensburg,. New Jersey;" Austin, Bx! Summer.

S. setacea (Wulf.) Lindb. [S. recurvata (Hedw.) B. \& S.] "On moist shaded rocks at Hohokus and Godwinville, N. J.," Musc. App. I Io. Spring-summer.

\section{Subfamily Oncophoreae}

Leares chlorophyllose, opaque, usually papillose, without distinct angular cells, the upper minute, quadrate. Capsule on a long seta, oblong or subcylindric, usually unsymmetric and inclined, usually striate and frequently strumose. The distinguishing characteristic of this subfamily is the small and rounded or quadrate of ten papillose cells of the upper leaf, and this character indicates a very close relationship to the Tortulaceae, which is also shown in the peristomes of Saelania and Ceratodon. 


\section{Key to GenerA}

I-Leaves not papillose; capsule inclined and strumose, peristome

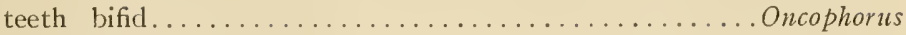

Leaves smooth or slightly papillose; capsule erect, teeth not bifid.

Rhabdoweisia

Leaves papillose.

2-Capsule erect and symmetric; peristome teeth mostly undivided.

Oreoweisia

Capsule from nearly erect to unsymmetric and nodding. peristome teeth divided about half way................ Dichodontium

\section{RHABDOWEISIA B. \& S.}

Small mosses growing in dense tufts or cushions, often in damp shaded crevices of rocks and overhanging ledges. Leaves lanceolate to linear, more or less crispate, smooth or mamillose rather than papillose. Capsule erect and symmetric, 8-furrowed when dry; peristome teeth narrowly lanceolate, without median line.

R. denticulata (Brid.) B. \& S. "On rocks in ravines, Pascack, N. J., and Rockland Co., N. Y.," Musc. App. 72; Redding, Ct., Bx! Summer.

\section{OREOWEISIA De Not.}

Small compactly tuftel rock-growing mosses. Leaves ovatelanceolate to linear-lanceolate, somewhat crisped; lower leaf cells rectangular, smooth; the upper papillose (mamillose) on both sides, square to roundish. Capsule erect, not furrowed; teeth lanceolate, entire or divided.

O. serrulata (Funck.) DeNot. "On perpendicular face of moist rocks, Palisades N. J., and Haverstraw, N. Y.," Musc. App. 7o. Sterile in our range.

\section{DICHODONTIUM Schimp.}

Plants cespitose or in loose mats. Leaves lingulate to linearlanceolate, widely spreading when wet, incurved to crispate when dry; lower leaf cells elongate, upper roundish to quadrate, more or less papillose both sides. Capsule cylindric to oblong, erect and symmetric to cernuous and curved; peristome teeth united below, more or less divided. 
D. pellucidum (L.) Schimp. "On rocks subject to inundation in deep glens near West Vernon, Sussex Co., N. J.," Musc. App. 76; New Haven, Bry. Ct. Autumn to spring.

\section{ONOCOPHORUS Brid.}

Mosses of damp ledges, earth, and decaying wood, mostly moderate in size with leaves long, slender and crispate when dry,

O. Wahlenbergii Brid. Yonkers, E. C. Howe, Bx!

\section{Subfamily Trematodonteae}

Plants small, caespitose. Leaves lanceolate-subulate, without distinct angular rells. Capsules with a long slightly inflated neck, which is sometimes longer than the capsule itself. Capsule cernuous; peristome of 16 teeth which are perforate or cleft.

\section{TREMATODON Mx.}

Neck about the length of the $u r n \ldots \ldots \ldots \ldots \ldots \ldots \ldots$ ambiguus Neck about twice the length of the urn.........................

T. ambiguus (Hedw.) Hornsch. Jamaica!! Summer.

T. longicollis Mx. "Low grounds, Closter, N. J.," Musc. App., 476; Toms River, N. J., Bx!

\section{Subfamily Dicranelleae}

Plants small, like miniature Dicrana, scarcely branched. Leaves smooth, lanceolate-subulate, without specialized angular cells. Capsule short, erect or inclined, frequently striate; lid beaked; peristome dicranoid, of I6 teeth, cleft to the middle into two filiform divisions.

\section{DICRANELLA Schimp.}

Small mosses resembling Dicranum in miniature, but without the enlarged angular cells. The general characters of the genus are those of the subfamily to which it belongs. The small size and narrow silky leaves, narrowed gradually or abruptly from a broader base to a channeled subulate apex, render the genus easy of recognition, especially if the dicranoid capsule be pres- 
ent. The capsules present variations similar to those of Dicranum, but capsules that remain erect and symnetric when dry and empty are rare. Our species are all dioicous.

\section{KEY}

I-Seta yellowish, sometimes becoming dark with age.......... 2

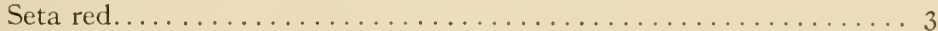

2-Capsule oblong, tapering at the neck, sulcate, mouth incurved

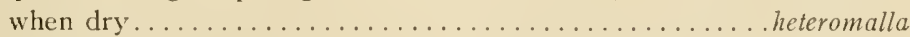

Capsule oblong, tapering at the neck, scarcely plicate, mouth erect when $\operatorname{dry} \ldots \ldots \ldots \ldots \ldots \ldots \ldots \ldots \ldots \ldots \ldots$ heteromalla orthocarpa

Capsule gibbous, strumose at neck, smooth when dry.......cerviculata

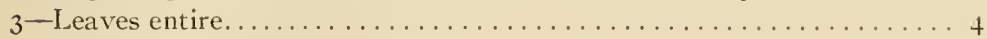

Leaves serrate or denticulate................... 5

4-Leaves secund; capsule striate when dry; operculum nearly as long as urn; annulus present..............................

Leaves scarcely secund; capsule smooth when dry; operculum $1 / 2$

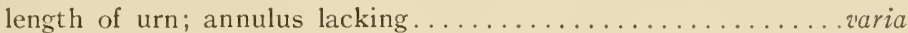
5-Leaves subsquarrose, from a sheathing hase. Schreberi

Leaves secund or erect, pellucid by reason of very large thin-walled cells.......................

D. heteromalla (L.) Schimp. Frequent on shaded, sandy banks. Autumn-winter.

Var. orthocarpa (Hedw.) E. G. B. [Var. Fitzgeraldi (R. \& C.) Grout.] The most common and abundant moss of the region. Sandy shaded places. Autumn. Hedwig's Dicranum orthocarpum was from Lancaster, Pa. Since learning this fact I have changed my opinion as to the name of this form. True $D$. heteromalla with the characteristic curved and wrinkled dry capsule is not very common wherever I have explored in this vicinity.

D. cerviculata (Hedw.) Schimp. "To N. J. and N. Y.," N. Am. Filora. "Peat bog, Hoboken, N. J., Torrey," Musc. Allegh. 167 and Musc. Bor. Am. 49 (Fide E. G. B.). Summer."

D. rufescens (Dicks.) Schimp. "Along shaded lanks along roadsides throughout northern N.J. and southern N. Y.," Musc. App. 74; Bronx Park, E. G. B., Bx!!; clay pits at Kreischersville, and near mausoleum in Moravian Cemetery, S. Id., F. G. B., Bx!; Glen Cove, L. Id.!! Summer.

D. varia (Hedw.) Schimp. "On nioist banks, rare in Bergen Co., N. J.," Musc. App. 78; Mendham, N. J., Austin, Bx!!; 
"Northport, Sanial," Flora L. Id.; S. Id., E. G. B., Bx! Autumnwinter.

D. Schreberi (Schrad.) Schimp. "Wet rocks and banks, Hohokus, N. J.," Musc. App. 77. According to N. Am. Flora Austin's specimens are var. robusta Schimp.

\section{Subfamily Dicraneae}

Common plants, large and often somewhat branched; some of the rarer species are small. Leaves narrowly lanceolate, of ten falcate-secund; cells at the angles enlarged, often inflated, hyaline or colored. Operculum usually long..beaked.

\section{DICRANUM Hedw. (Plate III, Fig. r.)}

Leaves smooth (papillose in spurium, montanum and occasionally in pallidum); lower cells rectangular, angular conspicuously dilated. Capsules on a straight erect seta, erect or inclined; teeth red, cleft half-way into two or occasionally three segments, vertically striate below with fine lines.

The Dicrana of our region are one of the most common and beautiful elements in woodland scenery. They are, for the most part, bright yellow-green and grow in wide thick tufts or mats. The leaves are frequently more or less secund. They are common on the ground, stones, rotten wood, and sometimes they occur on the base and trunks of trees. Most Dicrana mature their spores in autumn, but more observations are needed to give exact dates for each species.

KEY

I-Capsule cernuous, more or less arcuate............... 2

Capsule erect, symmetric............................. 9

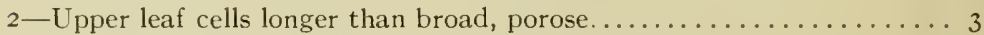

Upper leaf cells not porose, nearly as broad as long.......... 5

3-Capsules clustered, leaves strongly transversely undulate, silky.

undulatum

Capsules solitary ............................

4-Leaves transversely undulate when moist, slightly or not at all secund, costa often without lamellae at back; plants dull or pale

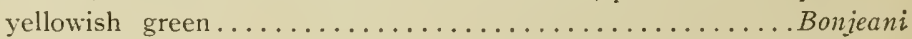

Leaves not at all undulate, secund, with strongly serrate lamellae

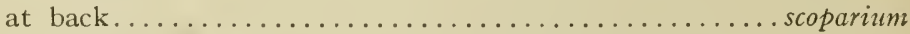

5-Leaves strongly papillose at back, little or not at all secund....spurium

Leaves not noticeably papillose (sometimes papillose in pallidum)... 6 


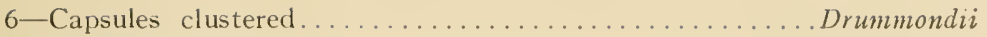

Capsules solitary . . . . . . . . . . . . . . . . . . . . 7

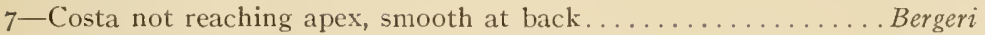

Costa percurrent or excurrent, roughened.............. 8

8 -Leaves strongly falcate secund and crispate, upper leaf cells regular.

Leaves little or not at all secund, upper leaf cells very irregular.

fuscescens

pallidum

9-Costa ending in the serrulate apex; leaves crisped when dry....... Io

Costa excurrent; leaves scarcely altered by drying............ I I

Io-Apex of leaf papillose at back; upper leaf-cells rectangular...montanum

Apex of leaf not papillose; upper leaf-cells less regular; plants commonly giving off numerous axillary erect flagella bearing minute

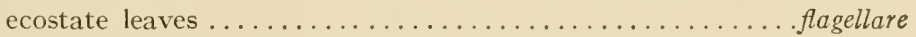

I I-Costa equaling $1 / 3$ width of leaf at the base, or less; leaves gradually narrowed to apex; all upper surface leaf-cells rectangular..... fulvum

Costa $1 / 2$ width of base of leaf, or more; leaves abruptly narrowed to a long slender point; all upper leaf-cells greatly elongated-linear.

longifolium

D. Bergeri Bland. Yonkers, E. C. Howe, Bx!; Bedford, Westchester Co., F. C. B. Bx!; "Swamps and wet woods, common in N. J.," Musc. App. 93.

D. Bonjeani DeNot. Swampy woods on New Jersey Palisades opposite Yonkers!!; Englewood, N. J., P. C. Clarke. Late summer or autumn.

D. Drummondii Muell. Orient, Latham!!; Fairfield, Ct., Nichols, Bx!; "Shaded pine woods." T. P. James. Geol. Surv. N. J. Summer.

D. flagellare Hedw. Very common on banks of streams and on hummocks in swampy woods. Summer. More variable than is indicated in most descriptions. An extreme form is

Var. minutissimum Grout, on dry peaty banks and stems of bushes forming a sort of close dense "fur." Leaves short, ovatelanceolate, broad pointed.

D. fulvum Hook. [including D. viride (S. \& L.) Lindb.]. Flushing, Brainerd (H. S.); Orient, Latham!!; Oyster Bay!!; Yonkers!!; Rocks, Closter, N. J., Austin, Bx!; Bedford and Bronx Park, Bx! L'sually growing on rocks in damp shaded places. Late summer and autumn. 
D. fuscescens Turn. This species which is abundant in mountainous regions has not yet been reported nearer than the Catskills.

D. longifolium Ehrh. "On shaded rocks and trunks of trees, Northern N. J.," Musc. App. 84. Summer.

D. montanum Hedw. Northport, Glen Cove and Oyster Bay, L. Id.; Harerstraw, Bronx Park and Eastchester; Palisades, Hoboken and Weehauken, N. J. On stones and decaying wood. Summer.

D. pallidum B. \& S. On soil in dry sandy places. Cedar woods, Orient, Latham; Tottenville, S. Id., E. G. B.; Lakewood and other Pine Barrens localities, Best, Small and Austin. Spring.

D. scoparium (L.) Hedw. Very common on the ground, stones, etc. in woods, and exceedingly variable. Late summer or autumn. Grades into D. Bonjeani.

D. spurium Hedw. Huntington, L. Id., J. E. Rogers, Bx!; "Rocks on Mts., New Jersey," Musc. App. 95; Pine barrens, I.akehurst and Toms River, N. J.!! Spring.

D. undulatum Ehrh. Wading River, L. Id., E. S. Miller, Bx!; "On rocks and the ground near Baumpies Hook, N. J.," Musc. App. 97, and "swamps about Closter," Musc. App. 98 (as D. robustum); Montague, N. J., Nash., Bx!

\section{FAMILY 8. LEUCOBRYACEAE}

Sporophyte as in Dicranaceae. Plants greenish white. Leaves broadly lanceolate to linear, consisting chiefly of a very broad costa which consists of three or more layers of two different kinds of cells.

\section{LEUCOBRYUM Hampe.}

Plants up to $5 \mathrm{~cm}$. or even $10 \mathrm{~cm}$. high; stem leaves $4-11 \mathrm{~mm}$. long, often secund; capsule usually distinctly strumose.......... glaucum

Plants up to $3 \mathrm{~cm}$. high; leaves $2-4.5 \mathrm{~mm}$. long, never secund, stiff and rigid; capsules scarcely strumose as a rule............. albidum 
L. glaucum (L.) Schimp. Common, forming dense rounded cushions.

L. albidum (Brid.) Lindb. The only specimen from our range that I can locate is in the herbarium of the $\mathrm{N}$. Y. Bot. Gardens from Herb. J. Cardot, Leg. H. A. Green. The species is distinctly a southern form and H. A. Green collected mostly in the Southern States. I suspect that N. C. and N. J. got confused in Herb. J. Cardot. It is reported from various localities in N. J. in the Geol. Survey but I doubt the authenticity of the material.

\section{FAMILY 9. FISSIDENTACEAE}

One of the most natural and easily recognized families. It can be easily recognized even when sterile by the distichous leaves, vertically placed and arranged in one plane, apparently split along the basal portion of the upper edge and clasping the stem and the lower edge of the leaf next above. The leaf-cells are small, rounded or hexagonal. The sporophyte is lateral or terminal, exserted; peristome like that of Dicranum, with sixteen forked, highly colored teeth, which are of ten papillose above.

\section{FISSIDENS Hedw.}

Two of our species, F. Julianus and $F$. Hallianus, are aquatic or subaquatic; the others are terrestrial, growing with erect stems on damp soil and stones. All have strongly costate leaves. The sheathing base of the leaf is called the vaginant lamina; the terminal lamella above the costa, the vertical lamina; and the dorsal lamella, the inferior lamina. The leaves are often bordered, sometimes with a number of elongated cells, much as in Mnium, but, more frequently, with cells of the same shape and size but of a different color.

\section{KEY}

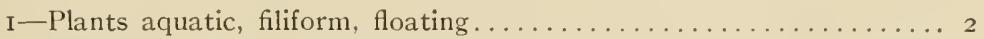

Plants terrestrial or submerged, not floating............ 3

2-Plants large, 2 to 6 inches long, much branched, habit of Fontinalis.

Plants small, not exceeding $1 \frac{1}{2}$ inches, little branched...... Hallianus 
3-Leaves (at least the vaginant lamina) bcrdered by a narrow band of elongated cclls........................... 4

Leaves bordered by several rows of paler, often incrassate cells of about the same size and shape as the others........... 5

Leaves not bordered (occasionally the outermost row of cells is a

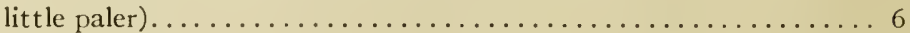

4-Border usually confluent at apex with the percurrent costa; anther-

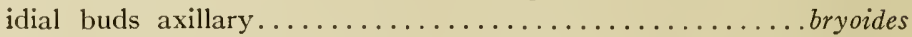

Border at apex narrow or wanting; antheridial buds at base of stem.

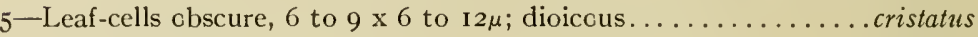

Leaf-cells distinct, 12 to $15 \times$ I 8 to $24 \mu$; monoiccus........ adiantoides

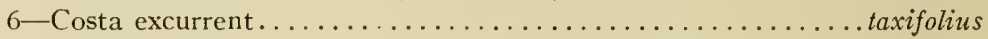

Costa ending in the apex or below...................... 7

7-Leaves entire, plants minute, scarcely $2 \mathrm{~mm}$. high in fruit......closteri

Leaves entire, plants in fruit averaging about $\mathrm{I} \mathrm{cm}$. high.... obtusifolius

Leaves serrulate............................ 8

8 -Costa nearly percurrent; leaf-cells 9 to $\mathrm{I} 8 \times$ I 2 to $24 \mu \ldots$ osmundioides

Costa ending some distance below apex; leaf-cells roundish, 8 to i $\mu$.

subbasilaris

F. adiantoides (L.) Hedw. Bronx Park, E. G. B., Bx!; Eastchester, S. H. Burnham; Yonkers, E. C. Howe; Closter, Austin, $\mathrm{Bx}$ ! "On wet rocks and' banks, very common," Musc. App. I06. Winter.

F. bryoides (L.) Hedw. Banks of the Hackensack R., Palisades of N. J. and Haverstraw, N. Y., Austin, Bx! Autumn.

Var. inconstans (Schimp.) Ruthe. Palisades, Austin, Bx! (Fide E. G. B.)

F. closteri Aust. "On rocks along rivulets, Palisades near Closter, N. J.," Musc. App. Suppl. 479.

F. cristatus Wils. Dolomite boulder near river, Bronx Park, E. G. B., Bx!; Plainfield, N. J. Weigmann.

F. Hallianus (Sull. \& Lesq.) Mitt. "On shaded rocks moistened by spray." Rau, Geol. Sur. of N. J., "Rocky rivulet, Sparta, N. J.," Io8b., Musc. App.

F. incurvus Schwaegr. Closter, Austin, Bx!; Brooks, Palisades, Gilman, Bx! Late autumn.

Var. minutulus Aust. "On stones in damp shady or springy places, very conmmon," Musc. App. 102; Annadale, 
Todt Hill, Richmond Valley, S. Id., E. G. B., Bx!; Bronx Park, E. G. B., Bx!

F. Julianus (Savi.) Schimp. "Rocky streams, N. J.," Musc. App. I08; spring between Demarest and Cresskill, N. J., Austin, $\mathrm{Bx}$ !; Kingsbridge!!

F. obtusifolius Wils. On rocks in rivulet, Overlook Park, Princes Bay, S. Id.!!

F. osmundioides (Sw.) Hedw. "On tussock, in springy places in swamps. Common about Closter," Musc. App. 104; Yonkers, E. C. Howe, Bx!; College Point, Brainerd! (H. S.); and Jamaica!! L. Id. Summer.

F. subbasilaris Hedw. "On roots of trees in woods, Closter," Musc. App. 105. Winter.

F. taxifolius (L.) Hedw. Common on shaded soil. Autumn to winter.

\section{FAMILY io. GRIMMIACEAE}

Plants growing upon rocks, rarely on soil (at least in our species), blackish-green when dry, almost black below. 'The young freshly moistened tips of the stems and branches are the only portions that are chlorophyll green. The plants grow in thin mats or more frequently in dense tufts or cushions. The stems of fruiting plants commonly branch by innovations below the apex. The leaves are often hyaline tipped, giving the plants a hoary appearance, but the hyaline tip consists of the whole apex of the leaf; usually lanceolate to ovate-lanceolate, with small thick-walled cells, often in several layers in the upper portion of the leaf. In Rhacomitrium the lower leaf-cells are longer, being usually linear, with strongly sinuose walls. The costa is present and is well developed in all the species except Hedwigia. The capsules are usually symmetric, ovoid to cylindric, frequently immersed or emergent. The seta is short even in species with exserted capsules, sometimes arcuate, though rarely so in our species. Calyptra mitriform or cucullate, sometimes papillose, smooth or plicate. Peristome single, 
often papillose, entirely lacking in Hedwigia; teeth entire, cribose or cleft, of ten resembling those of Dicranum, but entirely lacking the vertical striae characteristic of that genus.

The Orthotrichaceae are usually included in this family, but I entirely agree with Mr. Dixon that the differences in peristome are fully sufficient to warrant the separation into two families. Andreaea is the only genus likely to be misplaced in this family, and when sterile one might easily have difficulty in distinguishing it from the Grimmiaceae, but the plants are black even at the top and much more slender than the great majority of the Grimmiaceae.

Key to the Genera

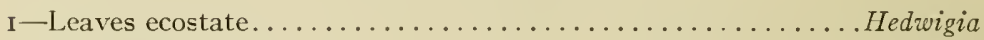

Leaves costate. ................................ 2

$2-$ Leaves crispate as in Ulota ........................... 4

Leaves not crispate............................ 3

3-Basal leaf cells linear, with incrassate sinuose walls; capsules all

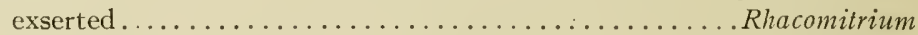

Basal leaf cells but little longer than broad, walls not sinuose... .Grimmia

Basal leaf cells but little longer than broad, upper basal somewhat sinuose; capsules immersed or emergent, not exserted.

Grimmia Pennsylanica and forms of G. apocarpa 4-Seta straight; upper leaves linear-lanceolate...........Ptychomitrium

Seta arcuate (or sinuose when dry); upper leaves long-linear from a short oblong base....................... Campylostelium

\section{HEDWIGIA Ehrh.}

Lower part of the plants brown or black, the upper green, with a tinge of gray due to the colorless tips of the leaves; capsules entirely concealed in the longer, more slender perichaetial leaves, the only indication of their presence being a slight enlargement of the ends of some of the branches. The capsules are almost spherical, with a clear-cut lid and no peristome; they mature in spring.

This genus is easily distinguished from all our other Grimmiaceae and from the Orthotrichaceae by its ecostate leaves; its large size, hyaline leaf apices and ciliate perichaetial leaves prevent any confusion with the ecostate species of Andreaea. By recent authors Hedwigia is put with the pleurocarpous mosses, where it probably belongs. 
H. albicans (Web.) Lindb. (II. ciliata Fhrh.) On rocks, frequent. Spring.

CAMPYLOSTELIUM B. \& S.

Plants minute, gregarious, on rocks. Leaves crisped when dry, linear-lanceolate; leaf cells above small, round, thickwalled. Calyptra nitrate; seta arcuate; capsule symmetric.

C. saxicola (Web., Mohr.) B. \& S. "On sandstone boulders near Closter, N. J.," Musc. App. rog. WVinter-spring.

\section{PTYCHOMITRIUM B. \& S.}

Distinguished from Grimmia by the plicate calyptra and crispate leaves.

P. incurvum (Schwaegr.) Sulliv. New Dorp, S. Id., and Bronx Park, E. G. B. (Bx.)!; “Old stone fences, Northern N. J. and Southern N. Y.," Musc. App. I53; Yonkers, Bx!

\section{GRIMMIA Ehrh. (Plate III, Fig. 2.)}

Plants dark green to almost black, short-stemmed, growing (in our species) almost exclusively on rocks, in more or less compact cushions. Leaves crowded, more or less appressed and somewhat contorted when dry, but not crispate, spreading to squarrose when moist, lanceolate in general outline, margins usually recurved and entire, except at the apex, which is of ten hyaline, but is composed of the upper lamina instead of the costa alone, giving the plants a hoary appearance in many species; costa well developed; leaf cells short and rounded above, almost opaque in most species, sometimes papillose; the lower cells elongated, of ten rectangular and nearly hyaline. Calyptra smooth; capsule ovoid to oblong, symmetric; immersed or exserted; peristome single, of 16 teeth which are entire, perforate, or even cleft in some species.

The genus is usually easily recognizable, but the species are difficult and are of ten almost impossible to determine in sterile specimens, as some of the critical leaf characters are variable. The position of the margin (recurved or plane) seems to be a fairly constant and useful character. Mature leaves from the 
middle and upper portions of stems must be chosen for examination. The hyaline apex is often confined to the mature upper leaves.

\section{KEY}

I-Leaves, at least the upper, ending in a whitish hyaline hair point.... 2

Leaves not as above............................ 5

2-Capsule longer than the seta, immersed; or if shorter than the seta the upper basal leaf cells are sinuose................... 3

Capsule shorter than the seta, emergent or exserted; no leaf cells sinuose...................................6 6

3-Upper leaves with long hair points; leaf cells not sinuose; capsule oblong ..................................mbigua

Upper leaves with long hair points; leaf cells somewhat sinuose.

Pennsylvanica

Upper leaves oft $n$ with short hair points............... 4 4-Lower leaf cells sinuose, but sherter than in Rhacomitrium. Pennsylvanica

Lower leaf cells not sinuose (sometimes slightly so in apocarpa)..... 5 5-Plants small and slender, in dense cushions, soft dull green; peristome teeth strongly cribrose; central strand present in stem. . conferta

Plants larger, loosely tufted; central strand lacking; peristome less cribrose................................ apocarpa 6-Leaf margins erect, of one layer of cells; seta curved ......... Olneyi

Leaf margins slightly recurved on one side at least, of one layer of cells; seta straight.......................... leucophea

G. apocarpa (L.) Hedw. "Common on rocks in moist ravines," Musc. App. I34. Frequent on S. Id. but much of the plant is possibly var. rivularis. Bronx R. near bridge, E. G. B., $\mathrm{Bx}$ ! No specimens known from L. Id.

Var. gracilis (Schleich.) W. \& M. "Shaded rocks, Palisades and Greenwood Mts.," Musc. App. I35; Bloodroot Valley, S. Id., E. G. B., Bx! Autumn-winter.

G. ambigua Sull. "Rocks on High Ton, Haverstraw, N. Y.," Musc. App. I42.

G. conferta Funck. "On rocks on the ground, Passaic Falls, N. J.," Musc. App. I38. Varieties on limestone rocks near Sparta and in Southern N. J., Musc. App. I39 \& I40. "On trap rocks near Haverstraw, N. Y.," Musc. App. I4I.

G. leucophea Grev. "Exposed rocks, Palisades," Musc. App. I46. Spring. 
G. Olneyi Sulliv. "On exposed rocks, Palisades and Northern N. J. and Southern N. Y.," Musc. App. I44. April.

G. Pennsylvanica Schwaegr. "On dry rocks, common," Musc. App. I 43; Northport and Gowanus, L. Id.; Van Cortland Park, N. Y. Bot. Gardens, Tuckahoe, Eastchester; Closter, N. J. Autumn-winter.

\section{RHACOMITRIUM Brid.}

Plants with much the habit and appearance of Grimmia, but usually larger, and in many species bearing numerous short lateral branchlets, giving the plants a peculiar modose appearance. The leaves are hyaline pointed in most of our species and the lower leaf cells, at least, are much elongated with thickened simuose-nodose cell walls, which character is the principal distinction from Grimmia: the leaf margins are recurved in almost all cases.

I-Some or all of the leaves with a hyaline point at apex......... 2

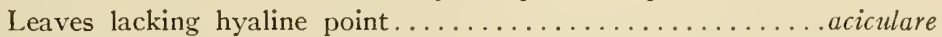
2-Plants with many short lateral branchlets; upper leaf cells at least 3 times as long as broad, sinuose..................microcarpum Short lateral branchlets lacking; upper leaf cells round-quadrate.

sudeticum

R. aciculare (L.) Brid. "Rocky beds of streams, Palisades, N. J.," Musc. App. I47; Bath, L. Id., Brainerd (H.S.)! Spring.

R. microcarpum (Schrad.) Brid. "Exposed rocks in the Ramapo Mts. of N. Y. \& N. J., rare," Musc. App. I49; Closter, Austin, Bx!; Musc. App. I48 issued as R. sudeticum from Suffern, N. Y. \& northern N. J. is in my set this species. Yonkers, E. C. Howe, Bx!

R. sudeticum (Funck) B. \& S. Probably the only data for this species from our range is from Musc. App. I48 as noted above. Some of this number may possibly be this species.

\section{FAMILY II. TORTULACEAE}

With few exceptions short-stemmed mosses, radiculose at base only, often caespitose, growing mainly on soil. Leaves of various shapes, margin usually entire and of only one layer 
of cells, costa strong; basal cells usually thin-walled, hyaline and rectangular; upper cells usually thick-walled, quadrate to subcircular, papillose. Seta straight; calyptra cucullate, smooth, capsule erect and symmetric or nearly so; cleistocarpous, gymnostomous, or, usually, peristomate; peristome when present of I6 straight or spirally twisted teeth which are often divided into two filiform papillose divisions, appearing as if there were 32 teeth.

\section{KEy to THE Genera}

I-Leaves widest at or near base, usually tapering to an acute apex.. 4

Leaves increasing in width from the base upwards, usually broad in outline and rounded at the apex except for the excurrent costa (some forms of Barbula unguiculata may be sought here)....... 2

2-Peristome lacking (in our species) .................... 2

Peristome present (very short in some species of Desmatodon)...... 3

3 - Costa strongly excurrent into a hair point; peristome of 32 filiform teeth from a high basal membrane, twisted to the left....... Tortula

Costa not excurrent (except in D. plinthobius); peristome teeth I6.

Desmatodon

4-Plants minute; cleistocarpous....................... 5

Plants larger; capsule opening by a lid; peristome lacking or present. . 6

5-Areolation dense and strongly papillose above; upper leaf margin strongly involute.......................... Astomum

Leaves more loosely areolate, margin slightly revolute above..Phascum 6-Peristome lacking; leaf margins plane or revolute........ Gymnostomum

Peristome lacking; leaf margins involute (forms of)......Weisia virdula

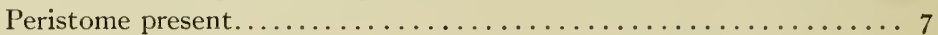

7--Leaves with margin more or less revolute (scarcely so in Barbula convoluta), curled or occasionally crisped when dry; basal cells rarely hyaline, usually yellowish or reddish .............. 8

Leaves with margin plane or involute; basal cells mostly hyaline; costa often excurrent; leaves usually crisped when dry ........ 9

8-Peristome teeth I6, more or less divided or perforate along the median line, erect or twisted to the right............. Didymodon

Peristome teeth 32 , filiform, strongly twisted to the left........ Barbula

9-Leaf margin strongly involute..................Weisia viridula

Leaf margin plane or leaves concave.................... Io

Io-Basal leaf cells hyaline, elongated-rectangular and extending obliquely up the margin; peristome of 32 long twisted teeth. Tortella

Basal cells not as above, or, if so, not extending up the margin; peristome of 16 untwisted teeth (in our species)............. II

II - Leaves as in Tortella, except that the hyaline cells do not extend up the margin..................... Trichostomum cylindricum 
Leaves with a lighter margin as in some species of Fissidens.

Desmatodon Porteri

I2-Costa excurrent Pottia

Costa ending below apex................. Hyophila

PHASCUM (L.) Schreb.

Is a genus clearly intermediate between the Ephemeraceae and the Tortulaceae, but more closely allied to the latter. Plants very small, growing close together, with short erect stem clearly marked, thus differentiating the genus from most of the Ephemeraceae. Leaves ovate to lanceolate and entire (in our species), papillose above. Capsule immersed or somewhat emergent, subglobose.

P. cuspidatum Schreb. Closter, Austin; Highbridge, N. Y.; New Dorp, S. Id., E. G. B., all at Bx! Also Musc. App. 53 from N. J. Early spring.

\section{Subfamily Weisieae}

Small persistent plants with stems usually short and rarely radiculose, not glossy. Leaves lanceolate or linear-lanceolate, equally spreading, usually keeled, seldom obtuse, twisted when dry, basal leaf cells hyaline and rectangular, upper almost always isodiametric and papillose; costa usually strong. Capsules mostly exserted (except in Astomum), small, symmetric,' oblong or ovoid, seldom cylindric, with stomata normally phaneropore, capsules cleistocarpous (in Astomum), gymnostomous, or peristomate. Peristome when present of 16 short, more or less imperfect, entire or somewhat divided, erect teeth.

\section{ASTOMUM Hampe}

Small gregarious mosses growing on soil. Leares crisped when dry, narrow, keeled; upper leaf-cells small, round, quadrate, papillose on both sides. Capsules immersed (in our species) subglobose, apiculate, of tentimes with a distinctly formed lid which can be removed but which does not fall of itself: calyptra cucullate.

Easily distinguished from Bruchia by its deeply immersed capsules, and from both Bruchia and Pleuridium by the leaves 
crisped when dry and strongly papillose on both sides; very strongly resembling sterile Weisia viridula.

A. Sullivantii (Schimp.) Hampe. Common in old fields, gardens and meadows. A. crispum and A. nitidulum have been frequently reported but my observations incline me to the belief that we have but one species. For a full discussion of the matter see Mosses with Hand-lens and Microscope, pp. I37-I39. The leaves are much like those of the next. Autumn to spring.

\section{WEISIA Hedw.}

Small mosses growing in tufts or mats on soil, especially rather dry sandy soil in our species, freely branching; upper leaves usually much larger than the lower, erect-spreading, strongly crispate when dry, elongated-lanceolate with the costa usually excurrent into a short point; basal cells rectangular and hyaline, the upper small roundish and thickly papillose with small papillae; capsule well exserted on a seta of moderate length, usually erect and symmetric, ovoid, plicate when dry and empty; peristome rudimentary, teeth short, sometimes perforate or somewhat divided, rarely almost lacking.

W. viridula (L.) Hedw. Very common in rather dry soil and occasionally growing in more moist situations. It is exceedingly variable in its peristome and its size. It may usually be distinguished from Astomum when sterile by its larger size and longer leaves.

Var. gymnostomoides (Brid.) Muell. "Rocky ground, Palisades of N. J.," Musc. App. 63.

\section{GYMNOSTOMUM Hedw.}

Plants dioicous, densely caespitose, ferruginous below, growing mostly in limestone regions. Leaves small, gradually increasing in size upwards, tufted at apex, scarcely crisped when dry, but somewhat twisted and appressed, linear-lanceolate to narrowly linear, costa and lamina papillose on both sides with rather low papillae; lower cells rectangular, upper roundish quadrate; capsule long-exserted, erect, symmetric, ovoid to oblong-ovoid, smooth and glossy when first ripe; peristome 
lacking, lid falling easily or remaining attached to the columella; calyptra cucullate, extending half way down the capsule.

Upper leaf cells minute, opaque; margin of leaves plane; operculum falling at maturity.............................. rupestre Upper leaf cells clear and pellucid, margin of leaf revolute on one side at least; operculum remaining attached to the columella..........curvirostre

All our species of Gymnostomum grow on wet ledges and cliffs in dense mats or cushions from $\mathrm{I}-\mathrm{IO} \mathrm{cm}$. thick. Some one of these species can be found on wet cliffs in almost any region fortunate enough to have the cliffs.

G. curvirostre (Ehrh.) Hedw. This species is put in the genus Hymenostylium by many recent authors. "Wet rocks, Godwinville, N. J.," Musc. App. 6r ; Little Falls, N. J., Austin, Bx!; Verplancks Point, N. Y., N. L. B., Bx!; "Bath, C. H. Hall," Flora of L. Id. Autumn.

G. rupestre Schleich. "Damp shaded rocks, rather common," Musc. App., 60; Hohokus and Little Falls, N. J., Austin, Bx!

\section{Subfamily Barbuleae.}

Plants usually with a reddish brown tinge, leaves gradually narrowed to the acute apex (except Barbula unguiculata and Tortella caespitosa). Costa usually vanishing into apex or slightly excurrent. Peristome as in the Tortuleae except that the basal membrane is always narrow.

\section{BARBULA Hedw.}

Leaves mostly lanceolate from a broader base, somewhat contorted when dry but scarcely crispate, margins revolute; upper cells small, roundish-quadrate, papillose, quadrate to rectangular and transparent to colored at base. Capsule oblong to cylindric, not altering when dry; operculum conic and beaked; peristome of 32 filiform twisted teeth.

I-Perichaetial leaves long- convolute-sheathing.............convoluta

Perichaetial leaves not conspicuously sheathing or different........ 2 2-Leaves usually obtuse and mucronate by the excurrent costa. 
B. convoluta Hedw. On ashes, Lakehurst, N. J.!!; Demarest, Hoboken and Palisades, N. J., Austin, Bx! According to R. S. Williams, Musc. App. I22 (Desmatodon arenaceus) is this species, at least in part.

B. fallax Hedw. On stones and soil, Hoboken, N. J., Austin, Bx! My specimen of Musc. App. 125 is B. unguiculata, at least in part. I have not examined the Hoboken specimen.

B. reflexa Brid. (B. recurvifolia Schimp.) is a variety or subspecies of $B$. fallax, distinguished by its reddish brown color, strongly squarrose-recurved lower leaves, broader, shorter and abruptly pointed. "On rocks, Hoboken, N. J.," Musc. App. Suppl. 496.

B. unguiculata (Huds.) Hedw. On damp earth and stones, frequent. Autumn to spring.

\section{DIDYMODON Hedw.}

Leaves mostly lanceolate from a broader base, somewhat contorted when dry but scarcely crispate, margins revolute; upper cells small, roundish quadrate, nearly smooth to strongly papillose, sometimes elongated and transparent at base. Capsule oblong to cylindric, not altering when dry; operculum conic and beaked; peristome of I6 teeth, undivided, perforate, or divided nearly to the base as in Ceratodon, short, not twisted.

D. rubellus (Hoffm.) B. \& S. "On rocks along streams, northern N. J.," Musc. App. I43. Summer to autumn.

\section{TRICHOSTOMUM Hedw.}

The genus differs from Didymodon in having the leaf-margins plane or incurved, and in the elongated-rectangular or linear basal cells. Distinguished from Tortella by the short untwisted peristome and the fact that the basal cells do not extend up the margin.

T. cylindricum (Bruch) C. Müll. (Didymodon cylindricus Wahl.) "Moist rocks and banks, Northern N. J., also Southern and Central N. Y.," Musc. App. I I4; Orange, Bry. Ct. Rarely fruiting. 


\section{TORTELLA (C. Müll.) Limpr.}

Usually growing in dense rather deep tufts, densely leaved. Much like Barbula, but the leaves are cirrhate-crispate (except $T$. fragilis) when dry, spreading to recurved, longer, elongatedoblong to linear-lanceolate with margins plane or involute; costa strong, ending in the apex or excurrent; upper leaf cells papillose with large papillae; basal cells sharply differentiated from the upper, hyaline, elongated and extending up the margins to a noticeable extent, rectangular, linear near the margins; peristome well developed and twisted.

All our plants of this genus have previously been included in Barbula by American authors.

\section{KEY}

I-Leaves long lance-linear, obtusely acute, abruptly mucronate by the

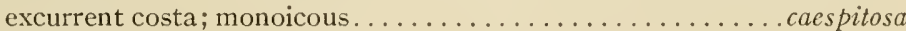

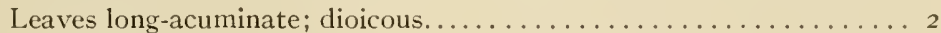
2-Leaves twisted crispate when dry, of one layer of cells throughout.

tortuosa

Leaves erect, rigid, much less contorted when dry, of two layers of cells above........................... fragilis

T. caespitosa (Schwaegr.) Limpr. "About the roots of trees, common," Musc. App. I27; Closter, Pompton, Palisades, N. J., Austin, Bx!; Richmond, S. Id., E. G. B., Southampton, L. Id., both at Bx!; Sandy beach, Orient, L. Id., Latham. Spring.

T. fragilis (Drumm.) Limpr. "Dry limestone rocks at the New Jersey Zinc Mines," Musc. App. I29.

T. tortuosa (I..) Limpr. "On rocks, common," Musc. App. I28. Usually sterile.

\section{Subfamlly Pottieae}

Leaves broad in outline and narrowed toward the base. Costa excurrent in most spẹcies. Calyptra cucullate; capsules gymnostomous (in our species).

POTTIA Ehrh.

Plants short, rarely branched, scattered or in tufts. Leaves soft, broad in outline, enlarging upwards, ovate to oblong, usually papillose (but not so in our most common species), 
costa reaching apex or beyond; areolation rather lax for the family. Capsule erect and exserted on a straight seta, ovoid to cylindric; peristome lacking in our species.

P. truncatula (I.) Lindb. ( $P$. truncata Fuern.) Hempstead, L. Id., New Dorp, S. Id., Bronx Park, E. G. B. All at Bx.; Hackensack, N. J., Austin. Bx! On soil in fields. Late autumn to spring.

\section{HYOPHILA Brid.}

Leaves subspatulate, more or less denticulate, slightly papillose, with costa ending below apex. Capsule narrowly cylindrical-oblong; peristome lacking.

H. riparia (Aust.) Fleisch. (Pottia riparia Aust.) "Moist rocks along streams, Palisades and northern N. J. \& southern N. Y.," Musc. App. II2; Hohokus, Pascack, and Little Falls. N. J., Austin. Rarely fruiting.

\section{Subfamily Tortuleae}

Leaves broad, oblong to spatulate or lingulate. Peristome of thirty-two long filiform spirally twisted teeth or of sixteen shorter scarcely twisted teeth. Costa nearly always excurrent.

Encalypta species are likely to be sought here, especially if sterile, but the papillae in Encalypta are very large and verrucose and the costa not excurrent or very shortly so. In $E$. streptocarpa, our most common species, the leaf margins are incurved above and the apex almost cucullate.

\section{DESMATODON Brid.}

This genus as a whole is scarcely distinct from Tortula, except that the basal membrane is very narrow or lacking, and the peristome is short and scarcely twisted, sonetimes so short as to be scarcely visible with a hand-lens.

D. arenaceus S. \& L. "On the ground near Closter and Soutiern N. J.," Musc. App. 122. According to R. S. Williams some at least of this number is Barbula convoluta.

D. Porteri James. Easton, Pa., Musc. App. I23. This is likely to be found nearer. 
TORTULA Hedw.

Plants robust, with large oblong or subspatulate leaves which are rounded at apex and usually have the costa long-excurrent, not crispate when dry, but somewhat twisted and contorted, mostly entire; upper leaf cells opaque and papillose (except T. mucronifolia), basal rectangular and hyaline or colored. Peristome teeth thirty-two, from a high basal membrane (except T. muralis), papillose and twisted to the left.

T. papillosa grows on tree trunks, the rest of our species on soil and stones. Distinguished from our species of Desmatodon by the high basal membrane and thirty-two spirally twisted teeth.

\section{KEY}

I-Growing on trunks of trees; leaves very concave, with costa very short-excurrent and bearing propagula; never fruiting......papillosa

Growing on soil and stones.......................... 2

2-Leaves with a short hair point, bordered with 2-4 rows of yellowish linear cells in two layers......................marginata

Leaves with a long hair point, not bordered............... 3 3-Hair point rough; basal membrane nearly equaling the teeth in length................................montana

Hair point smooth or nearly so; basal membrane narrow.......muralis

T. marginata (B. \& S.) Spruce. Palisades, N. J., Austin, Bx!

T. montana (Nees) Lindh. "Sunny rocks, usually calcareous, in inountainous or hilly regions," East Haven and Orange, Bry. Ct. "Foot of Palisades and Zinc Mines, Sussex Co., N. J.," Musc. App. 132. (As T. muralis var. mpestris.)

'T. muralis (L.) Hedw. "On old walls, Palisades and central N. J.," Musc. App. I30. Very common on mortared walls beside trolley line, Dongan Hills to New Dorp, S. Id.!!; Bronx Park, E. G. B., Bx!

T. papillosa (Muell.) Wils. Greenwood, I. Id., Brainerd (24284); "On trunks of shade trees, central N. J., also on limestone rocks about the Zinc Mines," Musc. App. I33; "Trunks ol buttonwood trees, Batsto, James," Flora N. J.; Hamden, Ct., Nichols, Bx!; Orange, Bry. Ct.; red cedars, St. John's Guild gate, S. Id., W. T. Davis, Bx!

Austin's habitat on rocks is very unusua!. 


\section{FAMILY 12. ENCALYPTACEAE}

The mosses of this family grow on soil or stones and are erect and usually caespitose. The leaves in our species are broad and lingulate or spatulate; lower leaf cells thin-walled and hyaline; upper cells small, dense and opaque, bearing strong verrucose papillae. The extinguisher-like calyptra is the most characteristic thing about the family, ard because of it these mosses are often called Extinguisher Mosses. The members of this family belong in the single genus.

\section{ENCALYPTA Schreb.}

which is so much like some species of the Tortulaceae that Brotherus in "Die Planzenfamilien" makes it only a subfamily of the Tortulaceae. In many respects our species strongly resemble the species of Tortula. The leaves are large and tongue-shaped and are twisted when dry, but the costa is little or not at all excurrent. In fruit, the peristome and the characteristic calyptra are enough to render identification easy, in sterile plants the beginner might make a mistake. The plants are much too large to be confused with Desmatodon, and the percurrent or barely excurrent costa distinguishes from all of our species of Tortula except T. papillosa, which has simple papillae, or $T$. mucronifolia, which has no papillae at all.

In Encalypta we have a curious combination of peristome characters; the striking similarity of the calyptra and leaves in the various species makes it rertain that no mistake is made in putting them all in one genus; yet within the limits of this one genus we have almost all degrees of completeness of the peristome, from none at all to one highly developed and double. Some of the peristomes show a strong likeness to the nematodont type, while in E. procera there is an almost typical arthrodont double peristome.

Leaves apiculate to acuminate $\ldots \ldots \ldots \ldots \ldots \ldots \ldots \ldots \ldots \ldots \ldots$ ciliata Leaves obtuse............................... streptocar pa

E. ciliata (Hedw.) Hoffm. "Wet rocks near Haverstraw, N. Y.," Musc. App. I74. 
E. streptocarpa Hedw. "On limestone rocks, Sussex Co., N. J.," Musc. App. I75; Swartswood, N. J., IViegmann.

\section{GROUP 2. DIPLOLEPIDEAE}

Peristome double, the plates of the outer side of the teeth (outer peristome) in two rows, separated by a zigzag median line; inner side of teeth of a single row of plates.

Inner peristome thin and membranous, made up of the inner walls of the same cells whose outer walls formed the inside plates of the teeth. The teeth of the inner peristome are known as segments, and are usually $\mathbf{I} 6$, alternating with the teeth, somewhat keeled, usually arising from a basal membrane $\frac{1}{6}$ to I/2 the height of the teeth, and in the highest development separated by $\mathrm{I}-3$ hair-like cilia of varying lengths. The segments may be opposite the teeth and without basal membrane or cilia as in Funaria. The segments themselves may be reduced to a mere filament, as in Orthotrichum. The entire inner peristone may be lacking in degenerate types, as in some species of the Bartramiaceae, or even the entire peristome may be lacking, as in Physcomitrium.

\section{Subgroup 1. Acrocarpeae}

Sporophyte terminal from erect, or nearly erect stems, sometimes becoming lateral by innovations. In these respects the plants of this subgroup are like most of those of the preceding families.

\section{FAMLLY I3. ORTHOTRICHACEAE}

This family somewhat resembles the Grimmiaceae, but nearly always grows on trees. The plants are small, rarely reaching an inch in height and usually much shorter, blackish or brownish green below; nearly always growing in tufts or cushions. The leaves are oblong- or linear-lanceolate and usually very hygroscopic; cells of the upper part hexagonal to roundedhexagonal, thick-walled and often papillose; lower cells oblong to rectangular, rarely papillose, thinner walled in most cases, and of ten hyaline; costa single, strong. The calyptra is nearly always hairy and the capsules often immersed, with very distinct longitudinal wrinkles when dry and empty. The peristome usually 
consists of 16 rather short teeth, which are nearly always reflexed when dry and are often united in pairs; the inner peristome is usually represented by 16 slender hairlike processes, often called cilia, but really homologous with the segments of the type of peristome found in Mnium and Hypnum. In some cases the peristome may be simple or even wanting, as in Amphidium. This family is often united with the Grimmiaceae, from which it is distinguished by the italicized characters. Members of these two families may become so dry and brittle as to crumble to dust in the fingers and yet retain their vitality unimpaired, springing into renewed growth with the next rain.

\section{Key to the Genera}

I-Calyptra smooth, cucullate; peristome none or very short and single; rock-growing except Drummondia.................. 2

Calyptra mitrate, nearly always hairy; peristome well developed, almost always double; growing almost exclusively on trees...... 3

2-Tree-growing; capsule long-exserted; peristome single, short and truncate. Common......................... Drummondia

Rock-growing; capsule barely exserted; peristome lacking ...A Amphidium 3-Capsule exserted; leaves crisped, except U. A mericana.......... Ulo:a Capsule immersed or emergent; leaves not crisped when dry.

Orthotrichum

\section{AMPHIDIUM (Nees) Schimp. (Amphoridium and Zygodon} of authors)

Slender-stemmed dichotomously branching plants growing on rocks, usually in dense tufts from $3-8 \mathrm{~cm}$. in depth, rather densely radiculose. Leaves linear to lance-linear, twisted and contorted to crispate; costa strong, reaching nearly to apex; upper leaf cells small, thick-walled, rounded or angular, said to be papillose but the papillae are very low and inconspicuous; basal cells becoming gradually elongated-rectangular and thinner walled, also lighter colored or even hyaline. Calyptra cucullate, without hairs. Capsules erect, emergent or exserted, with a distinct neck, becoming urn-shaped and 8-striate when dry; peristome none.

Both species mature their spores in summer.

Autoicous; leaf margins plane; seta $1.5 \mathrm{~mm}$. long or less.......lapponicum Dioicous; leaf margins recurved below: seta about $3 \mathrm{~mm}$. long.... Mougeotii 
A. lapponicum (Hedw.) Schimp. "Crevices of rocks, northern N. J.," Musc. App. I54.

A. Mougeotii (B. \& S.) Schimp. "Wet rocks with the preceding," Musc. App. I55; Handen, Bry. Ct.

\section{DRUMMONDIA Hook.}

Drummondia usually grows on the bark of trees, but is easily distinguished from its tree-growing allies by three characters. Its stems are long and closely applied to the bark of the tree, sending out short horizontal branchlets so thickly that the stems below become apparent only when the plant is removed. The capsule is on a long seta, the calyptra is cucullate, and the peristome is so small as to be scarcely apparent.

D. clavellata Hook. On trunks and branches of trees, particularly Juniperus Virginiana, and on old stone fences, very common," Musc. App., 152 ; Cold Spring, Jamaica and Ridgewood, Lloyds Neck and Greenwood, L. Id.; Bedford, N. Y. Summer.

\section{ULOTA Mohr.}

The species of Ulota have the characteristic brownish-green or blackish-green color of the Orthotrichaceae. They are distinguished from all save Orthotrichum by the hairy calyptra. Both Orthotrichum and Ulota grow on the bark of trees or more rarely on rocks, in cushions of varying size and thickness. Ulota growing on trees usually grows in more rounded tufts, with the leaves more crisped when dry than is usual with Orthotrichum growing in similar situations. The median basal leaf cells are often nearly linear, upper cells slightly papillose to smooth. The books all say that the hairs on the calyptra of Ulota are flexuous, and those on Orthotrichum straight, but this distinction appears to be rather too fine for the amateur to profit by it. The capsules in both genera are erect and symmetric and quite regularly striate when dry, with eight or sixteen ridges and as many alternating furrows. These ridges consist of cells larger, darker, and thicker-walled than the alternating tissue. The peristome may be single or double. The seta in Orthotrichum is so short that the capsule is nearly always partially 
immersed; in Ulota the seta is long enough to exsert the capsule entirely beyond the perichaetial leaves.

'The remarks in the discussion of Orthotrichum on the condition of capsules suitable for study apply equally to Ulota.

KeY

I-Growing on rocks; leaves not crisped. Americana

Growing on trees; leaves crisped when dry................ 2

2-Capsule abruptly narrowed to the small mouth. smooth except near

the mouth ............................... Ludwigii

Capsules wide mouthed, distinctly plicate.....crispa and var. crispula

U. Americana (Beauv.) Lindb. Common; reported as occasionally occurring on trees. Summer.

U. Ludwigii Brid. On trees, Closter, N. I., Austin, Bx! Autumn.

U. crispa Brid. Frequent in outlying districts. Springsummer.

Var. crispula (Bruch.) Hamm. "On trees, particularly Betula lutea, rather scarce," Musc. App. I59; Closter, N. J., Austin, Bx!; Jamaica L. Id., Brainerd (H. S.)

\section{ORTHOTRICHUM Hedw. (Plate IV.)}

Plants comparatively short-stemmed, in close rounded cushions, sometimes looser, on trees everywhere, and more rarely on rocks. Leaves hygroscopic, imbricated when dry and not greatly curled or twisted, which character separates the genus from Ulota except $U$. Americana. Upper leaf cells usually papillose, thick-walled, the lower thinner-walled and quadrate to rectangular. Calyptra sparsely hairy or naked. Base of seta enclosed in a minute cup-like sheath, the ochrea. Capsule immersed or emergent, rarely exserted; usually with 8 regular folds, or plicae, when dry, but sometimes smooth or with I6 plicae. Peristome usually double, with 16 broadly lanceolate teeth, which are usually united in pairs. Inner peristome of 8I6 narrow segments, often called cilia. The paired (bigemminate) teeth and degenerate inner peristome illustrate well the degeneracy of peristomes on erect capsules.

The Orthotrichums are most frequent on trees about houses, and in orchards and village streets, although they are not lack- 
ing in other situations where the trees stand somewhat apart. They can be found abundantly on almost any fruit or shade tree in the country. In the larger cities, for some reason, they do not seem to thrive. They may frequently be found growing with Ulota, from which the immersed or emergent capsule and non-crisped leaves distinguish them at once. The calyptras are less densely hairy than those of Ulota. Two species have a calyptra without hairs. The leaves have revolute margins, except in $O$. obtusifolium. Drummondia has the general appearance of an Orthotrichum with an exserted capsule, but the calyptra is cucullate and without hairs and the capsule is not wrinkled when dry.

Sterile specimens are often indeterminable. The stomata furnish an excellent and definite microscopic character and are easily observed by separating a capsule into two or more divisions with the dissecting needles and mounting outside up; the stomata are nearer the middle of the capsule than in many mosses and are therefore, easier of observation. The condition of the material is of the utmost importance. The capsule must be thoroughly soaked in hot water for a long time to be fully expanded, and the dry capsule must be thoroughly dry to be characteristic. 'The capsules of all species shrink progressively with increasing age, and many varieties had their origin in this fact. The plants should be moistened to determine whether the capsules are immersed, emergent, or exserted. The peristomes are of ten quite brittle and are apt to be broken, especially the segments. For identifying species, perfect calyptras are of the greatest value and importance.

\section{KEY}

I-Rock-inhabiting species; peristome single, teeth I6, erect or erectspreading on dry capsules, stomata immersed ............ 2

Tree-inhabiting species; peristome double, teeth usually united into 8 pairs, recurved or reflexed when dry ................

2-Capsule fully exserted, I6-striate.................. anomalum

Capsule immersed or emergent, 8 -striate................ 3

3-Capsule ovate-cylindric, urn half emergent when dry..........Porteri

Capsule much shorter, ovate-globose, leaves nearly reaching mouth

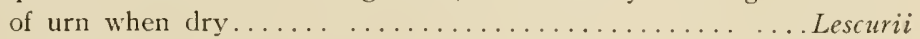
4-Stomata superficial (i.e., with both guard-cells on the surface) $\ldots .5$

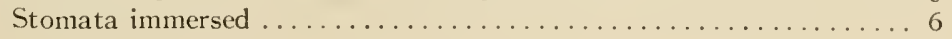


5-Capsule smooth, or very slightly plicate around the mouth when

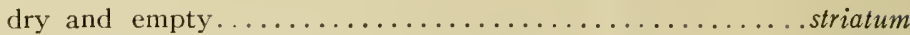

Capsule plicate the whole length when dry............... sordidum

6-Capsules strongly contracted under the mouth when dry, and so strongly plicate that the red-brown folds are almost in contact on the outside when dry and empty .............. strangulatum

Capsules very slightly or not at all contracted, much less strongly

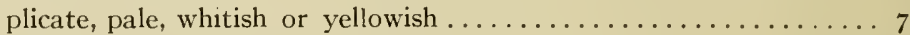

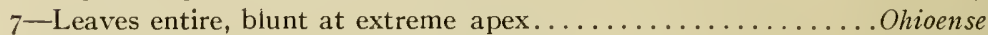

Leaves (some at least) dentate with projecting cells, often apiculate. . 8

8-Leaves mostly acute at apex, not rounded; usually some with an apiculus of a single projecting cell; capsules plainly 8 -plicate when

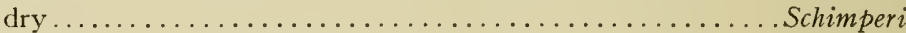

Leaves obtuse, rounded and some sharply denticulate at apex with several projecting cells; capsule smooth or faintly 8 -plicate when

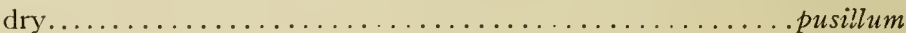

O. anomalum Hedw. Rocks, Palisades, Flora N. J.: Branford, Bry. Ct. May-June.

O. Lescurii Austin. "On dry shaded rocks, northern N. J. and southern N. Y.," Musc. App. I63; Pascack and Palisades, N. J., Austin, Bx!

O. Ohioense S. \& L. College Point, Jamaica, and Sag Harbor, L. Id.; New Dorp, S. Id.; Bedford, N. Y.; "On trees, N. J. and N. Y.," Musc. App. I7o (As O. Citrinum); Trumbull, Ct. April.

O. Porteri Aust. "On dry limestone rocks, Sussex Co., N. J. and Orange Co., N. Y.," Musc. App. I62 (as O. Peckii); on rocks near Jerome Ave., Mott Haven, Sanial, Bx!

O. pusillum Mitt. "On shade trees, central N. J.," Musc. App. 171; Little Falls, N. J., Sanial, Bx!; Rockland Lake, N. Y., Jelliffe, Bx!; New Dorp, S. Id., E. G. B., Bx! May.

O. sordidum S. \& L. "On trees, N. Y. and N. J., very common," Musc. App. I68; On red cedars, New Dorp and on willows back of mausoleum, Todt Hill, S. Id., E. G. B., Bx!; Cold Spring, L. Id.!! Spring-summer.

O. Schimperi Hamm. "On shade trees in towns and villages of central N. J.," Musc. App. I65: New Dorp, S. Id., Van Cortland Park, Bronx Park, E. G. B., Bx! Spring. 
O. strangulatum Sulliv. Frequent. May-June.

O. striatum (L.) Hedw. "On red cedars, Palisades, rare," Musc. App. I72.

\section{FAMILY 14. SPLACHNACEAE}

The mosses of this family are rather short-stemmed with leaves distant and flaccid, with a loose areolation, not papillose. The calyptra is cucullate, or entire and conical. Capsules erect and symmetric, with a very pronounced and characteristic hypophysis, which in some species is so exaggerated as to become a striking natural curiosity The peristome is single in all our species. The teeth are often united in pairs or more rarely in fours, much as in Orthotrichum, and are sometimes reflexed as in that genus. The hypophysis is well supplied with stomata and is made up of loose tissue well adapted for the assimilation of carbon dioxide.

The mosses of this family nearly all grow upon decaying animal tissue or upon animal excreta, more rarely upon decaying vegetable matter, and this, taken in connection with the peculiar hypophysis, makes fertile plants unmistakable. The flaccid leaves, with their loose areolation, distinguish sterile forms from most mosses except, perhaps, the Funariaceae and Meeseaceae.

\section{TETRAPLODON B. \& S.}

T. australis S. \& I.. "On excrement of herbivorous animals in the cedar swamps of southern N. J., frequent," Musc. App. I 77 .

Splachnum ampullaceum L. is reported from Quaker Bridge, Burlington Co., in Geol. Survey N. J.

\section{FAMILY 15. FUNARIACEAE}

Plants annual, sometimes biennial, growing on soil that is bare or sparsely covered with other vegetation, rather short with large wide soft leaves much like those of the last family, usually having a well developed costa extending, in most cases, well toward the apex. The leaf cells are parenchynatous, 
large and thin-walled, elongated hexagonal to oblong above, usually rectangular at base. Capsules subglobose, oroid, or pyriform, erect and symmetric, or strongly unsymmetric and sometimes cernuous, often with a distinct neck. Peristome lacking or single or double. The teeth when present are I6, and the segments are opposite the teeth instead of alternate with them as in Mnium or Hypnum. There is no basal membrane or intermediate cilia. Calyptra of ten inflated, usually with a long beak, cucullate or often split in two or more places. I have followed Brotherus in including the Ephemereae.

\section{KEY}

Stem erect, mostly simple; seta in most cases more or less elongated; capsule alwayss exserted usually opening by a distinct lid. . Funarieas

Plants very small, almost stemless, from a persistent protonema; seta rudimentary or lacking; capsules immersed, mostly cleistocarpous.

Ephemereae

\section{StBFAMILY FüARIEAE \\ KEY TO GENERA}

I-Capsules erect and symmetric; peristome lacking............ 2

Capsules strongly unsymmetric; peristome present, usually double.

Funaria

2-Capsules exserted on a long seta...........Physcomitrum turbtnatum

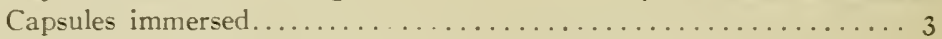

3-Capsule splitting exactly in the middle, with no specially modified cells aiong the line of dehiscence; angles of cell walls of capsule thickened (collenchymatous) . . . . . . . . . . . . A phanorrhegma

Capsule dehiscing by a regular lid having I-3 rows of denser cells around its mouth; cell walls of capsule collenchymatous.

Physcomitrum immersum

\section{APHANORRHEGMA Sulliv:}

A small genus of only two known species. It seems to differ from Physcomitrium chiefly in the much less differentiation of the tissues along the line of dehiscence of the capsule.

A. serratum Sull. "On damp ground, common," Musc. App. I 8 ; Closter, Austin; three localities at New Dorp, S. Id.; and two in the Bronx, E. G. B.; all at Bx! Sept.-Dec.

PHYSCOMITRIUM Brid. (Plate VI, Fig. I.)

Mostly small light green plants sparingly branching. Leaves oblong, obovate, spatulate or broadly oblanceolate. Calyptra 
small, mitrate, usually covering less than $1 / 2$ the capsule. Capsule on a long seta, in a few cases immersed, erect, symmetric, with a distinct lid but no peristome; annulus present, often persistent.

P. turbinatum (Mx.) Brid. On bare soil and in fields. Very common and freely fruiting. Early spring with the blue violets.

P. immersum Sull. Banks of the Delaware, Camden, N. J., Austin and James. See Musc. App. I79; see also Bull. Torr. Bot. Club, 2 I : I90. 'This must occur nearer to N. Y. City. It is the only species maturing its spores in the fall and is likely to be niistaken for Aphanorrhegma. The latter splits exactly along the middle line and has cell walls of capsule collenchymatous.

FUNARIA Schreb. (Plate V, Fig. 2.)

Funaria strongly resembles Physcomitrium in everything except sporophyte characters. Calyptra inflated at base, finally oblique with base cucullate. Capsule more or less gibbous, narrowed to a rather short neck, wrinkled to strongly sulcate when dry; mouth more or less one-sided. Peristome double in our species; teeth 16 , often twisted spirally and united at their tips; segments I6; opposite the teeth, without basal membrane or intermediate cilia.

Leaves long acuminate, costa excurrent in some of the leaves of each plant ................................flavicans Leaves short acuminate, costa percurrent, sometimes very shortly ex-

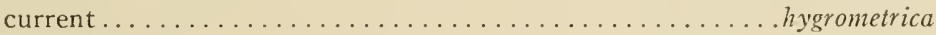

F. hygrometrica (L.) Sibth. Common on soil recently disturbed or burnt over, also on basement walls of houses and mortared walls. Spring.

F. flavicans Mx. Flatbush, Brainerd (2456I); Yard, 360 I.enox Rd. Brooklyn!!; Orient, L. Id., Iatham; Closter, N. J., Austin; Lakehurst, N. J.!!; Bedford Park, R. S. Williams!!

\section{Subfamily Ephemereae}

Exceedingly minute plants, about I $\mathrm{mm}$. to $2 \mathrm{~mm}$. high, stemless, usually with persistent protonema, usually scarcely visible except as a green film over the soil, composed merely of 
a bud-like cluster of leaves enclosing the subglobose cleistocarpous capsule. Leaves minute, leaf cells rhomboid-hexagonal, longer below, shorter above, smooth, or slightly papillose in one or two species of Ephemerum; costa present, except in Nanomitrium and some species of Ephemerum.

Growing on bare, moist earth.

\section{Key to the Genera}

I-Green protonema persistent, leaves lanceolate............. 2

Green protonema not persistent, leaves ovate......................

2-Capsule wall colorless, of a single layer of cells, without stomata; rudimentary operculum well differentiated and easily separating when mature capsules are pressed..................

Capsule wall colored, of more than one layer of cells, with stomata; operculum not differentiated, capsules dehiscing irregularly. Ephemerum

\section{NANOMITRIUM Lindb. (Micromitrium Aust.)}

Resembling E.phemertm, but differing in the characters mentioned in the key and in the usually smaller capsule almost without apiculus and the minute persistent calyptra. The leaves are ecostate and the columella lacking in mature capsules. Salmon's figures show a single row of transversely elongated cells extending around the capsule between lid and urn. These cells are almost linear in shape and break upon pressure, thus causing the lid to separate and open the capsule. The plants of this genus are said to be rather rare, but this probably is because of their small size, which renders them so inconspicuous that they are rarely collected. Apparently the spores mature in late autumn to early spring.

N. Austinii (Sulliv.) Lindb. "On wet broken ground in woods, Closter, N. J.," Musc. App. 45; Rockland Co., N. Y., Austin, Bx!; Hamden, Ct., Nichols, Bx!

N. synoicum (James) Lindb., distinguished from Austinii by the entire leaves, has been found at Camden and Swedeboro, N. J., and probably will be found nearer.

\section{EPHEMERUM Hampe}

Minute plants developed on a persistent, much-branched, green protonema. Leaves lanceolate to narrowly ovate-lanceolate, costate except in E. serratum and E. megalosporum; capsules 
immersed, cleistocarpous, subglobose, minutely apiculate, colored, possessing spore-sac and a columella which may be partially absorbed at maturity; stomata present; capsules dehiscing irregularly; calyptra small, campanulate, torn at base but sometimes on one side only. Spores maturing in late autumn to early spring.

The very abundant protonema in this and in Nanomitrium is a striking feature, as it of ten almost obscures the plant when mounted under the microscope.

KEY

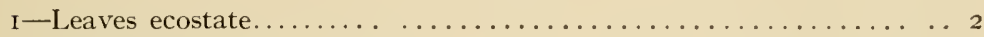

Leaves costate................................... 3

2-Leaves strongly serrate; stomata at bese of capsule only...... serratum

Leaves very slightly serrulate above; stomata on the upper part of capsule ..............................megalosporum

3-Calyptra papillose, leaves papillose both sides........... papillosum

Calyptra smooth............................... 4

4-Costa excurrent into a long spinulose awn-like acumination which constitutes the greater portion of the leaf above the capsule. spinulosum

Leaves gradually long-acuminate, scarcely serrate at apex...... sessile Leaves gradually long-acuminate, strongly serrate at apex.crassinervium

E. crassinervium (Schwaegr.) CM. "On damp ground, very common," Musc. App. 48 (in part); Closter and Palisades, N. J., Austin, Bx!; Batsto, N. J., James.

E. megalosporum (Aust.) Salmon. Closter, N. J., Austin, Bx!; Orange, Bry. Ct.

E. papillosum Aust. "On thin soil and rocks, Palisades, N. J.," Musc. App. 50.

E. serratum (Schreb.) Hampe. "Fields and gardens near Closter, N. J.," Musc. App. 47b; ten collections from S. Id., mostly near New Dorp, E. G. B., Bx!

E. sessile (B. \& S.) CMI. "Closter, N. J., Austin," L. \& J. Manual: 39 .

E. spinulosum Schimp. "Inundated or wet places, very common," Musc. App. 49; New Dorp, S. Id., and Bronx Park, E. G. B., Bx! 


\section{ACAULON C. Muell.}

The species of this genus are distinguished by their broadly orate loosely areolate smooth costate leares; leares and leaf cells broader and proportionately shorter than in Ephemerum, but growing in the same situations. Early spring.

Perichaetial and upper leaves carinate, margins reflexed........triquetrum Perichaetial and upper leaves concave, margins plane...........rufescens

A. rufescens Jaeg. Fields Brooklyn, Austin (24270)!; "old fields, N. J.," Musc. App. 5I ; Closter, Austin, Bx!; Tottenville, S. Id., E. G. B., Bx!

A. triquetrum (Spruce) CM. "Sandy fields, Toms River, N. J.," Musc. App. 52.

\section{FAMILY i6. MEESEACEAE}

Plants of wet boggy places, frequently growing with Sphagna. Leaves spreading to squarrose-recurved, of a rather firm structure, ovate-lanceolate to elongated-lanceolate. Costa long and stout, ending a little below the apex. Leaf cells smooth (papillose in Paludella), rather small above, large and more elongated below. Seta usually very long and slender. Calyptra cucullate. Capsules curved-pyriform, with a conspicuous neck, smooth or somewhat striate when dry; operculum small, short conical; mouth small; annulus of one or two rows of cells; peristome double, the inner usually much longer than the outer and consisting of 16 narrow segments alternating with the teeth, cilia sometimes present.

All of our mosses of this family seem to be rather rare. The bog habitat, the long seta and the curved pear-shaped capsules with a small mouth, clearly establish the identity of any member.

MEESEA Hedw.

Stems more or less elongated and radiculose. Upper leaf cells rectangular to hexagono-rectangular. Neck of capsules long; segments of inner peristome often united by lateral hairlike appendages bearing nodules; teeth short, usually obtuse. The spores of our species ripen from late June to August.

M. triquetra (L.) Angstr. "Wet meadows, Closter, N. J.," Musc. App. $21 \%$. 


\section{FAMILY I7. TIMMIACEAE}

Tall robust mosses resembling Polytrichum in appearance when sterile; growing in deep loose tufts on soil and rocks. Leaves lanceolate from an appressed sheathing base, serrate above, strongly costate to apex, but costa much narrower than in Polytrichum, and entirely without lamellae; leaf cells small, round-hexagonal, smooth or rarely lightly papillose. Calyptra cucullate; seta long; capsules of ten somewhat wrinkled when dry, but scarcely plicate or sulcate, when fresh resembling those of Mnium and Bryum. Peristome like that of Mnium, except that the inner is composed of cilia only, which are grouped together in fours.

TIMMIA Hedw. (Our only genus)

T. cucullata Mx. (as T. megapolitana Hedw.). Yonkers, E. C. Howe (Bx.)!; "Banks of ravines, Northern N. J.," Musc. App. 227; Pascack, N. J., Austin, Bx!

\section{FAMily 18. AULACOMNIACEAE}

Intermediate between the Bartramiaceae and the Mniae, with some characters of the Meeseaceae. From the Mniae it differs in the much smaller papillose leaf cells and in having the capsule regularly striate or sulcate when dry. From the Bartramiaceae it differs in the larger broader leaves and the more elongated and less unsymmetrical capsules with welldeveloped cilia in the inner peristome. It differs from the Meeseaceae, except Paludella, in the perfectly developed peristome, less conspicuous neck of the capsule, and the papillose leaf cells.

\section{AULACOMNIUM Schwaegr.}

Usually caespitose, growing on soil in moist woods or in bogs; green above; of ten brown or brownish green below; stems of ten densely matted with radicles. Leaves large, strongly costate nearly or quite to the apex; leaf cells small, rounded, strongly thickened at the angles (collenchymatous), in most species strongly papillose on both sides, each cell bearing a single 
large papilla in the middle of each surface. Branches frequently terminating in flagelliform pseudopodia bearing propagula at their tips; calyptra cucullate; capsule oblong to subcylindric, cernuous and usually somewhat unsymmetric, with a short neck (so short as to be easily overlooked in some species), regularly plicate or sulcate when dry. Annulus early deciduous. Peristome perfect, as in Mnium.

Leaves broad. apex rounded or acutish, strongly serrate; monoicous.

heterostichum Leaves lanceolate, acute, serrate or crenulate at apex; dioicous....palustre

A. palustre Schwaegr. Common everywhere in swamps!! June.

A. heterostichum (Hedw.) B. \& S. Frequent, preferring soil at base of trees in moist woods. May-June.

\section{Family i9. BARTRAmiaCEAE (Plate V, Fig. I.)}

Plants of medium or large size, usually growing in large deep tufts or cushions on soil or rocks in moist shaded places; of ten developing whorled innovations below the places where archegonia or antheridia have been produced. Leaves strongly costate to near the apex or beyond, acute, papillose (except Bartramia Oederi), usually serrate. Leaf cells roundish-quadrate to rectangular. Calyptra small, cucullate; seta rather shorter than in the related families; capsule nearly globular, usually without neck, usually cernuous and somewhat unsymmetric, regularly plicate or sulcate when dry; peristome double in all our species; cilia frequently rudimentary or lacking; segments split along the median line and the halves widely divergent, sometimes appearing as if bordering the teeth.

\section{Key to Genera}

Leaves elongated-lanceolate to linear-lanceolate; inner peristome with cilia rudimentary or lacking........................... Leaves much shorter, ovate-lanceolate; cilia present...........Philonotis

\section{PHILONOTIS Brid}

Our species of this genus are water-loving mosses, growing on wet banks and rocks where water trickles, or on the margins 
of pools or streams. The stems are densely radiculose below. This genus differs from Bartramia chiefly in the characters mentioned in the key and in the much more slender habit, with a strong tendency to the whorled innovations mentioned above. The plants are nearly always dioicous and the perigonial leaves are made the basis of specific distinctions in this genus to a very unusual extent.

P. fontana (L.) Brid. "Huntington and Northport, Sanial," Mosses of L. Id.; "Banks of rivulets in springy places, common," Musc. App. 223; Suffern, N. Y., Musc. App. 224. May-June.

P. Muhlenbergii (Schwaegr.) Brid. "Wet banks, Sussex Co., Rau; Newfoundland, Mrs. Britton," Geol. Surv. N. J.

\section{BARTRAMIA Hedw.}

Bartramia grows in moist niches in cliffs and on moist shady banks, looking much like tufts of green wool. The capsules are globular and somewhat unsymmetric when moist, but dry with regular folds and alternate ridges. When very dry the body of the capsule becomes so shrunken as to be smaller than the mouth of the capsule itself. The leaves are long and slender and somewhat curled when dry, and strongly papillose. $B$. Oederi is somewhat of an exception as regards leaf characters, and by recent writers is put in the genus Plagiopus.

Leaves lanceolate, not papillose

Oederi

Leaves nearly linear, very long and narrow, papillose

pomiformis

B. pomiformis (L.) Hedw. Shaded banks; occasional. Cold Spring, Oyster Bay and Roslyn, L. Id.; Princess Bay, S. Id.; Bronx Park, Eastchester, High Bridge, Riverdale; "very common," Musc. App. 22 I ; also Palisades and Toms River, N. J. April-May. (Plate VII, Fig. I.)

B. Oederi (Gunn.) Sw. Yonkers, Southworth, Bx!; “Banks of ravines Northern N. J.," Musc. App. 222. May-June. 


\section{FAMILY 20. BRYACEAE}

For the most part large conspicuous mosses growing in close tufts, or loosely aggregated, or scattered; some forms spreading by stolons have the habit of sterile pleurocarpous mosses. Leaves usually large, smaller below and increasing in size upward to the upper, which often form a distinct comal tuft, all supported by a strong costa which extends nearly to the apex, or may be somewhat excurrent, and in many species by a thickened border of narrower elongated cells. Leaf cells large and comparatively thin-walled, short and broad in the Mnieae, longer and narrower in the Bryeae. A few species are small with small leaves, but with the characteristic sporophyte of the family. Calyptra cucullate. Capsules proportionately large, pendent or drooping, of ten light-colored, not striate or plicate when dry, usually symmetric. Peristome characteristically perfect, cilia sometimes rudimentary or lacking.

\section{KEY to StBFAMILIES}

Plants larger; leaf cells not more than twice as long as broad; cilia not appendiculate (Rhodobryum will be sought here)........... Mnieae

Plants usually smaller; leaf cells more than twice as long as broad; cilia often appendiculate, occasionally wanting............... Bryeae

\section{Subfamily i. BRYEAE}

I-Plants large, with the habit of a large Mnium. from creeping, rhizome-like stolons; upper leares in rosettes $12-20 \mathrm{~mm}$. across; capsules clustered............................ Rhodobryum

Plants smaller, without rhizomelike stolons............... 2

2-Leares ovate to ovate-lanceolate; leaf cells rhombic to rhombichexagonal, never linear except at margins................ +

Leaves linear-lanceolate or narrower (the lower are often broader); leaf cells narrowly rhombic to linear...................

3-Leares linear from a broader base, hairlike; cilia appendiculate.

Upper leaves linear-lanceolate; cilia not appendiculate, sometimes Leptobryum

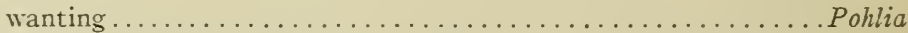

4-Leares not bordered; dioicous; annulus lacking; stonata immersed; leaf cells long and lax; growing in water or very wet places.

Mniobry'um

Leares often bordered; inflorescence various; stomata superficial; leaf cells usually shorter........................ Bryum 
With the exception of Rhodobryum, Leptobryum, Plagiobryum, Bryum argenteum and possibly Mniobryum, it is extremely difficult to determine species of this subfamily unless perfect fruiting specimens can be obtained. It will be a discouraging task to any one except a specialist in the group, and one not worth while under any ordinary circumstances.

\section{LEPTOBRYUM Schimp.}

L. pyriforme (L.) Wils. Moist cliffs and stones, fields and mortar in basement walls of houses and walls; also greenhouses; frequent. June-July.

POHLIA Hedw.

Plants tufted, usually growing on moist soil and stones. Lower leaves shorter, ovate-lanceolate as a rule, the upper longer, the comal usually linear-lanceolate; costa ending just below apex, percurrent or rarely excurrent; leaf cells narrowly rhomboidal to linear; capsule pear-shaped or clavate, usually with a proportionately long tapering neck; cilia of inner peristome not appendiculate.

This subgenus is sometimes treated as a subgenus of Bryum, from which it differs in little except the narrower areolation and narrower comal leaves.

I-Capsules very short and small; stems not red ........... Lescuriana

Capsules larger and longer; stems often red when old.......... 2

2-Bearing gemmac in the axils of the leaves of the sterile stems; dioicous; infrequent or rare..................... proligera

Not producing gemmae; never wholly dioicous, sometimes polygamous. 3

3-Infrequent, growing principally in the mountains: leaf cells very long and narrow, linear-vermicular, II-I6: I; lower leaves large,

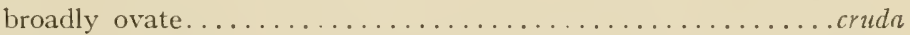

Common everywhere; leaf cells broader; lower leaves smaller than in

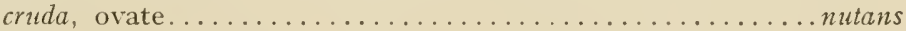

P. cruda (L.) Lindb. Alpine, N. J., Austin; Yonkers, Southworth; Kreischerville, S. Id., E. G. B., all at Bx!

P. Lescuriana (Sulliv.) Grout. "On banks along roadsides, Palisades, northern N. J. and southern N. Y.," Musc. App. I90; frequent on Staten Island!! Spring. 
P. nutans (Schreb.) Lindb. Common in swampy places. Early summer.

P. proligera (Lindb.) Correns. Roadside bank, N. Y. Bot. Gardens, E. G. B., Bx!; banks of brooks, Richmond and Rossville, S. Id!!; Beacon Falls, Hamden, and New Haven, Bry. Ct.

\section{MNIOBRYUM (Schimper ex parte) Limpr.}

All species dioicous; antheridia in the axils of the perigonial leaves. Leaves serrate at apex, not margined, but marginal cells somewhat narrower than the median; leaf cells as a whole broader than in Bryum but longer and narrower than in Mnium, thin-walled. Capsules pendent, small and short, pear-shaped; stomala immersed; annulus lacking; peristome perfect. Plants of wet places, such as springs, ditches, banks of streams and ponds.

M. albicans (Wahlenb.) Limpr. (Bryum Wahlenbergii Schwaegr.) "On moist rocks and banks, common but rare in fruit," Musc. App. I89; Bronx Park and S. Id., E. G. B., Bx!; Richmond, S. Id.!!; Orient, Latham.

\section{BRYUM Dill. (Plate VI, Fig. 2.)}

Plants densely tufted, interwoven with radicles, usually with branches arising below the "flowers." Leaves ovate to lanceolate, thin and very little hygroscopic, rarely obtuse; cells smooth, rather large, rhombic to hexagonal, quadrate to rectangular at base, the marginal often very narrow and forming a more or less distinct, sometimes thickened border; costa usually excurrent. Capsule on a long seta, usually more or less pendulous, pyriform but varying from subglobose to elongated-clavate, usually symmetrical; operculum conical, usually apiculate but never rostrate; annulus present; peristome of I 6 long-lanceolate, closely articulate teeth; the inner of a basal membrane about half the length of the teeth, bearing i 6 lanceolate keeled segments alternating with the teeth, and often split along the keel, usually with I-3 cilia between the segments. When fully developed these cilia are appendiculate, i. e., bear short transverse appendages at the articulations; the cilia are sometimes rudimentary and in a few species the inner peristome is adherent 
to the outer. Growing on the ground, rocks and walls, rarely on wood of any sort. This is a very large and difficult genus.

The border of ten varies on the same leaf. Lower leaves of Bryum are usually shorter and broader than the upper leaves and always have a shorter costa. The inner comal leaves are usually larger and narrower than the general run of leaves on the plant. The border of a Bryum leaf is usually most distinct near the base and least distinct near the apex. In using the key, select leaves in the lower part of the upper third of the leafy portion of the stem and look for border in the upper third of the leaf. The margin of the leaves is frequently strongly recurved and gives the appearance of a margin whether a margin be really present or not. To make sure, the margin must be flattened out by manipulation with needles and pressure on the cover-glass. It may even be necessary to use scissors.

Some of the species vary in the characters used in the key, hence these species have to be included under more than one of the headings.

Height as used in keys and descriptions applies to the gametophyte only. The leaves in Bryum are markedly smaller than in Mnium, and the leaf cells are much more elongated. The capsules are usually more slender, longer necked and more pendent.

Pohlia (Webera of the L. \& J. Manual) is so much like Bryum that a word of warning may not be out of place here. The leaf cells in Pohlia are much longer than in Bryum. B. capillare is frequently mistaken for Mnium because of its short leaf cells.

KEY

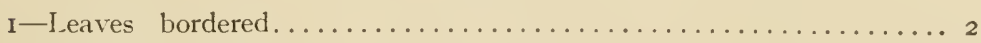

Leaves not bordered, at least in the upper half ............ 7

2-Costa plainly vanishing below apex. (See also B. capillare).cyclophyllum

Costa percurrent or excurrent in some of the leaves........... 3

3-Teeth of peristome with oblique or vertical lines connecting the transverse articulations; inner peristome without cilia, somewhat adherent to the outer..........................

Teeth of peristome without unusual markings; all rare; cilia lacking or rudimentary, not appendiculate; mouth of capsule oblique.

uliginosum

Teeth of peristome without unusual markings; cilia 2-4, nearly as long as the segments, usually appendiculate............ 4 
4-Costa long excurrent; dioicous. (See B. capillare).........caespiticium

Costa long excurrent; synoicous................ intermedium

Costa percurrent or shortly excurrent................ 5

5 -Leaves decurrent............................ 6

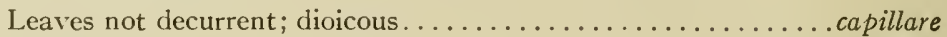

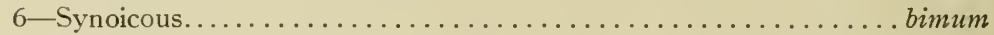

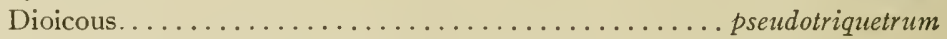

7 - Costa plainly vanishing below apex (plants silvery and shining when

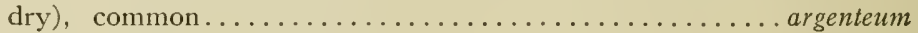

Costa excurrent or percurrent.................... 8

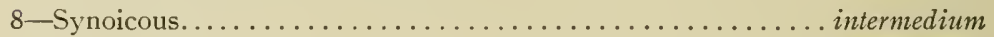

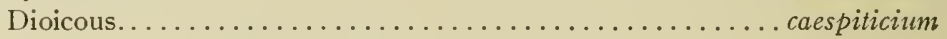

\section{SUBGENUS I. CLADODIUM}

Inner peristome more or less adherent to the outer, with cilia lacking or rudimentary; when present the cilia are not appendiculate.

\section{Section 1. Ptychostomum}

Outer teeth with irregular oblique or vertical lines on the inner surface, connecting the transverse articulations of the lower portion of the teeth.

B. pendulum (Hornsch.) Schimp. "About roots of trees in open woods, near Closter, N. J.," Musc. App. I96. Springsummer.

\section{Section 2. Eucladodium}

Differing from Section $\mathrm{I}$ in the lack of oblique or vertical markings between the articulations of the teeth. The species of this section are rare and seldom collected.

B. uliginosum (Bruch) B. \& S. Yonkers, E. C. Howe Bx!; Hoboken, N. J., Austin, Bx!; wet rocks near Haverstraw (N. Y.), Musc. App. I9I. Late summer.

\section{SUBGENUS 2. EUBRYUM}

Peristome perfect, inner free from outer, cilia nearly or quite as long as segments, appendiculate. Spores smaller than in Cladodium.

\section{Section 1. Leucodontium}

Teeth of peristome pale yellow throughout, base of teeth scarcely thicker. (Though European authors emphasize the color of the teeth, I am unable to make use of it.) 
B. cyclophyllum (Schwaegr.) B. \& S. "About roots of trees subject to inundation in a swamp near Closter, N. J.," Musc. App. I92; Bronx Park, E. G. B., Bx!

\section{Section 2. Pseudotriquetra}

Plants robust (for the genus), with strongly decurrent leaves, which are rather sharply acuminate; costa usually excurrent, and leaf apex or excurrent costa serrate or toothed; peristome thickened and reddish at base. This last character is of ten obscure.

B. bimum Schreb. "Wet places, common," Musc. App. I94; "Wet rocks, Palisades, New Jersey," Musc. App. 195; frequent. Summer.

B. pseudotriquetrum (Hedw.) Schwaegr. "Moist rocks, very common in northern $\mathrm{N}$. J. and southern $\mathrm{N}$. Y.," Musc. App. 200; Palisades of N. J., Austin, Bx!

\section{Section 3. Caespitibryum}

Plants usually smaller than in the last section; leaves not decurrent, long acuminate, with costa excurrent. Peristome as in the last section.

B. caespiticium L. The most common of all our species, being found in rather dry soil in all kinds of situations, and on rocks and walls. Spring-summer.

B. intermedium Brid. Frequent. Spring-summer.

\section{Section 4}

The peristome in the following species has the characteristics of the two preceding sections. In this section I have put species which did not fit into any of the others.

B. capillare L. A species likely to be mistaken for a Mnium, as it is Mnium-like in habit and in shape and structure of leaves, but the capsule is typically that of Bryum, with neck one-half as long as the rest of the capsule, or longer. "Shaded banks and rocks, common but sterile in N. J.," Musc. App. I99; Eastchester and Bronx Park, E. G. B., Bx! 
B. argenteum L. A small species, growing everywhere; usually in dense mats. It is especially fond of dry compact soil in sandy fields and waste places. It grows abundantly in paths and between the bricks of sidewalks in towns and cities. When full grown it is a bright silvery gray. Autumn.

\section{RHODOBRYUM (Schimp.) Hampe}

Nearly always dioicous. Very large plants, the largest and showiest of all this family. The stems spring from stolons, and are nearly leafless except at the summit, where the very large leaves form a rosette. Under favorable circumstances large mats are formed on old rotten logs or at the base of trees in rich peaty soil.

R. roseum (Weis.) Limpr. "On decayed wood, on the ground about the roots of trees and on moist rocks, frequent," Musc. App. 203. Apparently orcasional about the city, Closter, Yonkers, Bronx Park; Todt Hill, S. Id.

\section{Subfamily 2. Mnieae}

Plants usually larger than in Subfamily I, with larger broader leaves. Leaf cells nearly as broad as long. Plants rarely branching by innovations below the "flowers," frequently stoloniferous, $i$. e., with prostrate or creeping sterile shoots that root at their tips. Capsules usually without appreciable neck; stomata usually immersed or partially so, rarely completely superficial.

\section{MNIUM (Dill.) L. (Plate VII. Fig. 2.)}

Plants usually large with large leaves, which are broadly oblong, or obovate to lingulate, the lower nearly always shorter and more rounded than the upper, usually with a strong distinct border which is often strongly toothed. Costa usually percurrent or nearly so, sometimes shortly excurrent. Leaf cells rounded-hexagonal to quadrate-hexagonal, somewhat larger and elongated at base, not papillose. Calyptra small, cucullate. Capsules oblong-cylindric to ovoid, pendent, not pyriform; operculum mammillate to rostrate. Peristome perfect; cilia of ten nodose but not appendiculate. 
Nearly all the species are large handsome mosses, easily distinguished even when sterile. Moist shaded ground rich in humus, or much decayed wood in moist shaded places, are favorite habitats of the genus.

Rhodobryum roseum is the only plant likely to be confused with Mnium.

\section{KEY}

I-Leaves not bordered or border very slight................ 2

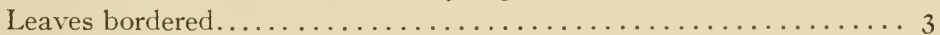

2-Plants large, leaves entire or very slightly serrate by projecting cells; leaf cells twice as long as broad, marginal cells linear....cinclidioides

Plants much smaller, leaves usually serrate; leaf cells isodiametric (i. e., as broad as long).......................... stellare

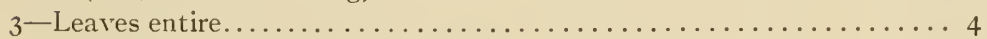

Leaves serrate, with single teeth...................... 5

Leaves serrate, with teeth in pairs................... 8

4-Leaves costate to apex........................ punctatum

Costa vanishing below apex...............punctatum var. elatum

5-Leaves serrate to base or nearly so; capsules clustered...........6 6

Leaves serrate in the upper $1 / 2$ or $2 / 3$ only.............. cuspidatum

6-Teeth of leaf margins of $2-5$ cells (except affine rugicum); operculum mammillate or apiculate.......................... 7

Teeth of leaf margins very short; operculum strongly beaked. .rostratum 7-Dioicous; many marginal teeth of more than two cells..........affine

Synoicous; marginal teeth shorter, few of more than two cells.... medium

8 -Costa vanishing below apex......................... hornum

Costa reaching apex in upper leaves.................. 9

9-Costa toothed on the back; dioicous .................. I I

Costa not toothed on the back; synoicous.................

Io-Capsules sometimes clustered; peristome forming a conspicuous redbrown band around the mouth of the deoperculate capsule.spinulosum

Capsules not clustered; peristome yellowish to brownish....marginatum II - Leaf cells hexagonal, small, about ${ }_{12}-\mathrm{I} 5 \mu \ldots \ldots \ldots \ldots$ orthorrhynchum Leaf cells rounded at the corners, about $20 \mu \ldots \ldots \ldots \ldots$. lycopodioides

A. SerrataE. Leaves bordered, serrate with single teeth.

M. affine Bland. Much less frequent than the variety. Several localities on Staten Island, E. G. B. (Bx)!; "Common," Musc. App. 205; Bedford, E. G. B., Bx!

Var. ciliare (Grev.) CM. Frequent in damp shaded places. May. 
Var. rugicum B. \& S. Lawrence and Oyster Bay, L. Id!!, Bulls Head, S. Id.!!; Bronx Park, R. S. W. \& E. G. B., Bx!

M. cuspidatum (L.) Leyss. (M. sylnaticum Lindb.). Conmon in damp shaded places. May.

M. medium B. \& S. "? Wet rocks, Little Falls, N. J.," Musc. App. 206.

M. rostratum Schrad. "Wet rocks, Palisades and northern N. J. \& southern N. Y., rare," Musc. App. 207 ; Jamaica (24807)!! Orient, Latham, on L.. Id.; Princes Bay, S. Id. \& Bronx Park, E. G. B., Bx!

\section{B. BiserRAtAE. Leaves margined, serrate with double teeth.}

M. hornum L. Wet shaded places, especially along streams and around springs; common. April.

M. lycopodioides (Hook.) Schwaegr. "On shaded rocks, Northern N. J.; also on decayed logs in Herkimer Co., N. Y.," Musc. App. 208.

M. marginatum (Dicks.) P. B. "Shaded banks and crevices of rocks, Palisades and northern N. J.; scarce," Musc. App. 210.

M. orthorhynchum B. \& S. Wallingford, Bry. Ct.

M. riparium Mitt. Rockland Co., N. Y. and Bergen Co., N. J., Austin. According to Mrs. Britton Austin's specimens are not this species.

M. spinulosum B. \& S. "On rocks in a ravine at Godwinville, N. J., also on wooded banks, Rockland Co., N. Y.," Musc. App. 209; Darien, Bry. Ct.

\section{Leaves bordered (slightly so in $M$. cinclidioides), entire.}

M. punctatum L. Not reported from L. Id., frequent elsewhere; banks of rivulets. Early spring.

Var. elatum Schimp. Common in swampy places.

M. cinclidioides (Blytt.) Hueben. "Swamps and wet woods, Palisades (frequent), northern N. J. and southern N. Y.," Musc. App. 2 I 4 \& 2 I5. $_{5}$ 
D. Leaies not bordered, serrate.

M. stellare Reich. "On shaded cliffs and banks and about the roots of trees in swamps, rather frequent but rarely fertile," Musc. App. 216; Palisades, N. Y., E. G. B., Bx!

\section{Subgroup. 2. Pleurocarpae}

Sporophyte from a lateral bud on a branching prostrate or ascending plant; occasionally the plants are erect, as in Climacium. Peristome for the most part almost like that in the Bryaceae, except that in the Hypnaceae and some closely allied genera, the basal segments of the peristome teeth are ornamented by very fine transverse lines.

\section{FAMILy 21. LESKEACEAE}

Mosses of varying habit and size, growing on shaded earth, stones, trunks of trees, or decayed wood, usually lusterless; main stems creeping with ascending or erect secondary stems. In Thuidium the stems are regularly pinnately branched and ascending, having somewhat the appearance of miniature ferns. Stem leaves often very different from the branch leaves, both strongly costate in most species, costa never excurrent; leaf cells rarely more than three times as long as broad, of ten less, mostly papillose, papillae of ten very large; leaf cells of the basal portion of the leaves more elongated and less strongly papillose, often smooth. Paraphyllia present in most species, varying in form but mostly slender and branched. Seta long, smooth, twisted when dry. Capsule erect and symmetric in most of our species, except in the genus Thuidium. Thuidium also has the perfect hypnaceous peristome, but most of the other genera illustrate well the degeneracy of the peristome in erect capsules, in which the cilia are usually vestigial or lacking and the segments often very narrow, or, in some cases, imperfect.

\section{Key to the Genera}

I-Plants regularly and pinnately branching, capsules usually curved with perfect peristomes. (See also Claopodium)......... Thuidium

Secondary stems usually ascending from prostrate main stems, not regularly pinnate; peristomes usually imperfect, and capsules

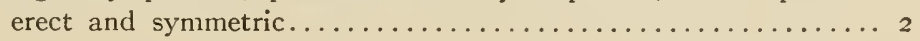


2-Plants bluish or glaucous green (scarcely so in $T$. hirtella); leaf papillae very large, often lobed or branched; paraphyllia lacking. . 3

Not bluish or glaucous green; papillae smaller, or rarely lacking; paraphyllia present except in Anomodon and part of Leskea......4 4

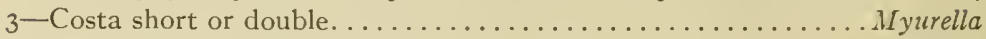

Costa single, usually reaching the middle of the leaf.......... Thelia 4-Costa double or short or almost lacking. (See also Leskea denticu-

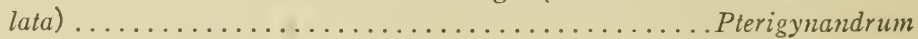

Costa single, strong. ...................... 5

5 - $q$ buds and sporophytes borne on secondary stems; paraphyllia

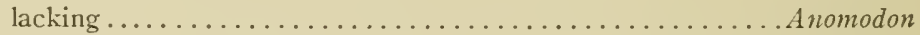

\& buds and sporophytes borne on primary stems; paraphyllia present

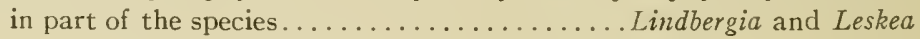

\section{THUIDIUM B. \& S. (Plate VIII.)}

The Thuidia are widely distributed and have been noted by every lover of out-of-door life because of their delicate and beautiful fern-like form. The branches are given off very regularly like the pinnae of a fern, and the branches themselves often give off branchlets as regularly as the pinna of a fern is divided into pinnules.

The stems bear paraphyllia of various sizes and shapes, but all are more or less linear or filamentose, often divided and branched, but not leaf-like. There is often considerable difference between the stem and branch leaves in shape and size. The ovate-triangular stem leaves are usually papillose on both surfaces, unicostate, the costa passing the middle. The median leaf cells vary from roundish quadrate-hexagonal to rhombicoblong; in two species linear-rhomboidal. The capsules, on smooth pedicels, are annulate, more or less curved. The opercula vary from conic to rostrate; the peristomes are well developed; the endostomial band $1 / 3$ the length of the teeth, with segments and cilia.

\section{KEY}

I-Apical cells of branch leaves crowned with 2-4 papillae; median cells quadrate-hexagonal to oblong-rhomboidal................ 2

Apical cells of branch leaves with a single terminal papilla; median cells as in 2. Paraphyllia numerous, branched............. 7

Apical cells of branch leaves not papillose; median leaf cells linearrhomboidal. Paraphyllia long-linear or filamentose.... paludosum

2-Paraphyllia few, small, linear-oblong, $2-6$ cells long; branch leaves subcrispate-incurved when dry ...................... 3

Paraphyllia numerous, more or less branched $\ldots \ldots \ldots \ldots \ldots \ldots .4$ 
3-Plants very small, I-2 cm.; stem and branches filiform, branches papillose; growing in thin mats on limestone rocks......pygmaeum

Plants snall, 2-4 cm.; loosely caespitcse; branches smooth; growing on the ground and rotten wood...............minutulum 4-Stems closely pinnately branched, branches terete-foliate when dry . . 5

Stems loosely pinnately or bipinnately branched...........6 6 5-Plants soft; leaf cells with ${ }^{2-5}$ small papillae on each surface.... scitum

Plants rigid; leaf cells with a single papilla on each surface..... abietinum 6-Pinnate or bipinnate; stem leaves spreading-recurved when moist, costa subpercurrent; perichaetial leaves not ciliate....... recognitum

Bipinnate or tripinnate; stem leaves erect spreading when moist, costate to $4 / 5$; perichaetial leaves ciliate........... delicatulum

Bipinnate; stem leaves with a hyaline filiform acumination; peri-

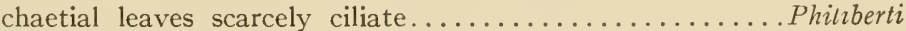

7-Stem leaves roundish ovate, abruptly linear-oblong-acuminate, margins erose-serrate..................... virginianum

Stem leaves broadly ovate, long and narrowly acuminate, margins crenulate-serrulate or entire...............microphyllum

T. abietinum (L.) B. \& S. "On dry limestone ridges, Sussex Co., N. J., very abundant," Musc. App. 304; Yonkers, E. C. Howe, Bx!

T. delicatulum (L.) Mitt. On shaded rocks and banks; common. Winter.

T. microphyllum (Sw.) Best. "Woodbridge," Bry. Ct.

T. minutulum (Hedw.) B. \& S. "On decayed wood in swamps; common," Musc. App. 297; Pleasant Plains, Court House and Woods of Arden, Mosses of S. Id.; Closter, Austin, and New Brunswick, N. J.; Vail. Autumn.

T. paludosum (Sull.) Rau \& Hervey. Frequent in wooded swamps. Winter.

Var. elodioides (R. \& C.) Best. Wet meadow, Oyster Bay, L. Id.!!

T. Philiberti Limpr. "Base of small trees in wet places, Stockton, N. J." G. N. Best, Bx!

T. pygmaeum B. \& S. Closter, N. J., Austin, Bx!

T. recognitum (Hedw.) Lindb. This is reported from Richmond Hill and Northport, L. Id., from S. Id. and from N. J., but the identification of the specimens is uncertain. 
T. scitum (Beauv.) Aust. "On base of trees near Closter, N. J.," Musc. App. 300; Flushing!! and Orient, L. Id.; New Dorp, Todt Hill and Tottenville, S. Id., E. G. B., Bx!; Palisades, state line, N. Y. \& N. J., E. G. B., Bx! Autumn-winter.

Var. aestivale (Au'st.) Best. "On roots of trees, N. J, \& N. Y.; frequent," Musc. App. 30r.

T. Virginianum (Brid.) Lindb. On dry sterile ground in open woods, also about the bases of trees; frequent. Spring.

\section{CLAOPODIUM R. \& C.}

Plants variable in size. Stems creeping, radiculose, stoloniferous; stem leaves triangular to broadly ovate, long and narrowly acuminate, margins plane, dentate-serrate, costa translucent; leaf cells small, round-hexagonal to rhombic, thickenedpapillate on both surfaces; dioicous. Seta rough; capsule horizontal; annulus compound; cilia $\mathrm{I}-3$; operculum long-conic to conic-rostrate. Differs from Thuidium in the absence of filamentose paraphyllia and from Anomodon in the curved capsules.

C. pellucinerve (Mitt.) Best. Noroton, Ct., Mrs. J. D. Lowe. Fide Dr. Best, Brỵologist 6:39. 1903.

\section{LESKEA Hedw.}

Plants small to medium-sized, growing in tufts about the base of trees, on bark of lower trunk, on rotten wood, more rarely on stones or soil in damp shady places. Stems prostrate, usually radiculose, sometimes paraphyllose, pinnately to fasciculately branched, rarely stoloniferous; leaves of ten papillose, ovate to ovate-lanceolate, acute, acuminate or obtuse, usually unicostate, sometimes shortly bicostate, nearly or quite entire (excl. L. denticulata); leaf cells somewhat uniform, median quadrate-hexagonal to oval-obiong, rarely elongated; setae smooth; capsules usually straight and erect, sometimes curved, oval to subcylindric, annulate; teeth well developed; segments linear, of ten kecled and cleft; cilia usually none or rudimentary; opercula mammillate to long-conic, rarely rostellate; calyptra cucullate, smooth. 


\section{KEY}

I-Leaves papillose, costate; median cells usually isodiametric; peristo nial teeth abruptly incurved from a bulging base when dry... Euleskea 2

Leaves smooth or nearly so, costate or ecostate; peristomial teeth erect

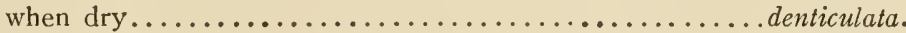

2-Leaves ovate-lanceolate, acute to acuminate, more than twice as long as

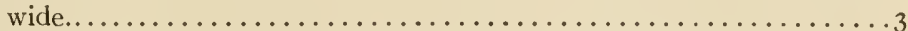

Leaves ovate, subacute to obtuse, less than twice as long as wide....... 3-Capsules straight (except var, paludosa); operculum short-conic

Capsules curved; operculum long-conic. 4-Leaves symmetric, biplicate, margins often revolute........gracilescens

Leaves asymmetric, not plicate, margins plane............ obscura

L. arenicola Best. Rosemont and New Lisbon, N. J., Best. Probably frequent.

L. denticulata Sull. "On dry rocks and roots of trees, always sterile in N. Y. and N. J.," Musc. App. 267; Orange, Bry. Ct.*

L. gracilescens Hedw. Byram, Stockton, \& Rosemont, N. J., Best; Toms River, N. J.!!, on shade trees in the street. Probably not rare about N. Y. City, but is little known.

L. obscura Ehrh. "On stones and roots of trees within the reach of floods; common," Musc. App. 270; Bronx Park, E. G. B. \& R. S. W., Bx!; Willow Brook, S. Id.!!; Yonkers, Howe, and Closter, N. J., Austin, Bx!

L. polycarpa Ehrh. Bronx Park and S. Id., E. G. B., Bx!; Closter, N. J., Austin, Bx!

\section{LINDBERGIA Kindb.}

Differs from Leskea in having peristome teeth papillose, inner peristome a short basal membrane without teeth or cilia.

L. Austinii (Sull.) Broth. (Leskea Austinii Sull.). "On stone fences, Sussex Co., N. J.," Musc. App. 268.

\section{PTERIGYNANDRUM Hedw.}

Somewhat resembles Leskea in general appearance and inhabits similar places, roots and bases of trees, damp stones, etc.

* Brotherus in "die Natürlichen Pfanzenfamilien" puts this in the Entodontaceae (Entodonteae) as Schwetschkeopsis denticulata (Sull.) Broth. 
It is distinguished from Leskea by the much shorter costa, which may be single and reach the middle of the leaf, or be shorter and double, or even almost wanting: leaves much narrowed at base, of ten obovate, very concave; inner peristome of 16 rather short linear to irregular segments, without basal membranes or cilia.

P. filiforme (Timm.) Hedw. "On rocks and roots of trees, Palisades, N. J.," Musc. App. 280.

\section{ANOMODON Hook \& Taylor. (Plate IX, Fig. I.)}

Much like Leskea in habit of growth but much larger and coarser (excl. A. rostratus and A. tristis), when fully developed growing in mats consisting of a network of nearly leafless primary stems growing close to the substratum and sending up secondary stems and branches in great numbers. The leaves described are those of the secondary stems and branches, those of the primary stems are usually quite different. The stems lack paraphyllia. The leaves are densely papillose on both sides and almost opaque, and have a single long, strong, pellucid costa (shorter in tristis); leaf cells irregularly hexagonal, a few in the median basal area usually elongated and pellucid. Capsules and peristome much as in Leskea but the former borne on the branches, the latter very brittle; inner peristome as a rule less developed than in Leskea. All our species are dioicous.

KEY

I-Secondary stems and branches slender, usually julaceous when dry.. 2

Secondary stems and branches coarse, scarcely julaceous........ 3

2-Leaves slenderly acuminate, ending in a hair point; plants growing in moist places at base of trees and about ledges........... rostratus

Leaves narrowly lingulate from an ovate base, obtuse to apiculate; plants growing on bark of trees as a rule..............tristis

3-Secondary stems much branched as a rule, many branches attenuate to flagelliform; some of the leaves apiculate and toothed at the

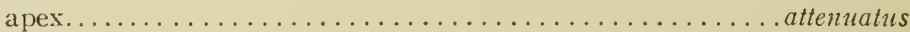

Secondary stems more sparingly branched, no attenuate branches... 4 4-Upper portion of leaves lingulate-lanceolate, conspicuously tapering to the apex, somewhat contorted and crisped when dry, often secund: plants usually growing on rocks............ viticulosus

Upper portion of leaves lingulate and of nearly equal breadth, not secund; plants nearly always growing on bark of trees, stumps or

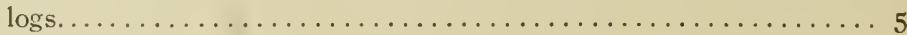


5-Leaves somewhat crisped when dry with points incurved, not decurrent, having large fimbriate-papillose auricles, often apiculate.

apiculatus

Leaves scarcely contorted when dry, somewhat irregularly appressed, decurrent, without auricles, not apiculate.............minor

A. apiculatus B. \& S. "Jordansville, N. Y.," Austin, Bx.!

A. attenuatus (Schreb.) Hueben. "About the roots of trees and on rocks, common," Musc. App. 274; New Lots, Jamaica, and Greenport on Long Id.; New Dorp, Bloodroot Valley and Tottenville on S. Id.; Williamsbridge, Bedford, East Chester and Yonkers, N. Y. Autumn-winter.

A. minor (P. B.) Fuern. "On roots of trees and on rocks, common," Musc. App. 275; Closter, N. J., 276 (as var. fragilis); New Lots (26295) and Jamaica (26294), Long Id., Brainerd; Bloodroot Valley, S. Id.!! Late autumn to winter.

A. rostratus (Hedw.) Schimp. About roots of trees, etc., in damp places, common. Autumn.

A. tristis (Cesat.) Sull. "On trees and rocks, common, always sterile," Musc. App. 273; New Dorp, S. Id., and Bronx Park, E. G. B., Bx!; Closter, N. J.,!! N. Am. Musc. Pl. I95.

A. viticulosus (L.) Hook and Taylor. "On limestone rocks, Sussex Co., N. J." Musc. App. 278.

\section{THELIA Sull. (Plate IX, Fig. 2.)}

Plants of this genus as a rule are easily recognized by the light color, very light to glaucous-green, and the rather short crowded julaceous stems from creeping primary stems. In depauperate or very young plants the branches are of ten scattered. Under the microscope the most striking thing is the enormous single papilla on the back of each leaf cell. The costa is usually single and extends about half the length of the leaf. Capsules ovoidcylindric, operculum beaked; outer peristome teeth conspicuously whitish, slender; inner of a well developed basal membrane with segments very rudimentary or none.

I-Growing on rather dry sandy soil, rarely on bases of trees...... Lescurii Growing on the base of trees, never on the ground............ 2

2-Plants distinctly glaucous; leaf papillae forked.............. asprella

Plants scarcely or not at all glaucous; papillae simple...........hirtella 
T. hirtella (Hedw.) Sull. Very common on bark of trees. Autumn.

T. asprella (Schimp.) Sull. Cold Spring (26126)!!; New Lots (26125) and Jamaica (26r24), Brainerd, L. Id.! "On roots of trees, old stumps and on stones in open woods, common," Musc. App. 263; Alpine, N. J., Jelliffe, Bx!; Yonkers, Howe, Bx! Early autumn.

T. Lescurii Sull. "On flat rocks, Palisades. On white sand about base of stunted oaks in Southern N. J.," Musc. App. 264; sandy soil, Orient, Latham, and Rockaway and Lynbrook on L. Id. Rarely fruiting. Also found in southern Ct.

MYURELLA B. \& S.

M. Careyana Sull. "Banks of ravines about Hohokus and in Mts. of N. J.," Musc. App. 265; Closter, N. J., Austin, Bx.!

M. julacea (Vill.) B. \& S. occurs in the Del. IVater Gap.

\section{FAMILX 22. HYPNACEAE}

Plants creeping in habit, forming mats of more or less closely interwoven stems and branches, growing mainly on soil and rotten wood, less frequently but commonly on stones and trunks of trees, a few aquatic.

Leares costate or ecostate, not papillose, except Bryhnia and Hylocomium species. Capsules on elongated setae more or less curred and unsymmetric except in the Climacieae, Entodonteae and a few anomalous mosses. Peristome usually perfect, the cilia of ten lacking in mosses with erect capsules, segments always keeled; teeth strongly articulate, marked at base between the articulations by characteristic fine transverse lines except in a few forms with erect capsules and degenerate peristomes. A very large family closely related to the Leskeaceae, from which it differs in the non-papillose (except Bryhnia) leaves and also usually in the longer leaf cells and unsymmetric cernuous capsules. The peristomes are very close to those of the Bryaceae except for the fine transverse lines on the peristome teeth. 
This family is a large and somewhat heterogeneous one and includes practically all the pleurocarpous mosses with elongated smooth leaf cells and well developed peristomes, $i$. e., having broad keeled segments and, usually, well developed cilia. Although the leaf cells are of ten short and broad, they are more or less rhomboidal or elongated-hexagonal in outline and in the middle of the leaf are never regularly oval, rounded, or quadrate.

The mosses of this family may be found in all kinds of habitats, and some individual species have a wide range of habitat.

The classification of this family is a matter upon which no two bryologists would be likely to agree. No single character can be relied upon as a basis of classification, and it is extremely difficult to select combinations of characters that will indicate relationships with any degree of accuracy. Many characters relied upon in the past are almost certainly very highly modified, if not actually produced, by habitat conditions. Short thickwalled leaf cells are so frequently çorrelated with a xerophytic habitat as to suggest a causal relation. There is almost certainly a relation between habitat and the curvature and direction assumed by the capsule, and between this last and the completeness of the peristome. These statements, of course, apply to mosses outside this family, but the difficulties in classification caused by these facts are particularly prominent here.

The following grouping into subfamilies is primarily based more on the structure and robustness of the costa and the presence or absence of central strand in the stems than in most of the older groupings. For exceptions to the characters indicated in this key see the descriptions of the subfamilies.

\section{Key to the Subfamilies of the Hypnaceae}

I-Costa strong and extending to the middle of the leaf or beycnd, nearly always single, (exceptions in Hylocomium and Campylium).. 3

Costa short and double or lacking. . . . . . . . . . . . . . 2

2-Capsules erect and symmetric, or nearly so; cilia of inner peristome

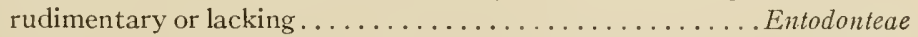

Capsules unsymmetric, more or less curved, usually cernuous.. Hypneae

3-Plants large, secondary stems stout and dendroid from creeping or

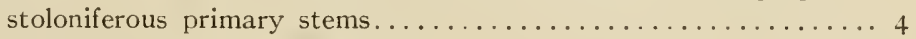

Plants smaller, scarcely dendroid................. 5 
4-Capsules erect and symmetric; peristome without cilia..... Climacieae

Capsules curved, cernuous; peristome perfect........... Porotricheae

5-Capsules ovoid, short, thick and unsymmetric, usually little contracted under the mouth when dry; stem and branch leaves often

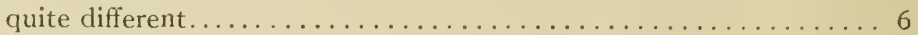

Capsules longer, arcuate-cylindric as a rule, usually more contracted under the mouth when dry................. mblystegieae

6 - Costa single and usually reaching well beyond middle of leaf; seta

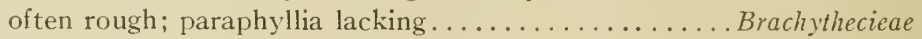

Costa frequently double, often short; paraphyllia large and abundant in many species; seta smooth ...................

\section{Subfamly Hylocomeae}

The characters of this subfamily are pretty well enumerated under Hylocomium. Its position is somewhat of a novelty as the usually double costa has caused it to be most frequently put with the Hypneae, yet the large and abundant paraphyllia of some of the species as well as gross appearance resemble the Thuidia, while the capsules are certainly more like the Brachythecieae than the Hypneae. The stems, moreover, possess a central strand.

\section{Key to Genera}

Leaves secund, strongly rugose; no paraphyllia ............ Rhytidium Leaves not secund nor rugose; paraphyllia very abundant in some species.

Hylocomium

\section{HYLOCOMIUM B. \& S.}

Large robust mosses growing in wide, loose patches, characteristically in cool moist woods (the name signifies "inhabitants of the wood"), of a various habit yet for the most part with a common facies that is more easily recognized than described. Some are complanately branched and regularly bi-pinnate after the manner of Thuidium, most are rather irregularly branched. A number of the species have the stems densely corered with large branched paraphyllia. Leaves usually large and strongly plicate to sulcate. Costa single and strong but never percurrent, or double and more or less well developed. This genus, Hygrohypnum, and Campylium contain species with the costa single and double or even wanting, yet the species of these genera that vary in the development of the costa and also in that of the central strand are often very closely related. This goes to show 
conclusively that no single character can be relied upon for the purpose of classification but that all characters must be taken in to consideration.

The leaf cells in this genus are narrowly linear, frequently papillose at the back of the leaf by the thickening of the angles of the cell walls as in Bryhnia, comparatively little differentiated at base and angles, usually somewhat shorter and broader and often colored. Our species are dioicous; capsules large, short, inclined and unsymmetric, much as in the Brachytheciae: peristome perfect with well-developed cilia.

\section{KEY}

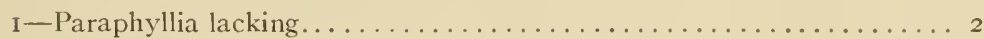

Paraphyllia present, usually very abundant............. 3

2-Stem leaves not plicate, strongly squarrose-recurved....... squarrosum

Stem leaves plicate, widely spreading but not recurved......triquetrum

3-Plants regularly and closely bi-tri-pinnate............ proliferum

Plants rather irregularly branched............... brevirostre

H. brevirostre (Ehrh.) B. \& S. "Deep shaded ravines and swamps. Sterile in N. J.," Musc. App. 448; Little Falls, N. J., Austin, $\mathrm{Bx}$ !

H. proliferum (L.) Lindb. (H. splendens B. \& S.). Rare. "Northport, Sanial," Flora L. Id. "On the ground in woods, northern N. J.," Musc. App. 447. Spring.

H. squarrosum (L.) B. \& S. Hamden, Bry. Ct.

H. triquetrum (L.) B. \& S. New Lots and Partegat (27226), Brainerd, and Northport, Sanial, on L. Id. "Common, sterile in N. J.," Musc. App. 449; Kreischersville, S. Id., Hollick and Britton, Bx!, "Four Corners," Mosses S. Id. Winter-spring.

\section{RHYTIDIUM (Sull.) Krindb.}

R. rugosum (L.) Kindb. Dry bluffs and ledges. Palisades, N. J., Austin, Bx.!; "Common, sterile," Musc. App. 450.

\section{Subfamily Brachythecieate}

Hypnaceous mosses differing but little in general appearance from many of the Hypneae, nearly always more or less glossy. The leaves are straight and imbricated when dry, occasionally 
loosely spreading, erect-open when moist. Very rarely falcate or secund except in B. vehutinum and its allies, of ten strongly plicate or sulcate, at least when dry, simply costate half way or more, leaf-cells linear-vermicular (except B. reflexum, B. digastrum and B. cyrtophyllum). Alar cells differentiated, of ten inflated and hyaline, sometimes quadrate and densely chlorophyllose.

Capsules brown to chestnut-brown, ovoid, short, cernuous and unsymmetric except in Homalotheciella and in B. oxycladon, and $B$. acuminatum and its allies, rarely or never plicate or strongly contracted under the mouth when dry; operculum conic, conic-apiculate or long-rostrate, seta often roughened with prominent papillae; peristome perfect except in species having erect capsules.

\section{Key to the Genera}

I-Operculum with very long, needle-like beak ............. 2

Operculum conic or at most with a very short beak.......... 3

2-Apices of branch leaves abruptly long-acuminate from a spoon-shaped base, apical cells not broader or shorter than the median. Cirriphyllum

Apices of branch leaves acute to obtusely-acute, with apical cells broader and shorter than the median (except E. serrulatum).

Eurhynchium

3-Leaves markedly papillose on the back with projections from the

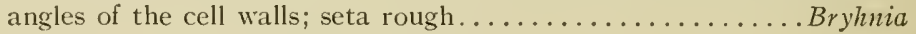

Leaves not papillose, seta rough or smooth............. 4 4-Leaves all elongated-lanceolate, very strongly sulcate with numerous folds; plants very glossy, golden green......... Camptothecium

Leaves broader, less strongly sulcate or even smooth, less glossy.... 5 5 5-Calyptra smooth; inner peristome free............ Brachythecium

Calyptra hairy; inner peristome adherent to teeth...... Homalotheciella

\section{BRACHYTHECIUM}

Plants mostly of medium size and typically hypnaceous habit, very rarely pinnately branching with any degree of regularity. Branch leaves acute to acuminate, never obtuse, usually somewhat concave and of ten plicate or sulcate, costate to above the middle, median leaf cells sinuous-linear to linear-rhomboidal (broader and shorter in B. reflexum, B. digastrum and in some leaves of B. cyrtophyllum), basal cells broader and shorter, alar quadrate, rarely inflated and hyaline. 
Stem leaves notably different in most species, larger and proportionately broader, of ten more slenderly acuminate and less strongly serrate; seta smooth to very rough, twisted to the right, capsules short-ovoid to oblong-ovoid, cernuous-arcuate and 2-4: I (cylindric in B. oxycladon and nearly erect and symmetric in $B$. acuminatum and $B$. cyrtophyllum), slightly contracted under the mouth when dry and empty, operculum conic to short rostrate; peristome characteristically hypnaceous and perfect except in the species with erect capsules. When in fruit this genus is easily recognized in most cases by the short, thick, dark-colored capsules which are usually unsymmetric and horizontal; spores almost without exception maturing in late autumn or early winter.

The grouping of species given below is a little different from that given in my monograph of the genus, in Vol. VI of the Memoirs of the Torrey Botanical Club, but represents opinions based on a great deal of additional study.

(I) The Salebrosum group consisting of $B$. salebrosum, $B$. flexicaule, B. acutum, B. campestre, B. oxycladon, and B. digastrum.

This group is characterized by smooth seta (except B. campestre), leaves plicate or sulcate when dry (except B. acutum), slenderly acuminate, concave and excavate at basal angles with the margins turned back parallel to the plane of the leaf (or reflexed in the ordinary descriptive language) in the lower portion; basal cells broader and shorter, quadrate alar cells numerous, hyaline or slightly chlorophyllose, stem-leaves ovate-lanceolate; annulus poorly developed, fairly well developed in $B$. acutum.

(2) The Rutabulum group including B. rutabulum, B. rivulare, and $B$. Starkei,, characterized by rough setae, well-developed annulus, ovate-deltoid stem leaves, all leaves less concave and alar cells less numerous, except in B. rivulare.

(3) The Acuminatum group resembling the salebrosum group in gametophyte characters but with nearly erect symmetric capsules and peristomes without cilia, consisting of $B$. acuminatum, B. cyrtophyllum and some southern species.

(4) The Plumosum group including $B$. plumosum and $B$. populeum, characterized by rough setae and densely chlorophyllose quadrate alar cells. 
(5) The Velutinum group including B. velutinum, B. erythrorrhizon and number of western species, characterized by small size and in our species by somewhat secund leaves.

KEY

I-Costa percurrent or nearly so................... populeum

Costa extending $1 / 2-2 / 3$ the length of the leaf $\ldots \ldots \ldots \ldots \ldots \ldots \ldots$

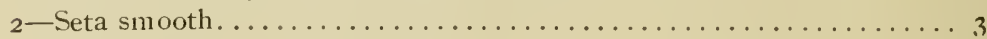

Seta rough above, smooth below.................... 9

Seta rough throughout.........................

3-Capsules erect and symmetric or nearly so, cilia of peristome rudimentary or lacking. ..................... 4

Capsules more or less cernuous and inclined, unsymmetric, cilia

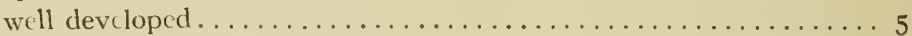

4-Plants very slender, leaves rarely more than $0.7 \mathrm{~mm}$. long.cyrtophyllum

Plants with the facies and size of $B$. oxycladon; leaves I-I.6 nm.

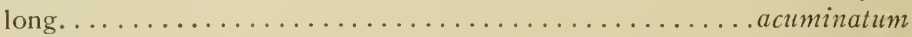

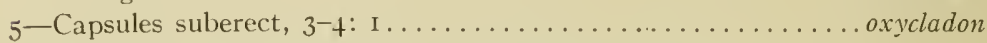

Capsules strongly inclined, and unsymmetric, $2-3:$ I ......... 6

6-Leaves not plicate or striate; stem leaves gradually narrowed from

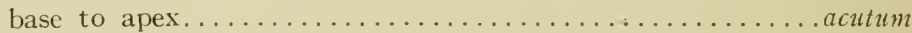

Leaves plicate or striate....................... 7

7 -Stem leaves lanceclate, $0.6 \mathrm{~mm}$. broad at base, gradually and evenly

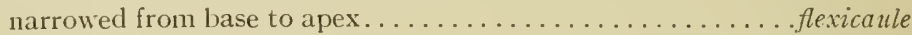

Stem leaves ovate, at least I mm. broad at base, more abruptly narrowed to a slender acumination. . . . . . . . . . . . . . 8

8-Sten leaves ovate-lanceolate, $2-2.5$ by $0.8-$ I. I $1 \mathrm{~mm}$, median leaf cells $10: 1 \ldots \ldots \ldots \ldots \ldots \ldots \ldots \ldots \ldots \ldots \ldots \ldots \ldots \ldots \ldots \ldots \ldots \ldots \ldots$ salebrosum

Stem leaves triangular-ovate, I.2-0.8 mm., median cells 4-6: I . digastrum 9-Leaves plicate, long acuminate, branch leaves strongly serrate. .campestre

Leaves not plicate, shorter-acuminate branch leaves entire or serrate.

plumosum

Io-Secondary stems often dendroid, stem leaves ovate and very shortpointed with enlarged and inflated alar cells............ rivulare

Not dendroid, stem leaves slenderly acuminate............ I I I I-Slender; leaves somewhat secund, in most American plants, stem

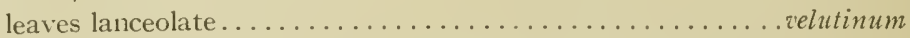

Robust; leaves not secund, stem leaves ovate to triangular-ovate.... I2 I2-Complanate-foliate like a Plagiothecium; leaves cordate-triangular and strongly and widely decurrent; cilia of inner peristome ap-

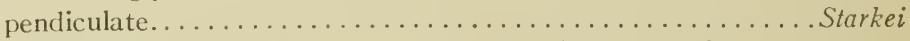

Not flattened; leaves ovate and less strongly decurrent; cilia not ap-

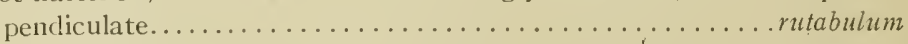

B. acuminatum (Hedw.) Kindb. "Centreport, Sanial," Flora L. Id.; Grant City, S. Id., E. G. B., Bx!; Closter, N. J., Austin, Bx!; Yonkers, Southworth, Bx! Autumn. 
B. acutum (Mitt.) Sull. "On the ground in swamps near Closter, N. J.," Musc. App. 3I6; Noroton, Ct., Mrs. J. D. Lowe!!; Valley Stream and Flushing (N. Am. Musci Pl. 2I3), L. Id.!! On rotten wood in swamps; autumn-winter.

B. campestre B. \& S. "On the ground in woods and under shrubbery in yards and gardens, Closter and northern N. J. and southern N. Y.," Musc. App. 3I4 \& 3I5. Probably frequent but scarcely to be distinguished when sterile. Autumnwinter.

B. cyrtophyllum Kindb. "About roots of trees and on stone fences along dusty highways," Musc. App. 3II, as B. acuminatum setosum. Undoubtedly from N. J.

B. digastrum C. M. \& Kindb. I have this from Kingston, N. Y., coll. M. E. Williams, and it undoubtedly occurs near N. I. City but has not thus far been recognized.

B. flexicaule R. \& C. Jamaica, L. Id.!! A subspecies of B. salebrosum.

(B. Noveboracense Grout from Valley Stream L. Id. is apparently a freak form of $B$. rutabulum or a hybrid between this and B. rivulare.)

B. oxycladon (Brid.) J. \& S. Damp soil and rocks. Frequent. Autumn-winter.

Var. dentatum (L. \& J.) Grout. Bloodroot Valley and Moravian Cemetery, S. Id.!!; Bronx Park, E. G. B.!!

B. plumosum (Sw.) B. \& S. Common on wet ground in swamps and on wet stones in and around streams and swamps. Autumn.

B. populeum (Hedw.) B. \& S. L'sually on rocks. Jamaica and Forest Park!!, Flatbush, Brainerd (28248), Brooklyn, Capt. Pike, Bx!, from L. Id.; New Dorp and Princes Bay, S. Id., E. G. B., Bx!; Yonkers, Howe, Bx!; "Same as last," Musc. App. 328 , that is to say "Common."

B. rivulare B. \& S. Common in brooks and pools and on wet ground and stones. Early autumn. 
B. rutabulum B. \& S. Common on ground and stones in wet or swampy places. Early winter. A variety approaching B. rivulare from S. Id. was issued as No. $42 \mathrm{I}, \mathrm{N}$. Am. Musci Pl.

Var. turgescens Limpr. Swamp, New Dorp, S. Id.!!

B. salebrosum (Hoffm.) B. \& S. Common, occurring on all sorts of substrata in rather damp places. Autumn-winter.

B. Starkei (Brid.) B. \& S. "Greenwood Mts. and Delaware Water Gap, N. J.," Musc. App. 323. "Darien, Mrs. J. D. Lowe," Bry. Ct.

B. velutinum (L.) B. \& S. On soil and stones, Orient, Latham, Prospect Park!!, and New Lots, Brainerd (260I4), on L. Id.; Closter, N. J., Austin!!; Clifton, N. J., Nash, Bx!

\section{BRYHNIA Kaurin}

Closely related to Brachythecium, but distinguished by shorter leaf cells (4-6: I), papillose at the angles by the projecting cell walls. The papillae are sometimes wanting in $B$. Novae-Angliae which leads M. Cardot to refuse this group generic rank.

KEY

Branch leares acute to short acuminate, apex twisted........ Novae-4ngliae Branch leares longer acuminate, apex not twisted.......... graminicolor

B. Novae-Angliae (Sull. \& Lesq.) Grout. (Hypnum NoraeAngliae Sull. \& Lesq.) Common on soil in swamps. Winter.

B. graminicolor (Brid.) Grout. "On banks of deep shaded rarines, common but rarely fertile," Musc. App. 33t; Egbertville, S. Id., E. G. B., Bx!; "Bath, Brainerd," Flora L. Id.; Canaan, Ct., Nichols, Bx!

CAMPTOTHECIUM B. \& S.

Plants closely allied to Brachythecium but for the most part distinct to the casual observer by reason of the bright golden or yellowish green silky luster and strongly plicate leaves, which are usually slender and have as a rule narrower leaf cells; seta rough or smooth. Our only species is:

C. nitens (Schreb.) Schimp "Peat bogs, near Sparta, N. J." musc. App. 307. Should be found nearer in cool bogs. 


\section{CIRRIPHYLLUM Grout}

Robust glossy mosses resembling Eurhynchium in the longbeaked opercula and other capsule characters, but resembling Brachythecium in their general leaf characters; leaves imbricate, very concave, spoon-shaped, of ten cucullate at the apex, abruptly drawn out into a long-filiform acumination, costate to the middle or beyond. Branches julaceous, usually turgid in appearance, due to the concavity of the imbricated leaves.

The species I have included here have usually been referred to Eurhynchium, but are so distinct in leaf form and structure that they are best treated separately.

C. Boscii (Schwaegr.) Grout (Hypmım Boscii Schwaegr.). Common on soil almost everywhere, especially in shaded grassy places but of ten depauperate and difficult to recognize. Autumn.

C. piliferum (Schreb.) Grout. Closter, N. J., Austin, Bx.! "On ground about roots of trees and on old logs in swampy places, N. J.," Musc. App. 336.

\section{EURHYNCHIUM B. \& S. (Plate X.)}

Resembling Brachythecium in general appearance; leaves costate to the middle or beyond, apical cells of branch leaves much broader and shorter than the median in some species, in others as long or longer. Stem leaves acute to long and slenderly acuminate; sporophyte as in Brachythecium, except for the long-beaked operculum, the beak being $1 / 3-1 / 2$ the length of the rest of the capsule.

The meaning and origin of the fantastic needle-like beak on the operculum in this and many other species of mosses, notably Dicranum, is a great puzzle. That it can be of any use so as to be favored by natural selection seems improbable. The only possible utility that I can imagine is that it serves to aid in dehiscence, causing the operculum to be knocked off more readily. As every collector knows, it is rather a difficult matter to find matured capsules of these long-beaked species in good condition and keep them so in the herbarium. One year I collected E. rusciforme on August I 5 in excellent condition, but apparently immature. When I collected for my North American 
Musci Pleurocarpi, I collected three weeks later and most of the opercula had fallen.

\section{KEY}

1-Apical cells of branch leaves oblong-rhomboidal to circular....... 2 Apical cells of branch leaves not materially different from the median cells.................................. serrulatum 2-Aquatic or subaquatic.............................

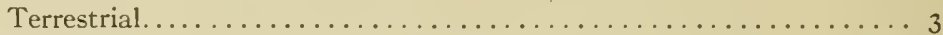

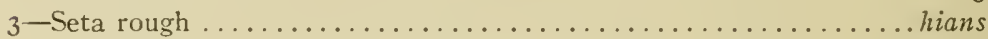

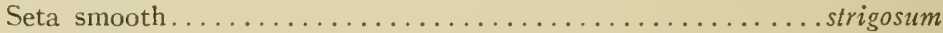

E. hians (Hedw.) J. \& S. Common on sandy soil especially in woods, but mostly sterile. Late autumn.

E. rusciforme (Neck.) Milde. "On rocks in rapid streams, common," Musc. App. 347. Closter, N. J., Bx!. near Northvale, N. J.!!; Princes Bay, S. Id., E. G. B., Bx!; Yonkers, Howe, Bx!; Palisades, N. Y., R. S. IV. \& E. G. B., Bx! August.

E. serrulatum (Hedw.) Kindb. Common on shaded soil, especially at base of trees. Sept.-Oct.

E. strigosum (Hoffm.) B. \& S. var. robustum Roell. "On banks in woods, common," Musc. App. 332. Not common according to $\mathrm{my}$ experience. Ridgewood, New Utrecht, Northport, Orient, on L. Id.; S. Id., Palisades, East Chester, Bronxville, E. G. B., Bx!; Yonkers, Howe.

Var. praecox (Hedw.) Husnot. New Utrecht and New Lots, Brainerd (H. S.)!; Prospect Park!! and Cold Spring!!; all from L. Id. "On shaded banks, common," Musc. App. 333 (as E. diversifolium); Egbertville and New Dorp, S. Id., E. G. B., Bx!; Hampton Court, Richmond, S. Id.!!

Var. scabrisetum Grout. Type from Palisades, N. J., also from Byram, N. J., Best.

\section{HOMALOTHECIELLA Cardot.}

Homalotheciella differs from Euhomalothecium Card. in its small size and concave nonplicate leaves. From Brachythecium it differs in the hairy calyptra and imperfect peristome. The plants have almost the appearance of a Pylaisia. The resemblance is all the more striking because the segments of the 
endostome adhere to the teeth as in Pylaisia intricata (Hedw.) R. \& C. One cannot help wondering if the similarity between Pylaisia, Platygyrium and this species is not due to the fact of their having a similar habitat. May it not be that their approach in capsule to Leskea, Lencodon, Anomodon, etc., is due to the same cause?

H. subcapillata (Hedw.) Card. (Homalothecium subcapillatum Sull.). "On trees, common," Musc. App. 295; Palisades, N. J., Austin, Bx!

\section{Subfamily Climaceae}

Characterized by the dendroid habit, strongly costate leaves, erect symmetric capsules and well developed peristome, lacking both cilia and the fine transverse markings on the base of the peristome. We have but one genus.

CLIMACIUM W'eb. \& Mohr.

Large handsome mosses with a tree-like habit of growth from underground creeping stems. Sometimes prostrate, or floating in very wet places. Stem and branches bearing paraphyllia. The leaves are all somewhat decurrent but vary greatly in shape and structure. The leaves of the main upright stems are very large, thin, with little chlorophyll, closely imbricated and clasping. Branch leaves smaller, of a different shape and texture, chlorophyllose. All our species are dioicous. The seta is long and smooth, twisted to the right when dry. Calyptra split on one side, long, reaching to the base of the capsule. Capsule erect, cylindric; operculum conic-rostrate with the beak often oblique; annulus none; peristome double; teeth linear-lanceolate, very long, closely articulate, minutely papillose; segments as long as the teeth, keeled, split between the articulations, often split to the apex when old, united at the base into a continuous narrow basal membrane, minutely papillose.

Mosses of swampy woods and fields; fruiting with comparative infrequency. The systenatic position of this genus is as yet doubtful. It certainly does not belong in the Entodonteae, where it has previously been placed. 


\section{KEY}

I-Capsules 3 to 4 times as long as broad; median leaf cells Io times as

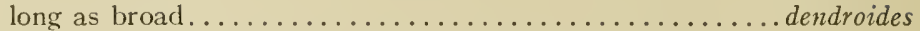

Capsules $5-6: \mathbf{I}$; median leaf cells not more than $7: 1 \ldots \ldots \ldots \ldots 2$ 2-Plants of a distinctly tree-like habit; median leaf cells $5^{-7}:$ I.

Americanum

Plants growing in dense tufts so that the tree-like habit is obscured, or prostrate and hypnoid in appearance; median leaf cells $2-3: \mathrm{I}$,

Kindbergii

C. Americanum Brid. Frequent on soil in moist shaded places but fruiting sparingly. Autumn.

C. Kindbergii (R. \& C.) Grout. Common in swamps, often growing in water. Autumn.

C. dendroides (L.) Web. \& Mohr. Yonkers, E. C. Howe, Bx!; “'in swamps about Closter, N. J.," Musc. App. 286.

\section{Subfamily Porotricheae}

Plants dendroid in habit. Leaf cells short and broad. Capsules unsymmetric and inclined, with a perfect hypnaceous peristome. Brotherus in "Die Natürlichen Pflanzenfamilien" puts this subfamily in the Neckeraceae, an arrangement with which I am compelled thoroughly to disagree. All the characters, of our species at least, are hypnaceous except, possibly, the areolation. We have one genus,

\section{POROTRICHUM Brid. (Thamnium B. \& S.)}

P. Alleghaniense (C. M.) Grout. Palisades, N. Y., R. S. W. Bx!; deep shaded crevices in wet rocks, Closter, N. J., Austin, Bx!; "Palisades, not rare," Musc. App. 337.

\section{Subfamily Amblystegieate}

Plants of various habits and habitats. Central strand and costa nearly always present (except Campylium species). Paraphyllia rarely present (except in Cratoneuron). Seta smooth, capsules oblong to subcylindric, cernuous, more or less curved and unsymmetric, usually contracted under the mouth when dry and empty. Leaves acute to slenderly acuminate (except Calliergon). 
KEY

I-Leaves with a distinct border joined with the costa at apex.. Sciaromium

Leaves not bordered.......................... 2

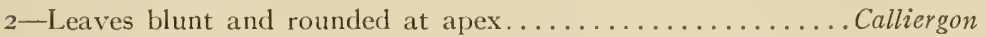

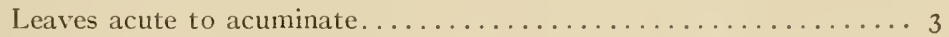

3-Leaf cells very long and narrow (except forms of D. aduncus); leaves mcre or less falcate-secund............... Drepanocladus

Leaf cells much shorter: leaves rarely falcate-secund (except Cratoneuron) . ............................ 4

4-Paraphyllia abundant; plants plainly pinnately branched. Cratoneuron

Paraphyllia very few or lacking ............... 5

5-Leaves widely spreading to squarrose-recurved (except polyganum); leaf cells usually more than six times as long as broad........ Campylium

Leaves not squarrose-recurved; leaf cells usually less than six times

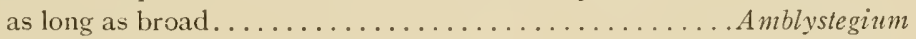

\section{AMBLYSTEGIUM B. \& S.}

Mostly small moisture-loving mosses, growing on various substrata; variously colored, dark green to yellowish, sometimes blackish in the older portions, not glossy. Stems creeping, branching freely and irregularly; central strand present, fewcelled. Leaves spreading to erect when dry, mostly equally spreading, but occasionally somewhat secund, more or less decurrent, lanceolate to ovate, acute to long-acuminate, strongly costate, flat or concave, but not plicate, margins plane. Leaf cells short, often less than 5: I (longer in $A$. vacillans and $A$. riparium); basal cells shorter and broader and parenchymatous; alar often somewhat enlarged, but not abruptly so, not inflated or forming auricles except A. filicinum. Paraphyllia few or more often wanting. Nearly always monoicous. Seta long, smooth; capsules often large in comparison with the gametophyte, inclined to horizontal, elongated and usually strongly curved and constricted under the mouth when dry and empty; operculum conical, not rostrate; annulus usually present; peristome perfect. The genus as here defined does not include the small species having ecostate leaves. They belong in the Hypneae.

The short leaf cells and long capsules, together with the usually small size of the plants, render this genus fairly easy of recognition, but the species, like most aquatic and subaquatic mosses, are exceedingly variable and puzzling. 


\section{KEY}

I-Paraphy!lia abundant, alar cells inflated.............. filicinum

Paraphyllia few or wanting, alar cells not distinctly inflated....... 2

2-Costa percurrent or nearly so, or excurrent................ 3

Costa ending well below the apex, usually not far above the middle. 6

3-Stem leaves entire, cordate-ovate to oblong-lanceolate, apex rather blunt; all forms aquatic......................... 5

Stem leaves narrower in outline, usually acute with a more slender acumen; growing in water or wet places................. 4-Aquatic, submerged except at low water; basal leaf cells usually plainly enlarged; costa very stout .................. irriguum

Growing in wet places but not often submerged; basal cells much less differentiated; costa more slender and apex usually more slenderly.

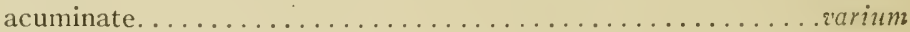

5-Stem leaves oblong-ovate to broadly oblong-lanceolate, $\mathrm{I}-2 \mathrm{~mm}$. in length, gradually and evenly narrowed to a rather blunt apex.

fluitatile

Stem leaves ovate to cordate-ovate, usually less than $1.2 \mathrm{~mm}$. long, more abruptly narrowed to a distinct acumination........ orthocladon 6-Median leaf cells reaching $\mathrm{I} 0: \mathrm{I}$ or longer .............. riparium

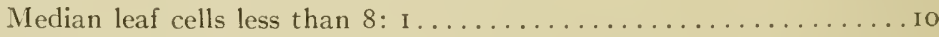
I0-Leaves widely spreading when dry; marginal cells at base of leaf oblong to rectangular........................... I

Leaves not widely spreading; marginal cells at base quadrate or transversely elongated $\ldots \ldots \ldots \ldots \ldots \ldots \ldots \ldots \ldots$ serpens I I-Stem leaves I $\mathrm{mm}$. in length or less, rarely more, ovate-lanceolate.

Juratzkanum

Stem leaves more than I $\mathrm{mm}$. in length; leaves broadly orate-lanceolate to cordate-ovate......................... Kochii

The genus as here constituted divides itself pretty clearly into three subgenera.

Euamblystegium Broth., of which $A$. serpens is the center. Slender plants, not aquatic; leaf cells $2-6$ : $I$, rarely longer; costa slender, reaching to the middle of the leaf or a little farther (to the apex in compactum).

This group includes serpens, Juratzkanum, Kochii and compactum. Kochii is usually put with the next group, but its nearness to Juratzkanum and its wide leaf cells convince me that it belongs here.

Leptodictyum Schimp. contains $A$. riparium and its allied vacillans. The group is characterized by a generally aquatic or subaquatic habitat, long, narrow leaf cells, 8: I, sometimes IO-I5: I, and the costa ending at about the middle of the leaf. 
Hygroamblystegium Loeske, which Brotherus makes a separate genus, contains varium, irrigunm, fluviatile, orthocladon, noterophilum and filicinum, and is characterized by aquatic habitat (excl. varium) and stout, percurrent or excurrent costa; leaf cells 2-4: I, occasionally $6: 1$, thick-walled; paraphyllia present in many species.

A. filicinum (L.) De Not. In wet woods, New Dorp, Court House, and Princes Bay, S. Id., Bx!; "Moist rocks and banks in limestone regions, common," Musc. App. 413; Little Falls and Sussex Co., N. J., Austin, Bx!; Bedford, E. G. B. Spring.

A. fluviatile (Sw.) B.\& S. "On rocks in a rivulet near Closter, N. J.," Musc. App. 386; Willow Brook near Merritt Ave. and spring, Hampton Court!! S. Id.; and West New Brighton, Mosses of S. Id.; Bronx Park, E. G. B. \& R. S. IV., Bx! Summer.

A. irriguum (Wils.) B. \& S. "Common," Musc. App. 376 and 379 , also 360 as $A$. serpens orthocladon. Cool brooks, New Dorp, Princes Bay, Bulls Head, S. Id.; Cold Spring and Oyster Bay, L. Id.!! Summer. Forma Marianopolitana Dupret. Water in swamp, Bulls Head, S. Id.!!

A. Juratzkanum Schimp. On rotten wood, Cold Spring, L. Id.: Richmond, S. Id.!! Early summer. Probably frequent but hard to identify.

A. Kochii B. \& S. Moist shaded soil. Common probably. Yard, 360 Lenox Rd. \& Prospect Park, Brooklyn!!, New Lots, L. Id.; Swamp at New Dorp and at Richmond, S. Id.!!

A. orthocladon (P. B.) Kindb. On stones in brooks. Cold Spring, L. Id. (N. Am. Musci Pl. I89a); Fresh Kills Bridge and Willow Brook, S. Id.!!

A. riparium B. \& S. Frequent in and near water. Spring.

Var. longifolium (Schultz) B. \& S. Orient, L. Id., Latham.

A. serpens (L.) B. \& S. Common on the ground and rotten wood in damp places. Spring. Musc. App. 373-384 are so confused as to be difficult to cite.

A. varium (Hedw.) Lindb. Frequent in moist shaded places. Spring. 


\section{SCIAROMIUM Mitt.}

Distinguished from Hygroamblystegium chiefly by the strongly bordered leaves and entire lack of paraphyllia. In habitat and gross appearance it is the same, also in the cellular structure of the leaves.

S. Lescurii (Sull.) Broth. Stones in brooks, often with Amblystegium orthocladon or A irriguum. Rare. Cold Spring!! I. Id.; "On rocks in mountain rivulets, N. J. \& N. Y.," Musc. App. 37 1. Spring.

\section{CAMPYLIUM (Sull.) Brylın}

Plants growing in moist places, frequently in or near water, usually over earth or stones (except $C$. hispiduhum). The genus is closely allied to Amblystegium, from which it differs in the longer leaf cells and typically squarrose to squarrose-recurved leaves. The leaves are rarely somewhat secund, never falcatesecund or circinate. Branching usually irregular. Central strand of few cells. Leaves broadly lanceolate to ovate-lanceolate, usually long-acuminate and decurrent; alar cells somewhat differentiated, quadrate to hyaline-inflated. Costa usually single, double or lacking in some species, never percurrent or excurrent. Capsules inclined to horizontal, curved and usually contracted under the mouth when dry and empty. Annulus present; peristome perfect.

KEY

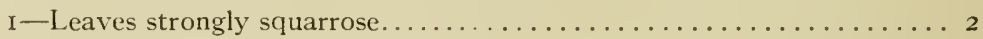

Leaves not noticeably squarrose.................. 4

2-Leaves strongly costate................... chrysophyllum

Leaves without costa or with costa short and double.......... 3

3-Plants very slender; alar cells not conspicuously enlarged or in-

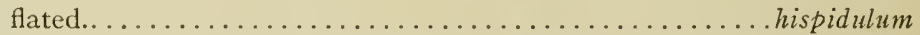

Plants stouter; alar cells conspicuously enlarged and inflated. .stellatum 4-Stem leaves cordate-ovate, abruptly slenderly acuminate; dioicous.

radicale

Stem leaves broadly lanceolate, gradually narrowed to a very long slender acumination; monoicous................ polygamum

Amblystegium Juratzkanum and A. Kochii may be sought in Campylium, but their leaves are spreading from the base and not bent, consequently they will lie Hat on a slide while the 
species of Campylium most likely to be confused with them will not do so.

Plagiothecium striatellum may be sought here, as it has the appearance of a Campylium, but the stem is without central strand, the leaves are serrate and the capsules strongly striate when dry.

C. chrysophyllum (Brid.) Bryhn. "Very common," Musc. App. 394. Most of our material is forma intermedia Grout. Musc. App. 396 (as var. rupestre) is very close to the typical form. Early summer, common on moist shaded soil.

C. hispidulum (Brid.) Mitt. Near or on the ground in moist shaded places. "Common," Musc. App. 392; Garretsons, Princes Bay, Richmond, S. Id., E. G. B.; Yonkers, Howe; Closter, N. J., Austin; Centreport, L. Id., Sanial. Forma compacta Grout, Hempstead, L. Id. (type locality). Summer.

C. polygamum (B. \& S.) Bryhn. "Swamps about Closter, N. J., rare," Musc. App. 40I.

C. radicale (P. B.) Grout. Frequent on soil in swampy woods. "Very common," Musc. App. 39I (as Hypunm bergenense Aust.).

C. stellatum (Schreb.) Bryhn. "WVet meadows near Closter, N. J.," Musc. App. 399. Fredon, N. J. Wiegmann, June.

Var. protensum (Brid.) Roehl. Closter, Austin, Bx!

\section{DREPANOCLADUS C. M. (Plate XI.)}

Of all the mosses this genus is probably the most difficult because of the extreme variability of the plants. Even the recognized authorities in the group identify many specimens by telling what they are nearest rather than by referring them definitely to a described form. Nearly all grow in water or very wet places and the amount of water and other conditions of their immediate environment appear to modify their growth profoundly. Sometimes two well marked varieties.can be found on the same plant. So variable are the leaves that it is absolutely necessary to take fully developed leaves from the older portions of the stem for purposes of study and comparison. In 
removing these, great care must be taken to get all of the leaf as the characteristic swollen alar cells often remain attached to the stems.

Plants slender to very robust, without paraphyllia (there are a few inconspicuous paraphyllia in $D$. uncinatus). Leaves falcate-secund to circinate, often forming conspicuous hooks at the ends of the stem and branches, not papillose, nearly always longly and slenderly acuminate; costa single and well developed, reaching well in to the upper $1 / 3$ of the leaf; leaf cells very long and narrowly linear (shorter in forms of aduncus); alar cells in most species enlarged and inflated, forming more or less conspicuous decurrent auricles; basal cells usually shorter and thicker walled, often porose. Capsules inclined to horizontal, subcylindric and curved, usually somewhat contracted under the mouth when dry, with a perfect hypnaceous peristome.

KEY

i-Leaves entire (excl. forms of revolvens), somewhat narrowed to the nearly straight insertion, with no enlarged or decurrent alar cells but with a row or two of thick-walled broader and shorter cells

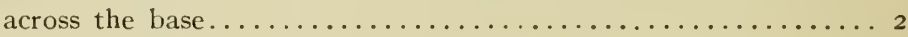

Leaves with alar cells distinctly enlarged and inflated; of ten decurrent or plainly serrate or both........................... 3

2-Plants robust, the older portions usually a deep reddish purple; stems with a central strand; leaves not plicate.......... revolvens

Plants as a rule more slender and less deeply colored; central strand lacking; leaves plicate..................... vernicosus 3-Leaves entire; alar cells usually greatly enlarged and inflated. aduncus

Leaves, some or all plainly dentate................. 4 4 -Leaves strongly plicate even when moist...................

Leaves not plicate; alar cells more or less inflated..........fuitans

D. aduncus (Hedw.) Warnst. Infrequent except in N. J. Austin gives varieties from Little Falls, Musc. App. 405, var. I, which is probably var. gracilescens; No. 407 which is labeled var. gracilescens is not this var. It may be var. aquaticus. Austin calls this form common. Var. gracilescens (Sch.) is reported also from Orient, L. Id., Latham. Summer.

Subspecies Kneifii (B.\& S.) Warnst. "Sunken places about Closter, N. J.," Musc. App. 4 I I ; New Dorp, S. Id., near Moravian Cemetery!! 
Subspecies Sendtneri (Sch.) Warnst. New Haven, Bry. Ct.

Subspecies Wilsoni (Sch.) Roth. Budds Lake, N. J., Austin, and Small, Bx!; Bronx R., Bronx Park, E. G. B., Bx!

D. fluitans (Dill.) Warnst. "Stagnant or sluggish water, common," Musc. App., 4ro, East Marion. L. Id., Latham. Summer.

Var. near var. gracilis (Boulay) Grout covers bottom of small pond near Vanderbilt Mausoleum, New Dorp, S. Id.

Subspecies exannulatus (Guemb.) Warnst. Astoria, L. Id. (H. S.)! labeled Fontinalis.

Var. falcifolius (Ren.) Grout forma viridis (Boulay) Grout pool by road, Cold Spring, L. Id.!!

D. uncinatus (Hedw.) Warnst. Wet shaded places in cool woods. "Near Closter, N. J.", Musc. App., 412; Orange, etc., Bry. Ct. Spring-summer. This is so common elsewhere that it should be found more frequently than is here indicated.

D. vernicosus (Lindb.) Warnst. "In open bogs and marshes about Budds Lake, N. J.," Musc. App. 402.

CALLIERGON (Sull.) Kindb.

Large mosses usually found in swamps and wet places; usually erect when growing in water. Central strand present in the stem. Stem leaves large, not falcate or secund, broadly oblongovate to nearly circular, usually very obtuse and cucullate at apex, very concave, little or not at all plicate, with a single strong costa reaching nearly the entire length of the leaf, or ecostate; leaf cells narrowly linear; capsules unsymmetric, inclined to horizontal, with perfect hypnaceous peristomes.

The old genus Hypnum included nearly the whole family as here treated and it is very difficult to break it up into separate genera satisfactorily. Though usually treated as a subgenus, Calliergon seems to me far better characterized than several other genera of the family that are generally recognized. The first two species placed by Sullivant in Calliergon were Hypuum cuspidatum and $H$. Schreberi which much resemble the other species. here included, but have their leaves ecostate or nearly so. 


\section{KEY}

I-Leaves with a single long strong costa................ 3

Leaves ecostate or with costa short and double............. 2

2-Stems green when fully grown; ends of stems and branches cuspidate with the convolute apical leaves; plants of wet places.......cuspidatum

Stems red; plants of dryer situations. Very common........ Schreberi 3-Branches few; enlarged and decurrent angular cells gradually grading into the others.............................

Pinnately and rather regularly branched; enlarged and swollen cells of auricles abruptly differentiated from the others.......giganteum

C. cordifolium (Hedw.) Kindb. Common in wet swampy places. Spring-summer.

C. cuspidatum (L..) Kindb. "Bogs, common," Musc. App. 444 ; Richmond Hill, L. Id.; Closter and Clifton, N. J.; Yonkers.

C. giganteum (Schimp.) Kindb. Danbury, Ct., Nichols, Bx! Summer.

C. Schreberi (Willd.) Grout. On ground in woods, common, except on L. Id. and S. Id. Reported from Bath and New Lots, L. Id. and Giffords, S. Id. Summer.

\section{SuRFAMILY HyPNEAE}

Central strand lacking or thin and few-celled; leaves of ten strongly falcate-secund, without costa or with costa short and double (except Hygrohypnum sp.); leaf cells linear-flexuose in most species (rhomboidal to linear-rhomboidal in Amblystegiella); capsules oblong to cylindric, typically inclined to horizontal, and unsymmetric to strongly curved, but nearly erect and symmetric in some few species; peristome perfect except in some of the species with erect capsules. This subfamily differs from the last in the slightly developed costa and longer leaf cells. Hygrohypnum is a connecting link.

\section{Key to THE Genera}

I-Branching often regularly pinnate to plumose; leaves strongly falcate-secund; costa short and double or lacking; alar cells usually strongly differentiated............................

Branching irregular; leaves apparently in two rows, complanate, costa as in Hypnum..........Plagiothecium and Hypnum pratense

Leaves neither complanate nor strongly secund, or if strongly secund, with a strongly marked costa $\ldots \ldots \ldots \ldots \ldots \ldots \ldots \ldots \ldots \ldots \ldots \ldots \ldots \ldots \ldots \ldots$ 
2-Leaf cells short, 2-5: I Amblystegiella

Leaf cells usually narrowly linear-flexuose . . . . . . . . . . . 3

3-Costa usually pronounced; aquatic.............. Hygrohypnum

Costa faint or lacking...................... 4

4-Epidermal cells of capsule strongly collenchymatous; operculum

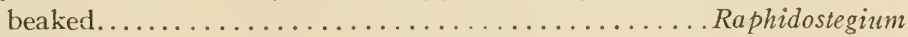

Epidermal cells of capsule not collenchymatous............ 5 5-Alar cells little differentiated.............. Plagiothecium species

Alar cells strongly differentiated, inflated ................ 6

6-Leaves spreading to squarrose as in Campylium; capsules striate.

Plagiothecium striatellum

Leaves imbricated; capsules not striate, long-cylindric.

Hypnum Haldanianum

\section{HYGROHYPNUM Lindb.}

Aquatic or subaquatic mosses growing on stones in and near the beds of brooks, especially in mountainous regions, of ten forming extensive mats, more or less filled in below with sand and gravel. Stems mostly creeping or prostrate, with ascending branches; central strand present, usually few-celled. Leaves in most species usually concave, more or less falcate-secund, comparatively short and broad, soft in texture and often obtuse at apex, rarely acutely acuminate, sometimes apiculate, mostly entire or slightly denticulate at apex; costa double, of varying length, or single and forking, sometimes reaching above the middle; alar cells plainly differentiated, hyaline, colored, or subopaque in the various species, of ten remaining on the stem when leaves are stripped off for examination. Capsules inclined and unsymmetric, rather short and thick; peristome perfect.

Nearest to Drepanocladus, from which it is distinguished by its habitat in running streams and its broader concave more obtuse leaves. Scorpidium is distinguished from this genus by its gigantic size and rugose leaves; Calliergon by its habitat and general appearance. Aquatic Raphidostegia are very close to some species of Hygrohypnum, and Limpricht and Brotherus put Hypnum Novae-Caesareae Austin in this genus, but in general the alar cells of Raphidostegium are more strongly developed, the costa is shorter or wanting, and the operculum rostrate. Certain Brachythecieae, such as B. plumosum or Eurhynchium rusciforme have a similar habitat and appearance, but are easily 
distinguished by the acute leaves, strong single costa and rough seta.

\section{KEY}

I-Alar cells large and conspicuous, clear, hyaline or colored, forming distinct decurrent auricles; outer layer of stem cells much en-

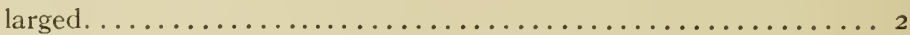

Alar cells thick-walled, less distinctly inflated, granulose to subopaque, often colored; outer layer of stem cells not enlarged..... 3

2-Alar cells hyaline and thin-walled; costa usually reaching the middle of leaf; dioicous............................. ochraceum

Alar cells usually colored and thick-walled, except the outer row or two, which are usually thin-walled and often hyaline; costa double, short and faint; monoicous.................engyrium

3-Costa single, often forking and often reaching above middle....... 4

Costa short and double; leaves denticulate at apex..........dilatatum

4-Plants minute; stem leaves flat, obtuse to suborbicular.......... 5

Plants larger; leaves concave, oval-oblong..............palustre

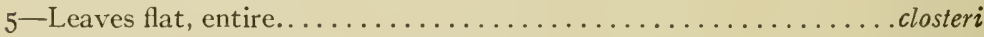

Leaves concave, obsoletely denticulate............... Smithii

H. closteri (Aust.) Grout. "On rocks in streams about Closter, N. J.," Musc. App. 439.

H. dilatatum (Wils.) Loeske. "On rocks along streams, northern N. J., rare," Musc. App. 436 (as Hypnum molle); Darien, Bry. Ct. Summer.

H. eugyrium (B. \& S.) Loeske. Hamden, Beacon Falls, etr., Bry. Ct. Spring.

Var. Mackayi (Sch.) Broth. New Haven, Bry. Ct.

H. ochraceum (Turn.) Loeske. "On rocks along streams, northern N. J.," Musc. App. 437; Yonkers, Howe, Bx! Springsummer.

H. palustre (Huds.) Loeske. "On rocks in mountain rivulets, northern N. J., rare," Musc. App. 435.

H. Smithii (Sw.) Broth. (Hyp. arcticum Sommerf.) "On rocks along rivulets near Closter, N. J.," L. \& J. Manual: 400. This is probably an error in determination. The N. J. plants are probably $H$. closteri. I have not been able to find out conclusively.

Scorpidium scorpioides (L.) Limpr. Margins of pond, Marksboro, N. J. Wiegmann. 


\section{HYPNUM L. (Plate XII.)}

Plants usually more or less regularly pinnately branched, often plumose in appearance. Leaves falcate-secund and in most species apparently arranged in two rows, giving the stems a somewhat flattened appearance on one side (usually the upper) and a bristly appearance on the opposite side. Leaves in most cases long acuminate; costa short and clouble, or lacking entirely; leaf cells linear-flexiıse, 4-20: I', shorter at base; alar cells more or less plainly differentiated, of ten enlarged, hyaline or colored. Paraphyllia present in all our species, few or found only in axils of branches in some cases. Central strand in stem usually present, but few-celled. Capsules subcylindric, more or less curver and cernuous; peristome perfect (excl. H. tenuirostris).

Most of the mosses of this genus have a very similar appearance, due to the leaf arrangement described above and the regularly pinnate and two-ranked branching. Exceptions are IIaldamiamum with its irregular branching; leaves equally spreading, not falcate. $H$. patientiae, $I$. pratense and forms of $H$. cupressiforme are irregularly pinnate. The species grow on all sorts of habitats but many have a marked preference for decaying wood. H. imponens is one of our most common and ty pical species. I ts capsule, however, is more nearly straight and erect than in most species.

\section{KEY}

I-Alar cells inflated, pellucid, hyaline or colored. (Forms of cupressiforme may be sought here) $\ldots \ldots \ldots \ldots \ldots \ldots \ldots \ldots \ldots \ldots \ldots$

Alar cells scarcely inflated, often small and quadrate (fertile and curvifolium may be sought here $\ldots \ldots \ldots \ldots \ldots \ldots \ldots \ldots \ldots$ II

2-Leaves not falcate or secund......................... 3

Leaves secund, usually strongly falcate-secund............. 4

3-Leaves ovate, short-acuminate; inflated alar cells numerous, forming distinct auricles......................... Haldanianum

Leaves ovate-lanceolate, long and slenderly acuminate, not auricled; differentiated alar cells few, not much enlarged........... pratense

4 -Leaves entire or serrulate above only ................. 5

Leaves strongly serrate above; inflated alar cells very conspicuous.... 9

5-Inflated alar cells numerous and conspicuous; capsules plicate when

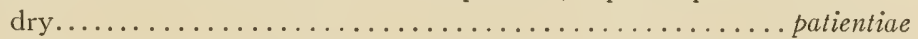

Inflated alar cells rather few........................6 6

6-Not regularly pinnate; habit of Plagiothecium............ pratense

Regularly pinnate............................ 7 
7-Stems reddish; capsules cylindric, little curved and suberect... imponens

Stems not noticeably reddish; capsules curved and inclined.......8 8

8-Plants small, yellowish; capsules not plicate.............fertile

Plants larger, dark green; capsules plicate when dry........curvifolium

9-Leaves in two rows, appearing more or less complanate; capsules curved and inclined; cilia of peristome one or two.......... Io

Leaves not appearing complanate; capsules erect and symmetric or nearly so; cilia none or rudimentary .............tenuirostris

ro-Plants larger, bright glossy yellow-green; urn of capsule twice the length of operculum....................... recurvans

Plants smaller, usually darker green, growing at high altitudes; urn about the length of operculum................ laxepatulum I I-Plants very large and beautifully plumosely branched; leaves plicate.

Crista-castrensis

Plants smaller, less plumose; leaves not plicate............ I2

12-Stems reddish; quadrate alar cells not very numerous....... imponens

Stems not noticeably reddish; quadrate alar cells numerous........ I3

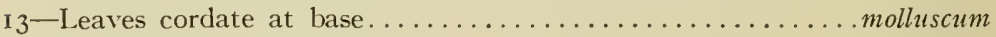

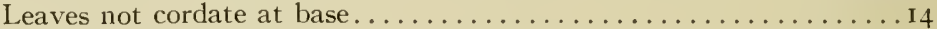

I 4 -Leaves entire or serrulate above.............. cupressiforme

Leaves serrate above, serrulate nearly or quite to base ........ I5

I5-Capsules 2.5-3 mm. long, curved and somewhat contracted below

the mouth when $\operatorname{dry} \ldots \ldots \ldots \ldots \ldots \ldots \ldots \ldots \ldots \ldots \ldots \ldots$ repte

Capsules $\mathrm{I}-\mathrm{I} .5 \mathrm{~mm}$. long, nearly symmetric and not contracted below

the mouth; plants of high altitudes usually .......... pallescens

H. crista-castrensis L. "On the ground and decaying logs in deep damp woods and swamps, Closter, N. J., rare," Musc. App. 434, Cold Spring (27453)!! Summer-autumn.

H. cupressiforme L. "On rocks and roots of trees, N. J.," Musc. App. 422, 423, 42I (Closter); "Not infrequent." Flora L. Id.; Orient, L. Id., Latham; Bard Ave., Silver Lake and New Dorp, S. Id., E. G. B., Bx! (Some of the S. Id. material looks doubtful.)

Var. resupinatum (Wils.) Sch. "On dry rocks, N. J.," Musc. App. 420; Orient, Latham.

H. curvifolium Hedw. Orient, L. Id., Latham; near Huguenot, S. Id., Hollick \& Britton, Bx!; New Haven, etc., Bry. Ct., Musc. App. 424 is $I I$. patientiae, also much of the material in the local collection at the Bronx. Spring.

H. fertile Sendt. Oxford, Bry. Ct. 
H. Haldanianum Grev. Common on decaying wood in damp shaded places. Autumn-winter.

H. imponens Hedw. Conmon on humus and decaying wood in damp shaded places. Autunn-winter.

H. laxepatulum L. \& J. "In cedar swamps, northern N. J. and N. Y.," Musc. App. 34I (as Rhynchostegium recurvans, var.).

H. molluscum Hedw. Common except S. Id., rarely fertile. Summer.

H. pallescens (Hedw.) B. \& S. "On Kalmia latifolia in swamps in the mountains of N. J.," Musc. App. 4I4.

H. patientiae Lindb. Common in damp places, usually on soil. Spring.

$\mathrm{H}$. pratense Koch. On soil in wet places. "Common in N. J.," Musc. App. 425; Jamaica, L. Id. (27509)!!; Palisades, N. J. and New Dorp, S. Id., Bx! Spring.

H. recurvans (Mx.) Schwaegr. Common. Autumn-winter.

Var. resupinatum (Wils.) Sch. Orient, Latham!!

H. reptile $\mathrm{Mx}$. Common, often depauperate and hard to recognize. Bases of trees, stones and decaying wood. Midsummer.

H. tenuirostris (B. \& S.) Broth. "Northern part of the state," Geol. Survey N. J.

\section{RAPHIDOSTEGIUM (B. \& S.) De Not}

Mostly slender mosses with irregular branching; paraphyllia lacking; leaves symmetric and equally spreading or somewhat secund, narrowed to the insertion, not decurrent, concave, not plicate; margins entire or nearly so (except in Norae-Caesareae), strongly reflexed in most cases; costa lacking or short and double; leaf cells linear-flexuose, shorter and broader at base; at basal angles 3-8 large inflated pellucid, hyaline or colored cells, very conspicuous; capsules small, oblong-ovoid, more or less unsymmetric and inclined (excl. R. adnatum); lid beaked, peristome usually perfect. Cell walls of outer layer of capsule strongly 
collenchymatous (i. e., strongly nodulose at points of intersection), in all our species except Novae-Caesareae. This genus differs from Hypnum, subgenus Pseudo-Raphidostegium, in the lack of paraphyllia, less falcate and scarcely secund or serrate leaves, and in the characteristic cell walls of the capsules. All southern, reaching our range as a northern limit. The leaves described in this genus are from the middle of the branches.

I-Plants growing on trees, of Pylaisia habit; capsules erect and symmetric or nearly so.......................... adnahum

Plants growing on rocks and stones, capsules inclined to horizontal....2 2-Leaves suborbicular, serrate.................. Tovae-Caesareae Leares oblong-ovate to oblong-lanceolate; entire or slightly serrulate.

Carolinianum

R. adnatum (Mx.) B. \& S. (Hypnum microcarpum L. \& J. Manual). Bark of living trees. Summer-autumn. Janaica!! \& New Lots, Brainerd (26782)!, L. Id.

R. carolinianum (C. M.) J. \& S. "On damp shaded rock in mountainous regions, Palisades (very rare)," Musc. App. 338 (as Rhynchostegium demissum); "On stones in damp woods about Closter, N. J. Frequent," Musc. App. 339 (as R. microcarpum var. anisocarpon); near Mausoleum pumping Station, S. Id., E. G. B., Bx!; Palisades, N. J. and Bronx Park, Wiegmann.

Var. admixtum (Sulliv.) Grout. Bronx Park, E. G. B.

R. novae-caesareae (Aust.) R. \& C. "On rocks in a small rivulet which crosses the 'State Line' between Shawangunk Mountains near High Point, sterile," Musc. App. 440.

\section{PLAGIOTHECIUM B. \& S.}

Mostly loosely tufted glossy mosses, growing on moist stones and earth, roots of trees and decaying wood; irregularly branching; stems and branches appearing flattened by reason of the complanate leares (except in Roeseanum, pulchellum and striatellum). The twisting to the sides makes some of the leaves unsymmetrical, (except in the species named above) but otherwise they are symmetrical. Stems and branches of ten ending in flagella or stolons; paraphyllia lacking. Stem and branch 
leaves usually much alike, ovate to ovale-lanceolate or oblonglanceolate, little concave, margins usually plane; differentiated alar cells few (except in striatellum and latebricolor); median cells long, linear-flexuose to linear-rhomboidal; costa lacking, or short and double, or forking. Capsules oblong-ovoid to cylindric, usually inclined and more or less unsymmetric (except latebricolor and laetum).

$P$. striatellum, because of squarrose leaves and inflated alar cells, is likely to be sought under Campylium. Hypnum pratense forms are apt to be sought under Plagiothecium because of the complanate leaves. The two subgenera are, by many authors, treated as separate genera, and there are good reasons for so doing, but in a work of this kind conservatism is believed to be most helpful.

\section{KEY}

Mostly very slender plants, light yellowish green to whitish, glossy; leaves little or not at all decurrent; median leaf cells narrowly linear, alar little or not at all differentiated; capsules not plicate (except in turfaceum)....................... Isopterygium

Usually larger, darker green; leaves decurrent; leaf cells wider; alar clearly differentiated; capsules often plicate........ Euplagiothecium

\section{ISOPTERYGIUM Mitt.}

I-Leaves entire, scarcely a trace of serration on any leaf; cortical cells of stem very large; plants of cold ravines, growing mostly in moist crevices of ledges.............................llerianum

Leaves (some or all) more or less serrate................. 2

2 -Leaves strongly serrate in the upper half ................ 3

Leaves serrulate at or near apex only................6 6

3-Plants very slender, usually growing on decayed wood or humus, sometimes on soil............................ 5

Plants largest of the subgenus, resembling Euplagiothecium, growing on earth and stones............................ 4

4-Plants dark green; leaves distant, apex usually bluntish as in Eurhynchium hians......................... geophilum

Plants lighter green, usually yellowish and glossy; leaves closer, not blunt................................. deplanatum

5-Leaves short-acuminate; capsule not striate; operculum rostrate. Groutii

Leaves long and slenderly acuminate; capsules somewhat striate when dry and empty; operculum conic...............turfaceum

6-Plants light yellowish-green; costa very faint or none; growing chiefly in the lowlands from Long Island southwards........micans 
Plants not yellowish, often dark green; costa evident, of ten reaching the middle of the leaf; growing in cool ravines and on mountains.

elegans

\section{Euplagiothecium}

I-Leaves not complanate, squarrose-spreading; capsule strongly

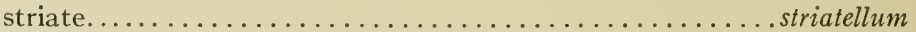

Leaves complanate (excl. Roeseanum)................ 2

2-Plants very slender with habit and appearance of Isopterygium; capsules erect and symmetric; peristomes without cilia... latebricolor

Plants more robust with the habit of $P$. denticulatum......... 3

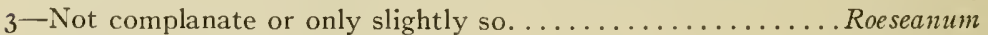

Conspicuously complanate...................... 4

4-Plants dingy or yellowish-green; leaves shrunken when dry; dioicous;

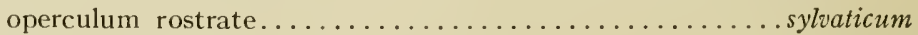

Plants bright green; monoicous; operculum conic ........... 5 5-Edges of leaves strongly incurved and clasping the base of the leaf above, Fissidens-fashion. Plants of swamps...........Ruthei

Leaves not as above or to only a slight degree; plants of varied habitat

denticulatum

P. deplanatum (Sch.) Grout. Closter, N. J., Austin, Bx!; "Palisades, N. J.," Musc. App. 344. [Dr. Best has called this P. silesiacum (Selig.) B. \& S.]. Rarely fertile.

P. denticulatum (L.) B. \& S. Very common on moist soil, stones, etc., in woods. Summer. Forma propagulifera Ruthe, swamp, Valley Stream, L. Id.

P. elegans (Hook.) Sull. "Crevices of shaded rocks, northern N. J.," Musc. App. 348, also 350 from Suffern, N. Y., as var. gracilens.

P. geophilum (Aust.) Grout. "On clayey shaded ground, N. J.," Musc. App. 345; Richmond, S. Id.!! Spring.

P. Groutii Card. \& Ther. Type from hollow in base of chestnut tree, Hempstead, L. Id. A subspecies of $P$. micans.

P. latebricolor (Wils.) B. \& S. "About the roots of old stumps, etc., in swamps near Closter, N. J.," Musc. App. 353. Flushing, L. Id.!! Rare; autumn.

P. micans (Sw.) Paris. Frequent on rotten wood and soil at base of trees. Lawrence, L. Id.!!; Ocean Terrace, S. Id.; Closter, N. J.; Pelham Parkway, the Bronx. January. 
P. Muellerianum Sch. "Rocky ravines, N. Y. \& N. J.," Musc. App. 35I ; Pascack and Closter, N. J., Austin, Bx!; Hamden, Bry. Ct. This rare species usually grows in damp crevices of shaded ledges.

P. Roeseanum (Hampe) B. \& S. A subspecies of P. denticulatum, frequent on damp peaty soil and shaded rocks and banks, Closter, N. J.; Gowanus and Glen Cove, L. Id.; Bulls Head and Tottenville, S. Id.!!

P. Ruthei Limpr. Common on peaty soil along the south shore of L. Id. (N. Am. Musci Pl. 55); Bulls Head, S. Id., and probably frequent along the coast. A subspecies of $P$. denticulatum.

P. striatellum (Brid.) Lindb. Very common on hummocks in swamps. Summer.

P. sylvaticum (Huds.) B. \& S. Frequent in damp woods. There are innumerable intergradations between this and $P$. denticulatum.

P. turfaceum Lindb. "On the ground in woods and on decayed wood in cedar swamps, Palisades, N. J.," Musc. App. 356; decayed trunk of pollarded willow, Richmond, S. Id.!!, and also stumps at New Dorp, E. G. B., Bx!

(P. passaicense Aust., Musc. App. 353, from Bergen Co., N. $\mathrm{J}$., is probably a form of $P$. latebricolor. P. subfalcatum, Musc. App. 366 is regarded by Kindberg as a form of $P$. denticulatum.)

\section{AMBLYSTEGIELLA Loeske}

Usually treated as a section of Amblystegium, but differing from the true Amblystegia in the smaller size, lack of central strand and in the slightly developed costa, which is either wanting or very faint. Nearly all our species, except adnata, have a tendency to become stoloniferous and the leaves on the stolons are much smaller than the normal leaves. Therefore, welldeveloped leaves should be sought for study.

I-Plants of the size and habit of Hypnum reptile; leaves reaching more

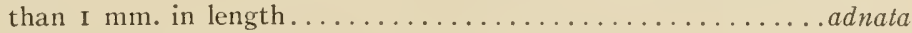
Plants minute; leaves not over $0.6 \mathrm{~mm}$. in length........... 2 
2-Leaves narrowly triangular-lanceolate, not narrowed to insertion; alar cells at margin all longer than broad; median 5-10: I.

minutissima

Leaves narrowed to insertion; median cells shorter, alar quadrate. confervoides

A. adnata (Hedw.) Nichols. On stones and base of tree in sliaded places, frequent. Summer.

A. confervoides (Brid.) Loeske. "On limestone rocks, N. J.," Musc. App. 368, Sussex Co. and Hohokus, N. J., Aust., au thenticated by L. S. Cheney, Bx!

A. minutissima (Sull. \& Lesq.) Nichols. "In old wells, northern part of the state," Geol. Survey N. J.

\section{Subfamily Entodonteae}

Plants of large or medium size, none minute, typically hypnaceous; leaves not papillose, of ten concave or plicate or both; costa lacking or short and double; median leaf cells linear; alar quadrate (in our forms): seta smooth; capsule erect, straight, not conspicuously contracted under the mouth when dry; peristome with cilia rudimentary or wanting, segments of ten narrow and basal membrane sometimes nearly lacking.

This group has contained a heterogeneous collection of mosses of various relationships, their association being based upon the erect capsule and incomplete peristome. I have shown elsewhere that a degeneration of the inner peristome is associated with erect capsules even though it may not (as I think it is) be a result as well. There is no more reason why Homalothecium or Climacium should be placed in this subfamily than there is for doing the sane with Brachythecium acuminatum or even Plagiothecium latebricolor.

\section{Key to Genera}

I-Plants robust, glossy yellow-green; leaves symmetric but very con-

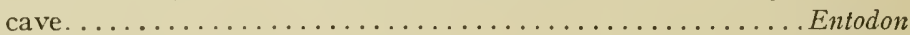

Plants slender, dark green, rarely glossy................

2-Leaves somewhat falcate, ends of branches curved when dry...Pylaisia

Leaves not falcate, branches not curved............ Platygyrium

ENTODON C. M. (Cylindrothecium B. \& S.)

Growing in wide intricate glossy yellow-green mats; stems densely leafy, turgid with the very concave leaves or in most species 
somewhat flattened. Leaves nearly entire or very slightly serrate at apex, very concave, not striate or plicate when $d r y$, ecostate or with costa very short and double; leaf cells linear, enlarged and quadrate at the basal angles: capsules cylindric, erect and symmetric; operculum conic to conic-rostrate, annulus usually large and conspicuous, remaining attached longer than is usually the case; peristome with cilia rudimentary or wanting and segments narrow, basal membrane usually very narrow.

Their brilliant color and flattened habit (julaceous in $E$. seductrix) render this genus easy of recognition. The leaves are so much nearer together than in most other flattened forms that one is not likely to put them with forms like Plagiothecium. In fruit Brachythecium acuminatum is our only moss likely to be misplaced in this genus.

\section{KEY}

I-Leaves gradually narrowly acuminate; segments of endostome ad-

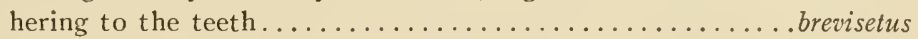

Leaves merely acute or apiculate, segments free............ 2

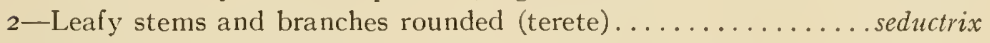

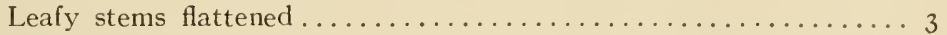

Plants robust; capsules $3-5 \mathrm{~mm}$ long, 5-6:1, peristome teeth not

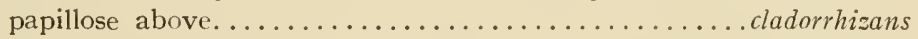

Plants more slender; capsules $2.5 \mathrm{~mm}$ long, $4: \mathrm{I}$, teeth papil-

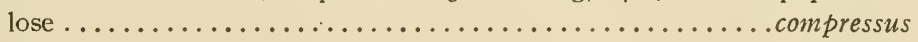

E. brevisetus (Hook \& Wils.) J. \& S. "On leaning trunks of trees, old logs and stone fences; also on rocks associated with Dicranum scoparium var. rupestre, Palisades and northern N. J.," Musc. App. 285.

E. cladorrhizans (Hedw.) C. M. Cold Spring (25906)!! and Northport, Sanial on L. Id.; "Palisades and northern N. J.," Musc. App. 284. Autumn. Much of the local material at the Bronx is E. seductrix.

E. compressus (Hedw.) C. M. "On decayed stumps of trees, Weehawk, N. J.," labeled in Torrey's handwriting in the Torrey Herbarium at the Bronx.

E. seductrix (Hedw.) C. M. Common. A specimen from Barnes' Woods, S. Id., E. G. B., Bx! resembles E. compressus in appearance and should probably be referred to var. Demetrii 
(R. \& C.) Grout, although some of the branch leaves are serrulate. Autumn--winter.

\section{PLATYGYRIUM B. \& S.}

The nicroscopic structure of this genus is so like that of Entodon that I placed it in that genus in my monograph (Bull. Torr. Bot. Club 23: 227), but the dark-green scarcely glossy appearance and the small terete branches much more closely resemble Pylaisia than Entodon.

From Pylaisia this species is distinguishable by the fact that the leaves are not at all falcate-secund and the branches are little if any curved at the ends. The ends of the branches often bear gemmae in the axils of the leaves.

P. repens (Brid.) B. \& S. On bark of trees, on logs and stumps. Frequent. Smithtown and Jamaica, L. Id.; IVillow Brook!! and Todt Hill, S. Id.; Bronx Park, Pelham Parkway, Yonkers; Closter. Autumn.

\section{PYLAISIA B. \& S. (Not Desr.)}

A genus of tree-growing mosses sometimes found on fallen trunks, usually easy of recognition by reason of their slender branches, curved when dry and almost hooked at the ends by reason of the falcate-secund leares and also by their small erect and cylindric capsules, having very degenerate inner peristomes; cilia lacking (or very rudimentary in polyantha) and of ten having the segments adherent to the teeth. The leaves are ecostate or with costa short and double, concave, entire or slightly serrulate above. The annulus is much narrower than in Platygyrium or Entodon (except E. seductrix).

\section{KEY}

I-Segments of endostome free from the teeth...........subdenticulata

Segments of endostome wholly or partially adherent to the teeth....2 2-Segments partially adherent; spores $18-24 \mu \ldots \ldots \ldots \ldots$. Schimperi

Sigments wholly adherent, $25-70 \mu \ldots \ldots \ldots \ldots \ldots \ldots \ldots \ldots$ intricata

P. intricata (Hedw.) R. \& C. ( $P$. velutina Schimp.) Van Cortland Park, E. G. B., Bx!; "On trees in swamps and in mountainous regions, N. J.," Musc. App. 293; Yonkers, E. C. Howe. 
P. Schimperi R. \& C. (P. intricata B. \& S.). Frequent on apple and shade trees beyond city conditions. Autumn.

P. subdenticulata Schimp. "On bases of white oaks about Closter, N. J.," Musc. App. 290. " Richmond Hill," Flora L. Id.

\section{FAMIIY 23. FABRONIACEAE}

Smallest and most delicate of the Pleurocarpi except $\mathrm{Am}$ blystegiella. Mostly plants of warmer regions, growing in rather thin tufts, often glossy. Stems without central strand, creeping, producing many erect and simple or somewhat divided branches; paraphyllia lacking; branches densely leafy; leaves soft, rarely or not at all complanate or secund, closely imbricate when dry, not decurrent or plicate, ovate to ovate-lanceolate, acuminate, entire in some species, ciliate-dentate in others; costa lacking or single and extending $\mathrm{I} / 2$ length of leaf; leaf cells thin-walled (except Habrodon), median linear-rhombic to hexagonal; basal and alar often quadrate to short rectangular; none papillose; capsule erect and symmetric, cylindric to ovoid, often strongly contracted under the mouth when dry and empty; peristome single or double, the outer 16 teeth of ten united in pairs and reflexed as in Orthotrichum; segments of inner peristome, when present, narrowly linear. Rare in our range, usually on trecs.

KEY TO THE GeNerA

I-Leaves ciliate-dentate

Fabronia

Leaves entire

$2-3$ or 4 rows of quadrate to rectangular basal cells; peristome

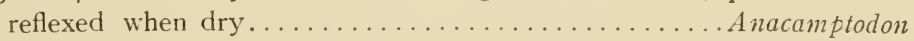
Roundish-quadrate cells extending well up leafmargins .... Clasmatodon

\section{ANACAMPTODON Brid.}

A. splachnoides (Froelich) Brid. Our only species, dark green; leaves ovate-lanceolate, acuminate, entire; leaf cells rhombic-hexagonal, quadrate to rectangular at base: seta 5-8 mm. long, annulus lacking; peristome double; teeth approaching each other in pairs and reflexed when dry; segments filiform with no basal membrane; spores papillose, maturing in June. Moist 
cavities in decaying wood especially knotholes in living trees. Cheshire, Hamden, and New Haven, Bry. Ct. Should be found nearer.

Clasmatodon parvulus (Hampe) Sull. and Fabronia octoblepharis (Schleich.) Schwaegr. are found at the Delaware Water Gap.

\section{FAMily 24. LEUCODONTACEAE}

Tree-growing mosses, rarely found on rocks, often julaceous and glossy; main stems slender, creeping, irregularly branching; secondary stems numerous, horizontal to drooping and outwardly curved, paraphyllia lacking in most species; leares of secondary stems ovate to ovate-lanceolate, concave, costate or ecostate, entire or nearly so, closely imbricate when dry, spreading when moist, not papillose; leaf cells short, roundish-oval to fusiform in the middle portion of the leaf; perichaetial leaves long-sheathing, seldom much shorter than the seta and of ten extending beyond the capsule; capsules erect and symmetric, mostly ovoid; peristome simple.

\section{Key to Genera}

I-Secondary stems little branched; calyptra not hairy ............

Secondary stems freely branching, often subpinnate; calyptra

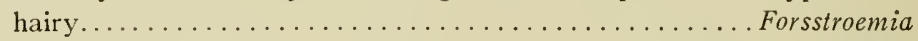
2-Plants very slender; capsule immersed; seta almost lacking. . . . Cryphea

Plants stouter; seta much longer than capsule........... Leucodon

\section{LEUCODON Schwaegr.}

The various species of Leucodon grow almost exclusivèly on the bark of deciduous trees, very rarely are any found on dry rocks. The Leucodons are seemingly able to do without moisture for considerable periods, as they rarely or never grow at the base of trees, but at a height of five or six feet and above. The main stems are long, slender, branching, almost filiform, with minute leaves and abundant rhizoids. The secondary stems are numerous, suberect, horizontal, or hanging downward and curved outward, usually julaceous and nearly simple; paraphyllia lacking. Leaves many ranked, concave, with margins recurved below, ecostate, entire or slightly serrulate at apex, 
closely appressed when dry, spreading when moist; leaf cells thick-walled; several rows of marginal cells roundish-quadrate; the lower median linear-fusiform, gradually changing to oval at the apex; basal cells often brownish or reddish yellow. Dioicous. Calyptra cucullate, smooth, often attached below the capsule by the connate base. Capsules exserted or emergent, erect and symmetrical; peristome apparently simple, teeth 16 , articulate and papillose, bifid or occasionally trifid; inner peristome reduced to a narrow inconspicuous membrane.

L. brachypus Brid. Orient, Latham; Guilford and New Haven, Bry. Ct.

L. julaceus (Hedw.) Sull. Moriches (H. S.!), Bath, Brainerd and Cold Spring!!, L. Id. “On trees common” Musc. App. $25^{8}$.

\section{FORSSTROEMIA Lindb.}

\section{(Leplodon of L. \& J. Manual)}

Much like Leucodon, but distinguished in all our species by the abundant branching of the secondary stems and by the hairy calyptra. Many species have strongly costate leaves and most are less glossy than Leucodon.

F. trichomitria (Hedw.) Lindb. Common on trees and rocks, Musc. App. 254; Closter, Austin, Bx!

CRYPHEA Mohr.

Cryphea glomerata B. \& S. "Red Cedars, Palisades, N. J., rare," Musc. App. 253.

\section{FAMILY 25. NECKERACEAE}

Mostly growing on rocks and trees. Primary stems creeping and defoliate; secondary stems erect, horizontal, or pendent, irregularly to pinnately branching; leaves large, ovate-lanceolate to lingulate or cultriform, acute, obtuse or apiculate, ecostate or with a slender costa; leaf cells not papillose, short, rhombic to linear, quadrate to roundish on the margins. Calyptra smooth or hairy; capsule erect and symmetric, immersed or emergent, rarely with seta longer than perichaetium; peristome single or double. 


\section{Kex to Genera}

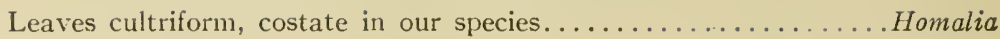

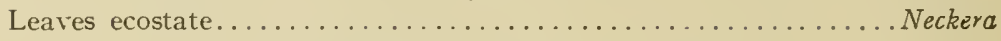

\section{HOMALIA (Brid.) B. \& S.}

Leaves costate and capsule long-exserted.

H. Jamesii Schimp. Hamden, Bry. Ct.

NECKERA Hedw.

Plants usually large (excl. gracilis), growing on trunks of trees or rocks; primary stems creeping, of ten stoloniferous; secondary stems erect to pendent, of ten pinnately branched, usually complanate-foliate; stems and branches sometimes flagelliform; leaves often transversely undulate, ovate-lanceolate to oblong or lingulate, frequently unsymmetric, ecostate or nearly so; leaf cells broadly rhomboidal at apex and upper margins, changing to linear-oblong to linear-flexuose at base; capsules immersed or exserted; peristome double, the inner a short membrane with short segments or with segments longer and narrowly linear, cilia wanting; annulus lacking.

\section{KEY}

I-Leaves ovate-lanceolate, undulate, acute. pennata

Leaves oblong, not undulate, rounded at apex, often apiculate; plants filiform.............................

N. pennata (L.) Hedw. Closter, N. J., Austin, Bx!; “On trees and rocks, common," Musc. App. 255.

N. gracilis (James) Kindb. (Homalia gracilis James). "Under overhanging rocks, Palisades, N. J.," Musc. App. 257.

\section{FAMILY 26. FONTINALACEAE. WATER MOSSES}

Aquatic, floating, usually slender, attached at base of stems only, of ten very long, dark to blackish green, especially below. Central strand lacking in the stems. Leaves ecostate in Fontinalis, costate in Dichelyma, mostly decurrent, entire or slightly denticulate at apex; leaf cells rhomboid-hexagonal to linear-flexuose, broader and shorter at base of leaf and often at apex also. 
Seta short; capsule immersed in the perichaetial leaves or shortly exserted, without neck or stomata; annulus lacking; peristome double, the outer composed of 16 teeth, the inner of 16 linear divisions more or less completely united by cross strands at regular intervals, forming a regular net or trellis through the meshes of which the spores gradually escape.

Although mosses belonging to several other families are aquatic, the mosses of this family are most emphatically entitled to the name of Water Mosses, as the members of the family are either submerged all the time or attached to objects that are submerged at high water.

\section{KEy to the GeNera}

Costa lacking, leaves mostly symmetric.................. Fontinalis Costa present, leaves mostly falcate-secund. Dichelyma

\section{DICHELYMA Myr.}

Plants growing near the edge or surface of the water, generaliy submerged at high water, shorter than Fontinalis with the appearance of Drepanocladus; leaves three-ranked, costate, narrowly lanceolate, secund to falcate-secund; leaf cells narrow, linear; basal shorter, brownish, not forming auricles. Dioicous; perichaetium very long, cylindric, the leaves convolute, very long, spirally twisted, ecostate; seta of moderate length enclosed by the perichaetial leaves, sometimes longer and sometimes shorter than the perichaetium; peristome much as in Fontinalis, but the teeth shorter than the inner peristome.

D. capillaceum B. \& S. Frequent on sticks and stones in water. Ridgewood (25473) and Gowanus (25474), Northport, Orient, Forest Park (25475)!!, L. Id.; Red Lane and Court House, S. Id.; "Common," Musc. App. 252.

\section{FONTINALIS Dill.}

Stems usually denuded of leaves below, long slender and floating, freely branched, usually blackish green, except the latest growth; leaves ecostate, sometimes nearly flat, but usually strongly concave to nearly tubular. (The young undeveloped leaves at the ends of the shoots are always convolute.) Median leaf cells 
linear, of ten long and narrow; alar cells subrectangular to subhexagonal, forming more or less distinct auricles. Dioicous; capsules sessile, little exceeding the perichaetial leaves; outer peristome teeth long, sometimes united at apex.

All our species are submerged, some grow attached to stones and sticks in swift brooks, others in ponds and sluggish streams. Rarely, if ever, are they found in stagnant water. By reason of the peculiarities named the genus is easy to recognize, but the species are of ten difficult or impossible to distinguish without authentic specimens for comparison, as there is relatively very little difference in the areolation of the leaves.

I have used to a very great extent the monograph of the family by M. Jules Cardot and hereby acknowledge my indebtedness to him, although I must confess that his eyesight for specific distinctions seems to be considerably more acute than mine. The difficulty of identifying sterile and poorly developed forms is emphasized by the fact that all the older American exsiccati are badly mixed.

\section{KEY}

I-Plants very large, leafy stems triangular, $5^{-7} \mathrm{~mm}$. in diameter; leaves

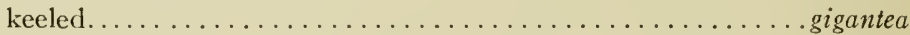

Plants much smaller, not evidently three-cornered; leaves concave but not keeled. . . . . . . . . . . . . . . . . . . . . . 2

2-Plants very slender and rather rigid; leaves oblong-lanceolate to narrowly lanceolate. . . . . . . . . . . . . . . . . 3

Plants much stouter; leaves broader, oblong-lanceolate to ovate..... 4 3-Stem and branch leaves markedly different; stem leaves 4-6 mm. long, very longly and slenderly acuminate.......... Sullivantii

Stem and branch leaves little different, 2-3 mm. long, much less slen-

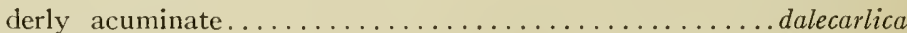

4-Ieaves distant, loosely erect-spreading, usually plane or slightly concave above, rather slenderly acuminate, acute or somewhat obtuse, soft.....................................

Leaves less spreading, closer, concave and of ten cucullate above, less slenderly acuminate, more broadly obtuse, more rigid...novae-angliae

F. dalecarlica B. \& S. "Rocky rivulets, common," Musc. App. 25I, Closter, Austin, Bx!; Fairy Dell, Quogue, Mrs. J. K. Creevy (25425).

F. gigantea Sull. Frequent in brooks. Not reported from S. Id. Summer. 
F. Lescurii Sull. Bulls Head, Pleasant Plains (N. Am. Musci Pl. 428, det. Cardot) and Court House, S. Id.; Yonkers, Howe; 246, 247, 248 Musc. App. labelled this species are $F$. novae angliae according to Cardot. Most of the S. Id. material at the N. Y. Bot. Gardens labeled F. biformis is this species or F. Sullivantii.

F. novae-angliae Sull. New Dorp!! and Egbertville and Tottenville, S. Id.; Common in N. J. according to Austin (See the preceding); Flushing, L. Id., Hulst, Bx!

F. Sullivantii Lindb. "Stagnant pools in woods about Closter, N. J.," Musc. App. 249, also Suppl. 524, according to Cardot; Toms R., N. J., E. G. and N. L. Britton, Bx!; Greenport, Latham; Court House, S. Id. E. G. B.!; Bronx Park, E. G. B., Bx!

F. involuta R. \& C. According to Cardot part of Musc. App. 248 from Ponds of $\mathrm{N}$. J. is this species. Gilman has a specimen from "Near State Line, N. Y. \& N. J.," at Bx!; Manchester, N. J., fide Cardot.

Distinguished from $F$. novae-angliae by the narrower leaves, strongly involute on the borders, canaliculate and cucullate at the apex; generally appearing distichous. Fide Cardot.

F. microdonta Ren. "New Jersey," Cardot, Monographie des Fontinalacées: 121. Distinguished from $F$. Sullivantii by its less rigid appearance, softer leaves, and rudimentary inner peristome. Fide Cardot.

\section{ADDENDA (Reported by Wiegmann)}

Dicranum Muhlenbeckii B. \& S. On bare limestone with Carex eburnea, Swartswood N. (49 miles from City Hall.)

Dicranum spurium Herw. Bare trap rock. Plainfield, $N$. J. Fissidens incurvus Schwaegr. Wiegmann reports spores mature in August in brooks at Alpine, N. J.

F. Julianus (Sari.) Sch. Bronx R. below falls in Bronx Park. Encalypta streptocarpa Hedw. Crevices in dolomite ledges, 23 Ist St. and Broadway, N. Y. City.

Bryum Duvallii Voit. Swartswood, N. J. Doubtful. 



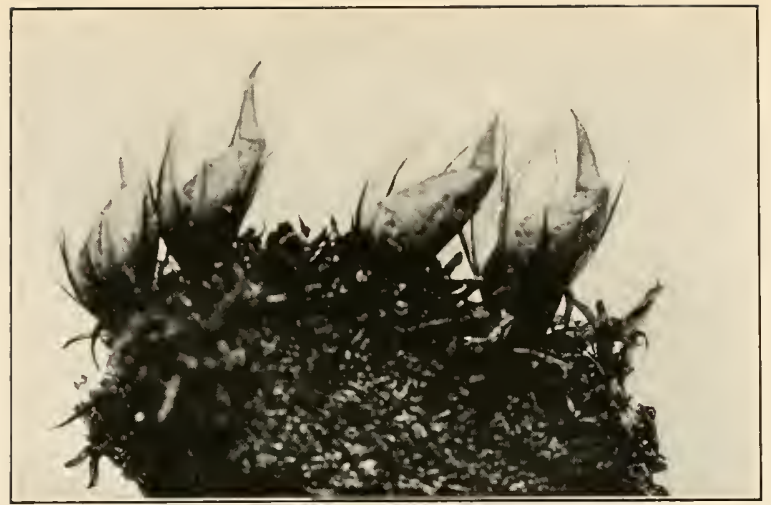

FIG. I-Webera sessilis $\times 5$

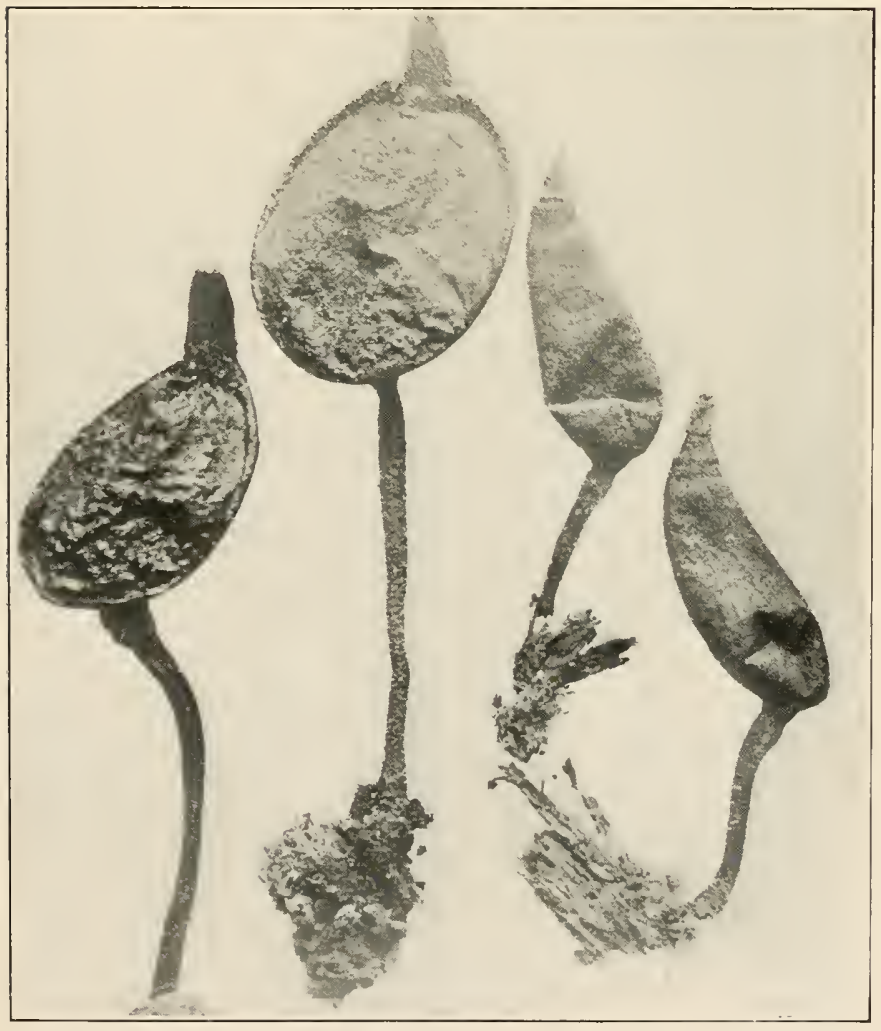

Fig. 2.-Buxbaumia $\times$ 9. B. aphylla (left) and B. indusiata right). From herbarium specimens 

Plate II

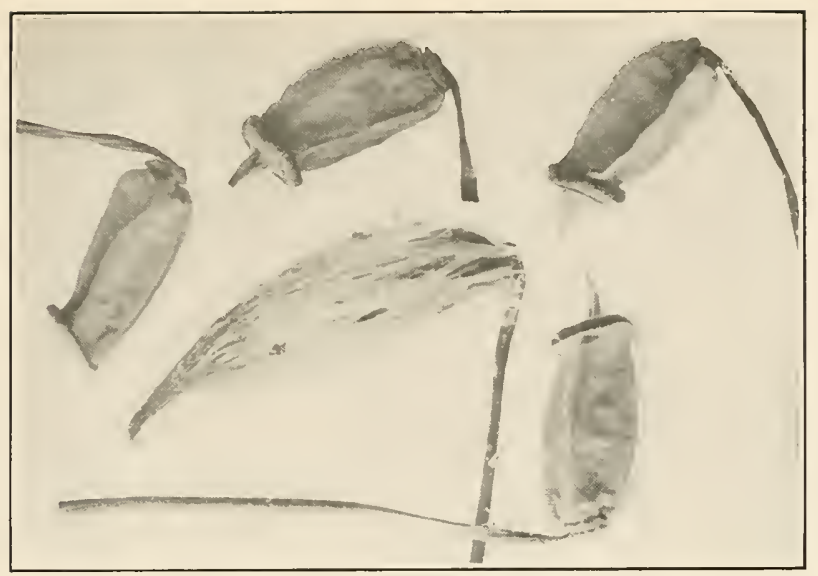

FIG. I.-Capsules of Polytrichum juniperinum $\times 5$.

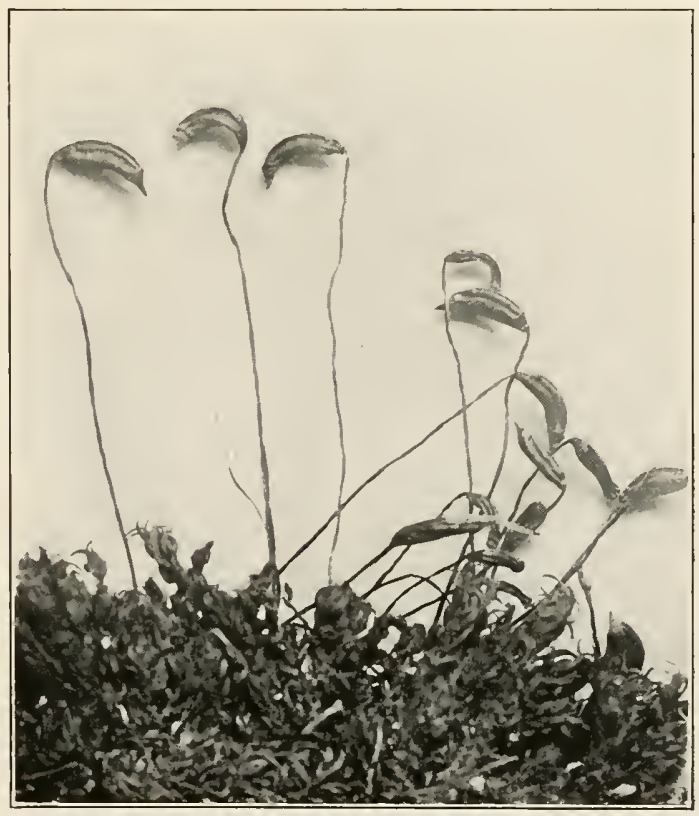

FIG. 2.-Ceratodon purpureus, dry. $\times 5$. 



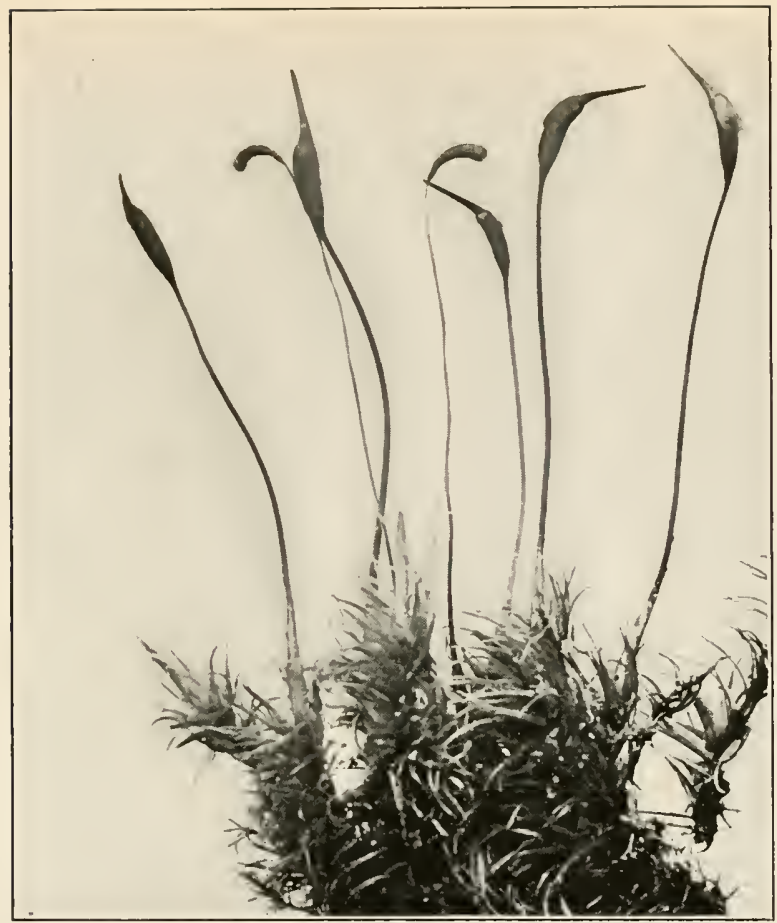

FIG. I.-Dicranum scoparium, nearly $\times 2$, showing the sporophytes for 3 successive years

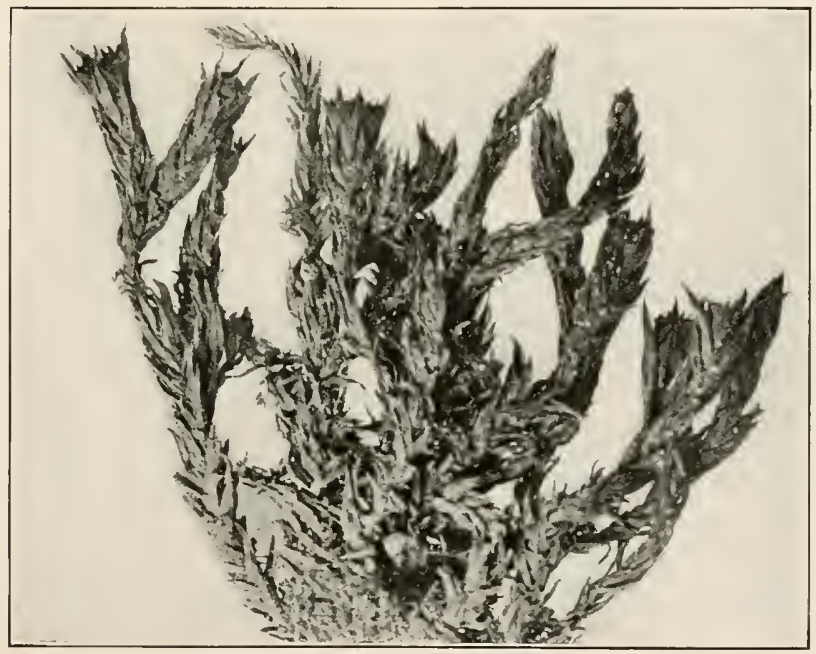

FIG. 2.-Grimmia apocarpa $\times \mathbf{5}$ 

Plate IV.

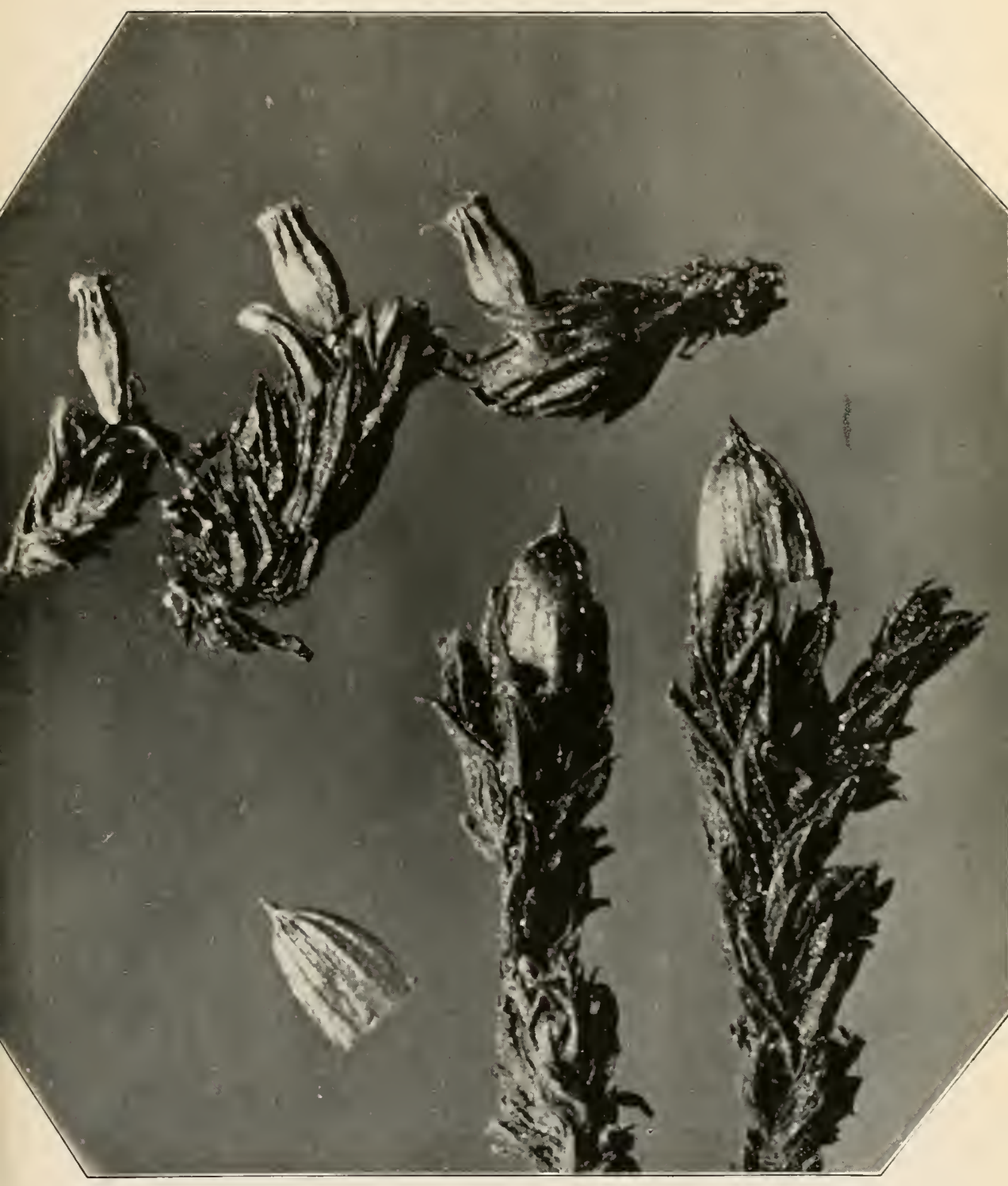

Orthotrichum strangulatum $\times$ I5 

Plate V.

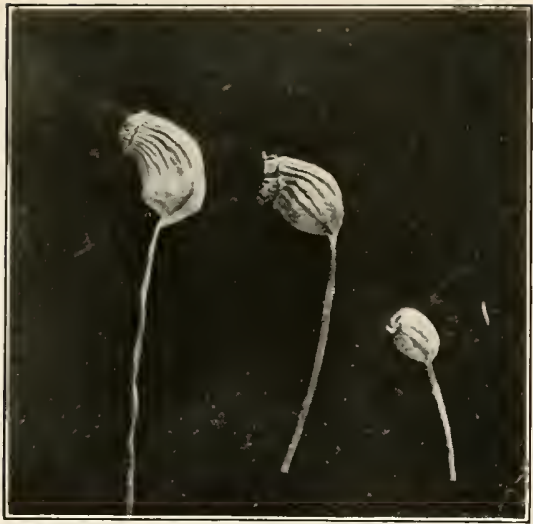

FIG. I.-Capsules of Philonotis fontana, Bartramia pomiformis and B. Oederi $\times 4$

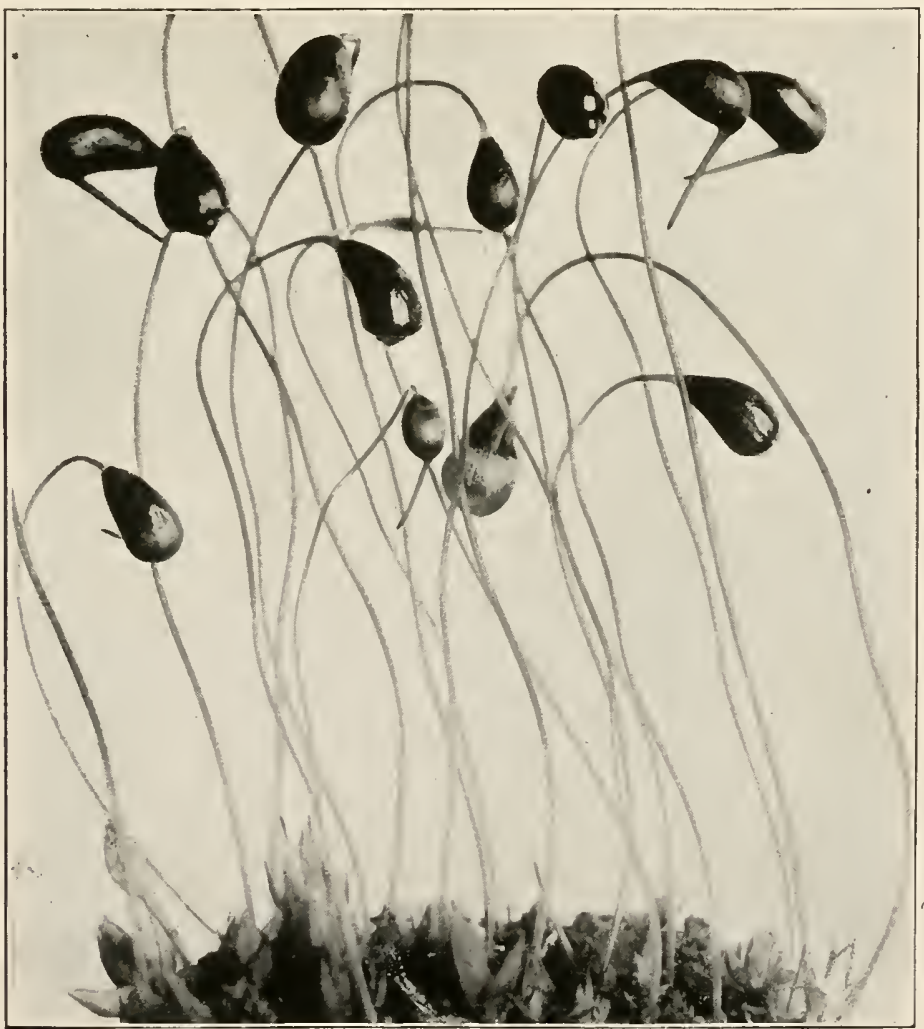

FIG. 2.-Funaria hygrometrica $\times 4$ 

Plate I'I.

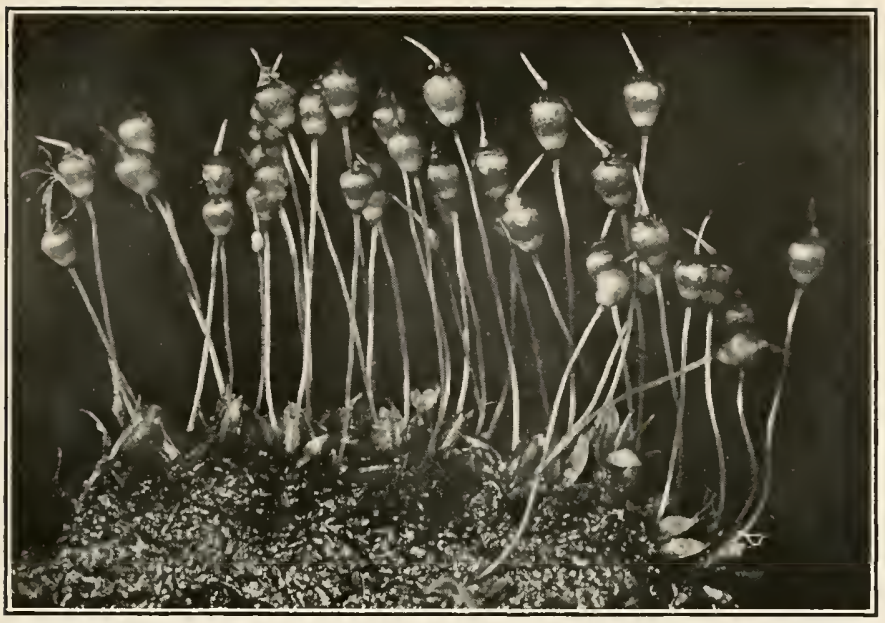

FIG. I.-Physcomitrium turbinatum $\times 4$

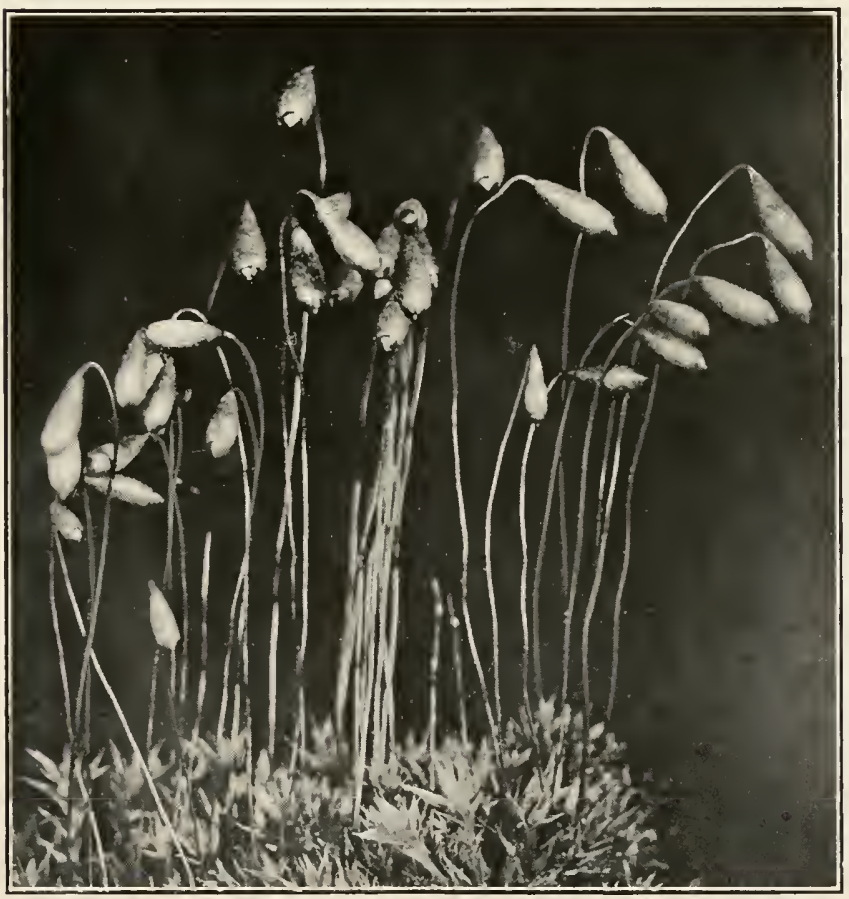

FIG. 2.-Bryum caespiticium $\times 2$ 

Plate ViI.

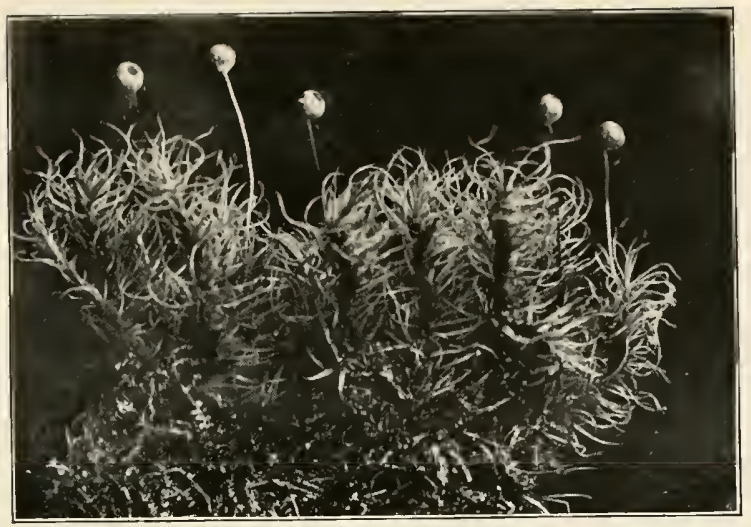

FIG. I.-Bartramia pomiformis $\times 2$

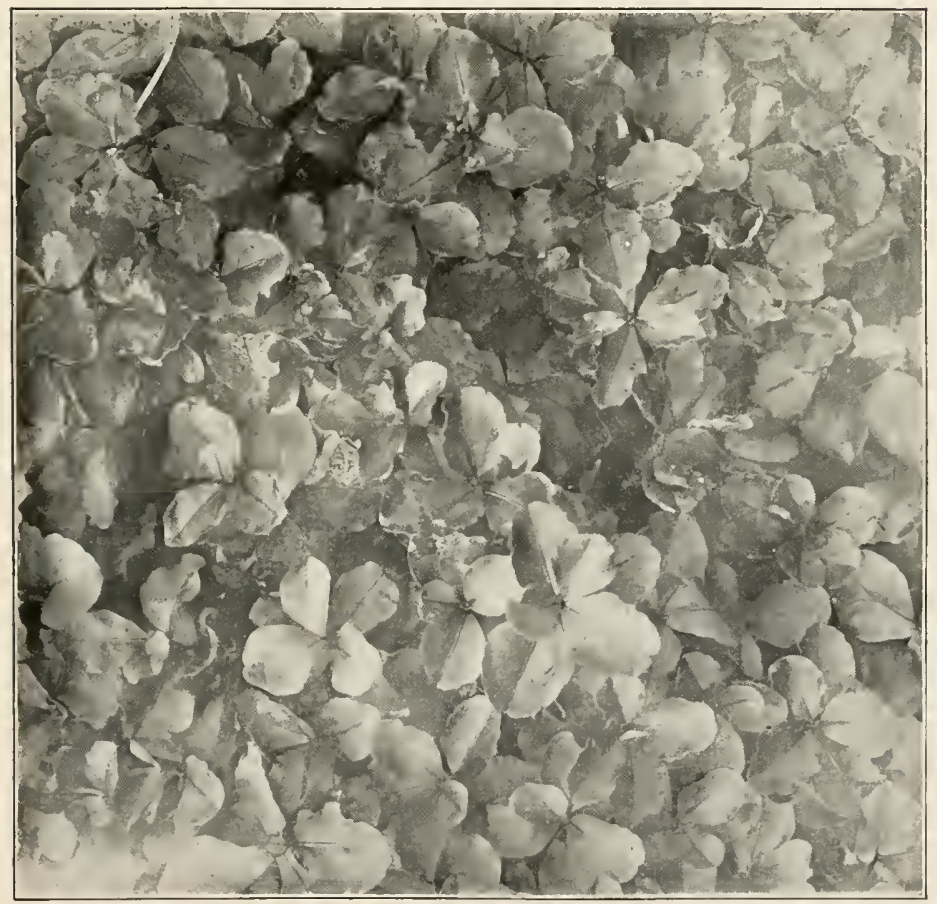

FIG, 2.-Mnium punctatum elatum, slightly enlarged 

Plate Vili.

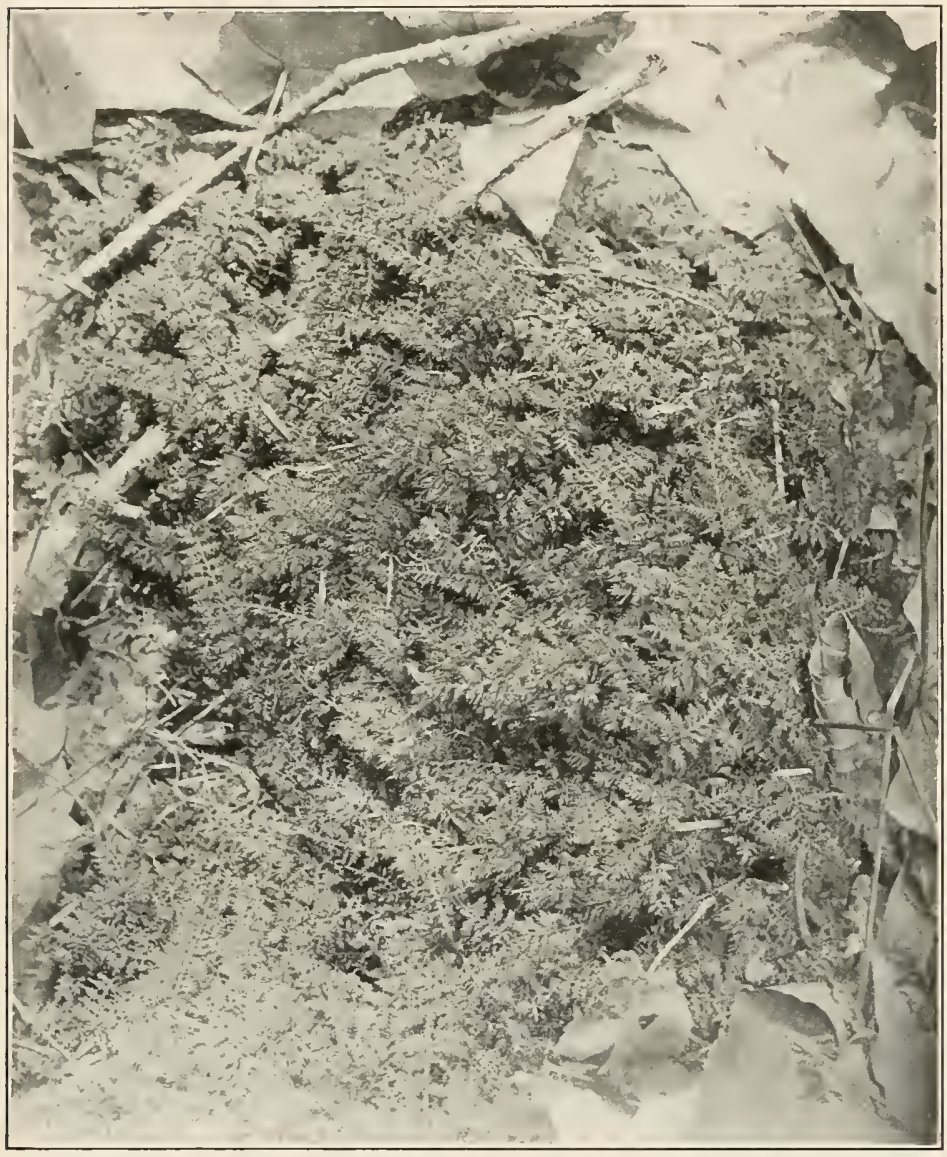

Thuidium delicatulum in situ, slightly reduced 

Plate IX.

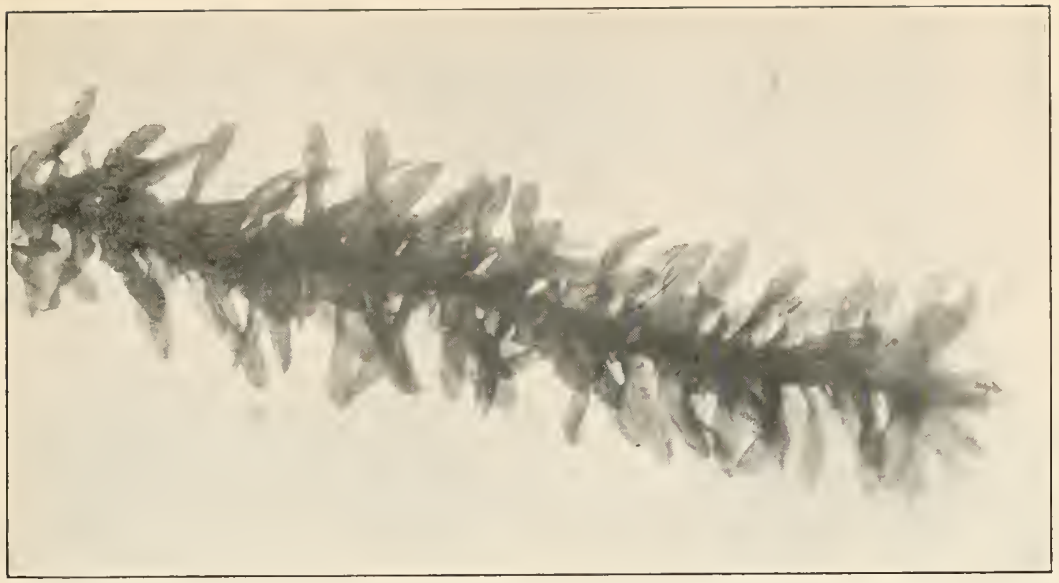

FIG. I. - A nomodon minor $\times 8$

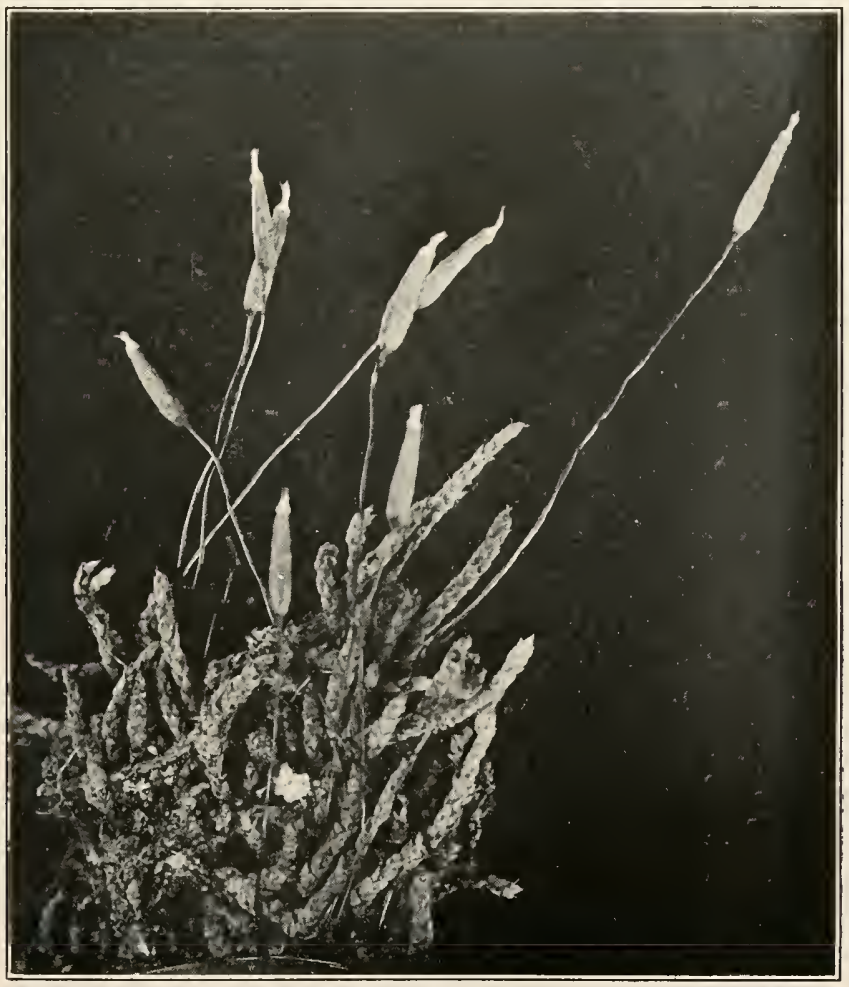

FIG. 2. - Theliu hirtella $\times 5$ 



\section{Plate X.}

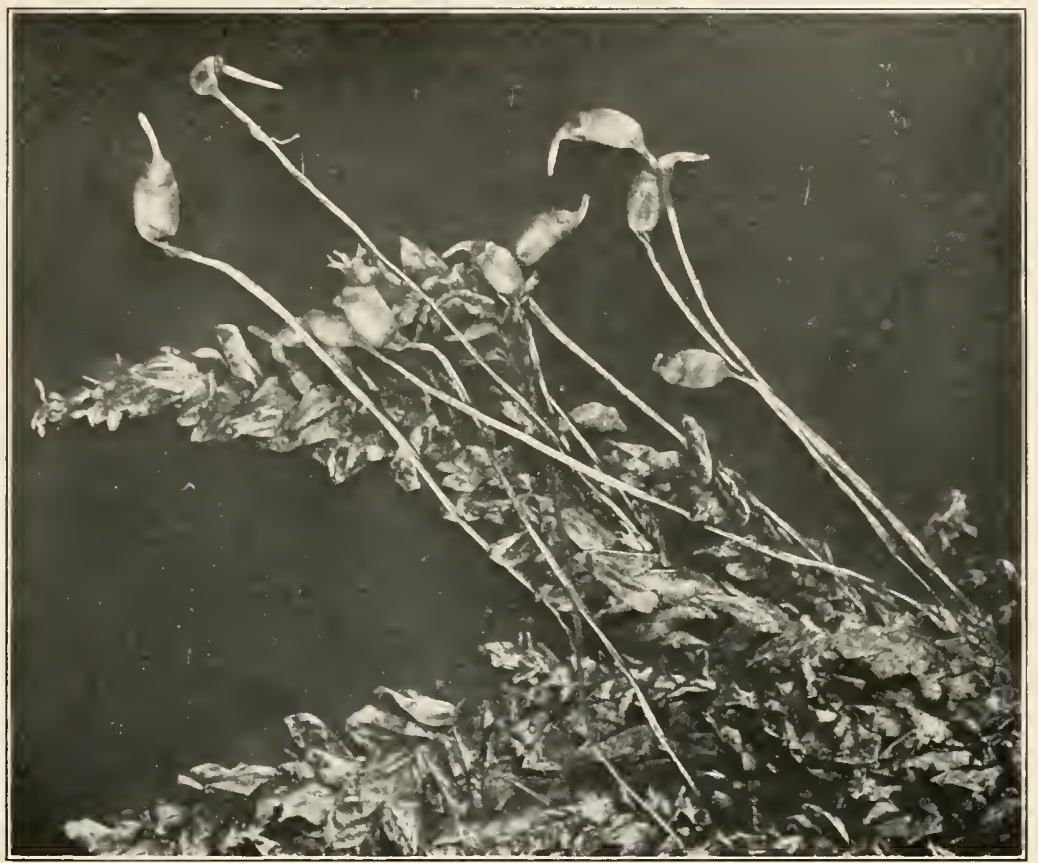

Eurhynchium rusciforme $\times 5$. From herbarium specimens. 

Plate Xi.

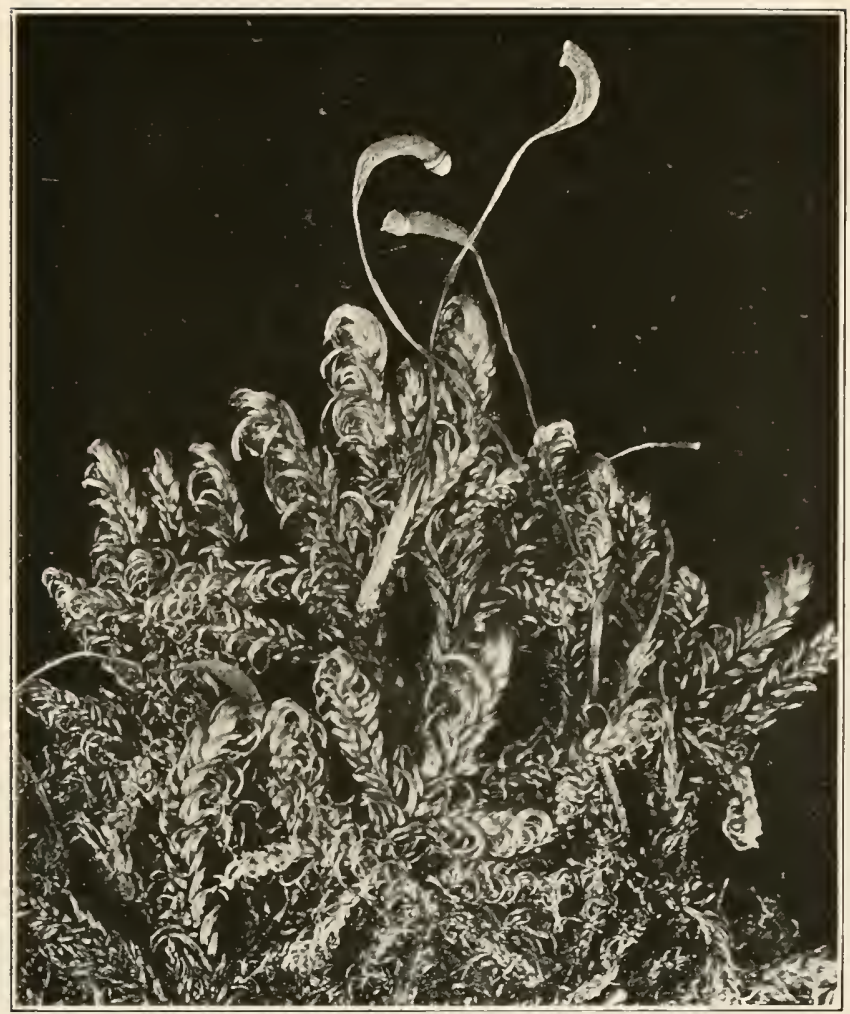

Drepanocladus uncinatus $\times 5$. From herbarium specimens. 

Plate Nil.
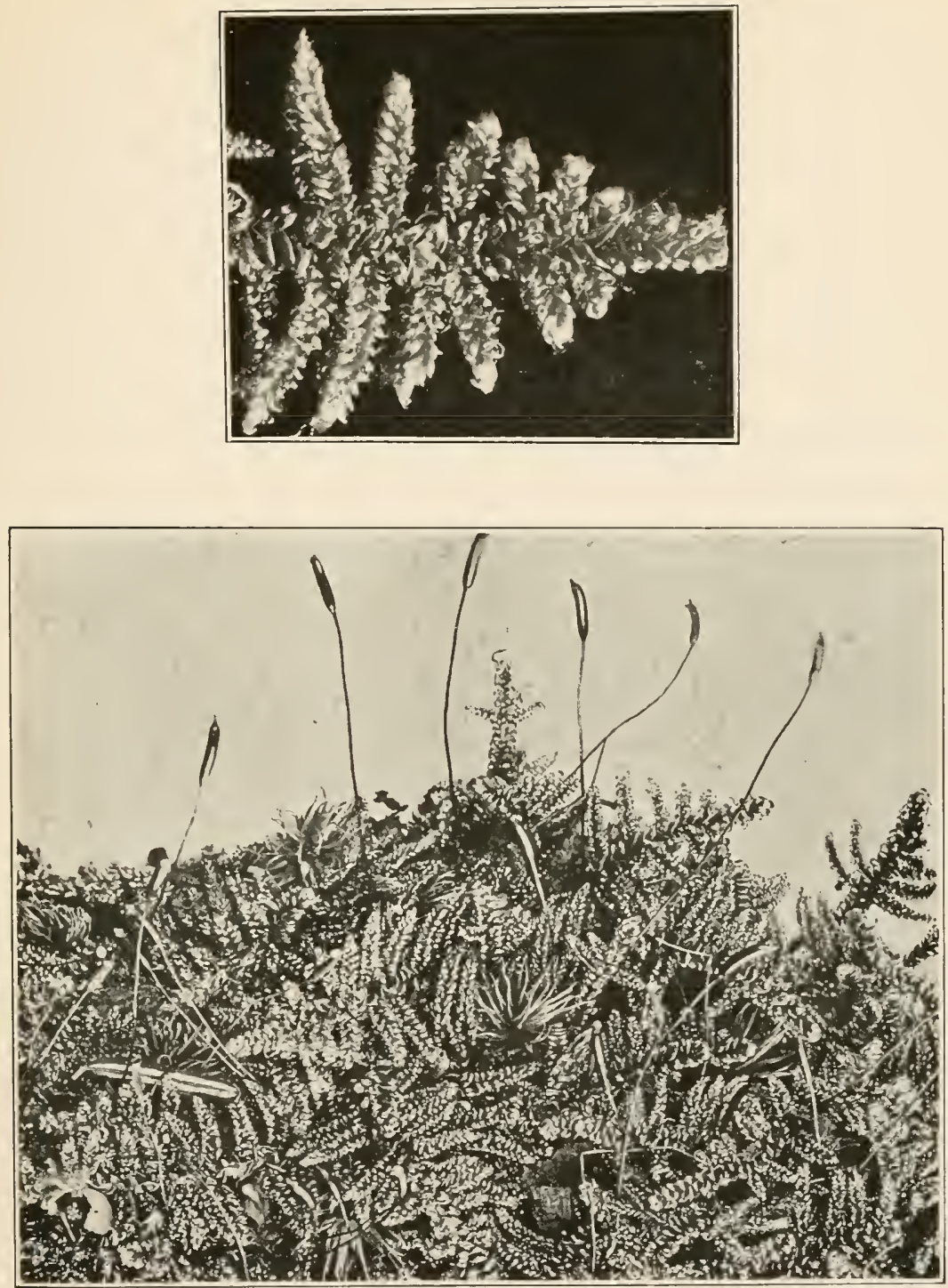

Hypum imponens $\times 2$. Above is a single spray $\times 7$ 




\section{INDEX TO GENERA}

Acaulon................ 60

Amblystegiella............. I09

Amblystegium............ 93

Amphidium............. 50

Anacamptodon............ I I 3

Andreaea.............. I6

Anomodon............. 78

Aphanorrhegma........... 56

Archidium............... 2 I

Astomum............. 4I

Aulacomnium........... 6 I

Barbula................ 43

Bartramia.............. 63

Brachythecium........... 84

Bruchia............... 23

Bryhnia................. 88

Bryum.............66, I 19

Buxbaumia............. 20

Calliergon................ 99

Camptothecium........... 88

Campylium.............. 96

Campylostelium.......... 37

Catharinea............. I9

Ceratodon.............. 25

Cirriphyllum............. 89

Claopodium.................. 76

Clasmatodon. . . . . . . . . . I I I4

Climacium............. 9

Cryphea............. I I 5

Desmatodon............ 46

Dichelyma.............. I I 7

Dichodontium........... 27

Dicranella................ 28

Dicranum............ 30, I I9

Didymodon............. 44

Ditrichum............... 25

Drepanocladus............ 97

Drummondia............ 5I

Encalypta........... 48, I I9

Entodon................ I Io

Ephemerum............. 58

Eurhynchium........... 89
Fabronia............... II 4

Fissidens........... 33, I I9

Fontinalis............. I I 7

Forsstroemia............. I I 5

Funaria............. 57

Georgia.............. I 7

Grimmia.............. 37

Gymnostomum.......... 42

Hedwigia............... 36

Homalia............... I I 6

Homalotheciella.......... 90

Hylocomium............. 82

Hygrohypnum............ IOI

Hyophila............... 46

Hypnum............... 103

Leptobryum............... 65

Leskea........................... 76

Lindbergia............. 77

Leucobryum............. 32

Leucodon............... I I 4

Meesea................. 60

Mniobryum............. 66

Mnium............... 70

Myurella............. 80

Nanomitrium............. $5^{6}$

Neckera................ I I 8

Oncophorus............. 28

Oreoweisia............. 27

Orthotrichum.......... 52

Phascum............. 4I

Philonotis............... 62

Physcomitrium........... 56

Plagiothecium........... 106

Platygyrium............ I I 2

Pleuridium............. 23

Pogonatum.............. I9

Pohlia................. 65

Polytrichum............ I7

Porotrichum............. 92

Pottia............... 45 
Pterigynandrum.

Tetraplodon............. 55

Ptychomitrium.......... 37

Thelia................ 79

Pylaisia.............. II 2

Raphidostegium.

Thuidium............ 74

Rhabdoweisia. .

Timmia............... 6i

Rhacomitrium........... 39

Tortella.............. 45

Rhodobryum............ 70

Tortula............... 47

Rhytidium............ 83

Saelania............... 25

Sciaromium.............. 96

Seligeria............... 26

Trematodon............. 28

Trichostomum........... 44

Ulota.............. $5 \mathrm{I}$

Sphagnum............ II

Webera............... 20

IVeisia .............. 42

Splachnum............. 55 


\section{BOOKS FOR SALE}

\section{By A. J. Grout, New Dorp, Richmond Co., New York.}

Mosses with Hand-lens and Microscope, bound in cloth, $\$ 7.00$, in half leather, \$7.50. 8 X II inches, 416 pages, 88 full-page plates and 265 figures in the text. Printed by McFarland on the best coated paper.

"Must be considered the most important work that has yet been published on American mosses. No other book will be needed by any moss student except the specialist." John Macoun.

Mosses with a Hand-lens (224 pp., 8vo, copiously illustrated) is a smaller book describing 250 mosses and 50 hepatics that can be identified by means of the Hand-lens alone. Specially adapted for beginners. \$I.75.

"I . . . take this opportunity to tell you how satisfactory I find your book introducing students to the taxonomy of the Bryophytes." Prof. Lincoln Wr. Riddle, Wellesley College.

Loeske, Studien sur vergleichenden Morphologie............ \$1.50

Cavers, Inter-relationships of the Bryophyta ............. I.50

McVicar, Student's Handbook of British Hepatics............. 5.00

Gray's Plantae IVrightianae...................... 3.00

Report of the State Botanist of New York, 1895, '96, '97, '98, '99.... Vasey's Grasses of the Pacific Slope (Pts. I and II, Bull. No. I3, U. S.

Dept. Agriculture)........................ 3.00

Grasses of the Southwest, by Vasey, (Bull. No. 12, U. S. Dept. Agri-

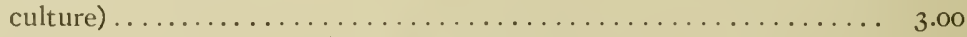

Botany of The Death Valley ixpedition, by F. V. Coville (Vol. IV,

Contributions from U. S. National Museum, I893).......... 3.00

Fern Bulletin, Vols. VII to XIX incl................. 9.00

Torreya. Vols. I-to date. Per vol................... I.00

Fresh IVater Rhizopods, by Leidy.................... 5.00

Lesquereux and James' Manual North America Mosses........... 7.00

Barnes and Heald, Keys to N. A. Mosses................. 2.00

Supplement to Index Bryologicus, by Paris................ 1.00

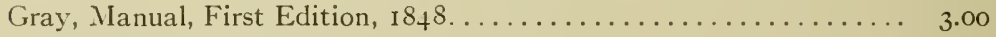

Gray, School and Field Book of Botany.................. 75

Gray, Manual, 6th Ed.................................. 1.00

Britton, Manual of N. E. States and Canada, Ist Ed........... 2.00

Britten, European Ferns....................... 3.50

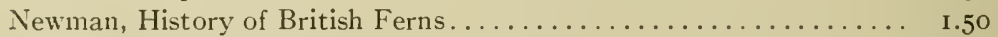

Druery, Book of British Ferns..................... I.00

Cooke, Handbook of British Hepaticae................. 1.50

Grout, List of Vt. Mosses with Suppl................... .15

Grout, Illustrated Glossary of Bryological Terms.............. . Io

Small, Flora of S. Eastern U. S., Ist Ed............... 3.50

U. S. Geological and Geographical Survey of Colorado, Wyoming, etc.,

I 3 Vols. complete.......................... 10.00 
Audubon, Quadrupeds of $N$. America, Pts. I and 16, each.......... 2.00

Pacific R. R. Reports complete, set of $\mathbf{r}_{3}$ Vols................ $\mathbf{8 5 . 0 0}$

American Botanist, Vols. I to 18 incl...................... 10.00

Natural History of N. Y., Botany by John Torrey. Vols. I and II with 162 colored Plates.............................. 10.00

Same, with Plates uncolored.................................

Nat. Hist. N. Y. Reptiles and Fishes. DeKay. 2 Vols. I02 Plates.. 7.00

Same, Molluscs and Crustacea. 53 Plates, some colored.......... 5.00

U. S. Geological Survey, W. of rooth Meridian. Vols. I 7 complete,

$\$ 2.75$ per volume. Lot........................... 12.00

U. S. Geological Survey of the Territories. Edited by Hayden-

Vol. 2, Cope, Vertebrata of Cretaceous.................... 5.00

Vol. 6 and 7. Lesquereux, Contributions to Fossil Flora,

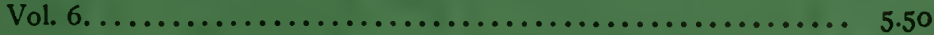

Vol. 7 ...................................... 4.50

Vol. 9. Meek, Invertebrate Cretaceous and Tertiary, etc........ 5.00

Vol. I1. Coues and Allen. N. Anr. Rodentia................ 5.00

Flora of Colorado, Porter and Coulter, Washington, $1874 \ldots \ldots \ldots \ldots$ r.oo

Preliminary Synopsis of N. Am. Carices, Bailey, Washington, 1886... 1.00

Grasses of the Arid Districts, Vasey. Dept. Agcl. Bull. No. 6, 1887... 1.00

Tuckerman, Synopsis N. Am. Lichens, Parts I and 2............ 15.00

Fink, Lichens of Minnesota, 8vo, 5 I full page Plates, mostly photo-

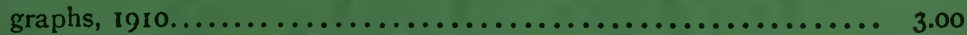

Farlow, Marine Algae of New England..................... 2.50

Science 1898 to date, price on application

Nouvelle Flore Francais, Gillet \& Magne $1887 \ldots \ldots \ldots \ldots \ldots \ldots \ldots \ldots \ldots$

Apgar, Trees of N. Am.............................. $\quad{ }^{7} 75$

Odd numbers and complete volumes of Fern Bulletin, Plant World, Mycological Bulletin, Muhlenbergia, Bartonia, Bot. Gaz. (running from Vol. 12 to Vol. 52, Bulletin. Torrey Bot. Club, and practically every American botanical publication. Will also buy and exchange any American botanical publication. Prices on application.

Nearly complete set of Contributions from the U.S. Nat. Herbarium-

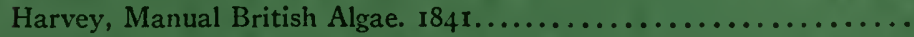

Barnes, Analytical Keys to Gen. and Species of Mosses, Earliest Edi-

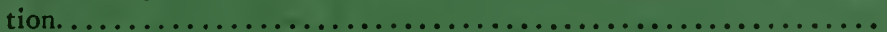

Bull. N. Y. Bot. Gardens, Nos. I-17, 5 Vols. complete ( $\$ 3.00$ per vol.).. 12.00

Farlow, Provisional Host Index, as published................ 5.00

Evans and Nichols, Bryophytes of Ct...................... $\quad .30$

Lett, Hepaticae of British Isles...................... 2.50

Descriptions of some New Species of N. Am. Mosses by Leo Lesquereux and T. P. James with supplement by W. P. Schimper. Proc. Am. Acad. Presented Feb., 1869. Rare and difficult to obtain. 9 pp., I 7 species descr..................................... 


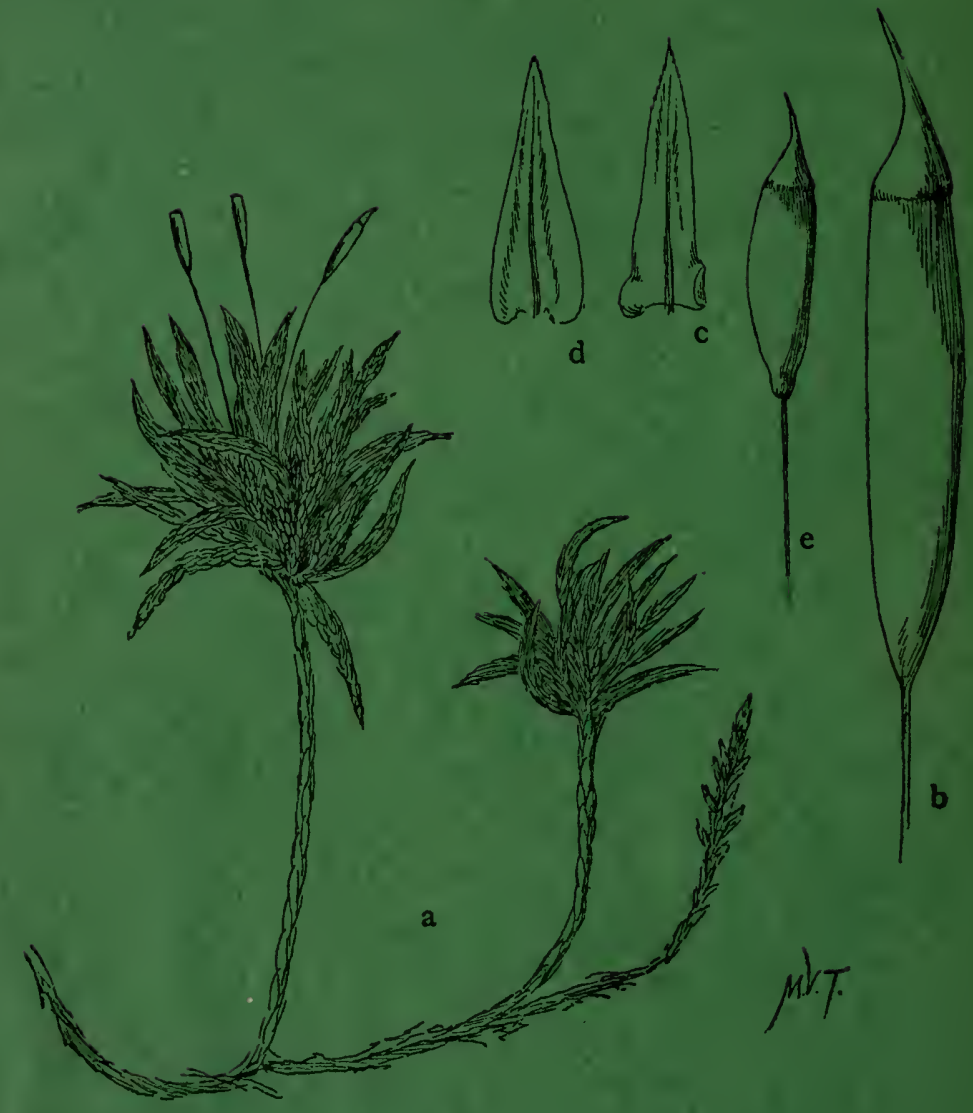



New York Botanical Garden Library

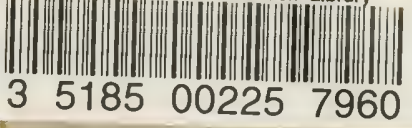


